\title{
STRATIGRAPHY, SEDIMENTOLOGY AND DIAGENESIS OF THE LINDSAY FORMATION, UPPER ORDOVICIAN, OTTAWA EMBAYMENT, EASTERN ONTARIO
}

by

\section{RUTH GBADEYAN}

A thesis submitted to the Faculty of Graduate and Postdoctoral Affairs in partial fulfillment of the requirements for the degree of

Master of Science

in

Earth Sciences

Carleton University

Ottawa, Ontario

(C) 2011, Ruth Gbadeyan 
THS

M.se.

2011

G33 


\section{ABSTRACT}

The Lindsay Formation (Upper Ordovician) of the Ottawa Embayment (eastern Ontario) represents the final stage of foreland carbonate platform development related to Taconic orogenesis along eastern Laurentia. The Lindsay Formation forms the upper unit of the regional Ottawa Group that underlies eastern Ontario. Available biostratigraphy (macrofauna, conodonts) indicates that the Lindsay is Edenian to Maysvillian in age, $\sim 453-452 \mathrm{Ma}$. The formation is divided into two members: the lower, newly defined, Nepean Point Member, and the upper Eastview Member, and conformably overlies the Verulam Formation. The Nepean Point Member is composed of highly bioturbated, nodular, fine to coarse grained, thin to thick, highly fossiliferous limestone beds with very thin discontinuous beds and laminae of calcareous shale. In contrast, the Eastview Member consists of sparsely fossiliferous lime mudstone and dark brown to black organic-rich calcareous to non-calcareous shale. Thin layers of densely compacted skeletal rudstones occur within the shale and cap some of the limestone beds. This unit underlies with apparent conformity deep-water shale of the Billings Formation.

Eight lithofacies are defined for the Lindsay Formation: Five carbonate (C1-C5) lithofacies indicate deposition in a shallow $(<50 \mathrm{~m})$ ramp environment, and three siliciclastic (S1-S3) lithofacies represent deeper ramp deposition. Facies within the Lindsay Formation are characterized by a bryonoderm grain-type association that represents the predominance of brachiopods, crinoids, bryozoans, and mollusks, without grain types (ooids, micrite and aggregate grains) otherwise typical of warm-water conditions. This might indicate a cool-water environment, but there are fragments of the 
dasycladacean algae, Vermiporella sp., that require warm water conditions. The lack of other supporting evidence for temperate carbonate deposition suggests that other environmental factors such as salinity or local shoal development may have played an important role in the distribution of grain types and water temperature. The Eastview Member defines an environment in which there was alternating influx of shale, and episodic concentrations of skeletal material. The latter represents concentration lags related to low sedimentation rates. The shale-limestone stratigraphy of this unit likely reflects oceanographic controls superimposed on increased rates of platform subsidence.

Diagenetic alteration of the Lindsay Formation records marine through deep-burial realms. The marine phase includes bioturbation, micritized skeletal material, microbial encrustation, and fragmentation of skeletal material. Shallow-burial alteration includes non-ferroan calcite overgrowth cementation, which arrested mechanical compaction, then dissolution of aragonitic allochems. Fractures and ferroan void-fill calcite cement, then formation of horizontal (burial) stylolites complete deeper burial alteration. Carbon and oxygen isotopes of the cements support a shallow- to deep-burial transition. Sub-vertical stylolites record a following history of lateral compression, likely related to faults, but the specific timing remains unknown. Fe-poor zoned (CL) dolomite occurs scattered throughout the host limestone, and are overgrown by a relatively more abundant microzoned (ferroan, no CL) dolomite. Dolomite occurs in burrows, along stylolites and within secondary porosity paleocavities. The predominant dolomite is reflected isotopically to be of deep-burial origin. The early dolomite was not characterized isotopically, but its paragenesis suggests a complicated shallow-burial origin. 


\section{ACKNOWLEDGEMENTS}

This research work was funded by a research grant from the Natural Sciences and Engineering Council to my supervisor. I am heartily thankful to my supervisor, Prof. George. R. Dix for his guidance, encouragement, valuable suggestions and patience which have propelled me to the successful completion of this thesis work.

I extend my appreciation to the Geological Survey of Canada (GSC) for providing me with the cores I examined during this research work. Also, I am grateful for the access given to me by some quarry owners and the opportunity to sample some rocks used in this research. To all the Faculty, staff members and students of the Earth Sciences Department, Carleton University, thank you.

I owe my deepest gratitude to my parents, Prof. and Mrs. Jacob Gbadeyan and my siblings: Grace, Rhoda, Ayo and Tanitoluwa. Your unconditional love, unwavering support and care have been priceless. I love you guys.

To my friends, you have been great. I am indebted to my colleagues; Uncle Sulaiman, Jeff, Odette and Ulan, your insightful discussions assisted me at different stages. I would also like to thank my extended family the Mbagwu's and the Adedoyin's for their constant encouragement, prayers and care. To everyone who contributed in one way or the other towards the successful completion of this research work, you have been invaluable. I am so grateful. God bless you all. Above all, I am grateful to the Lord Jesus Christ for for His faithfulness, grace and mercy. 


\section{TABLE OF CONTENTS}

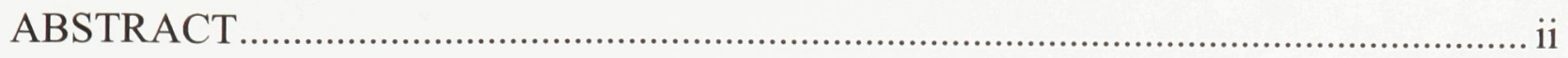

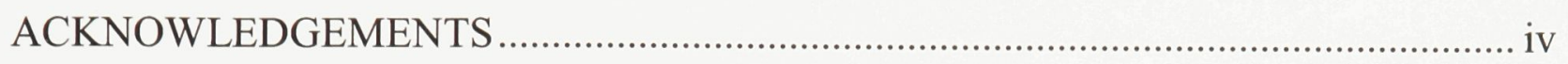

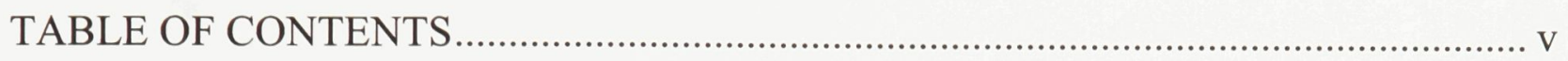

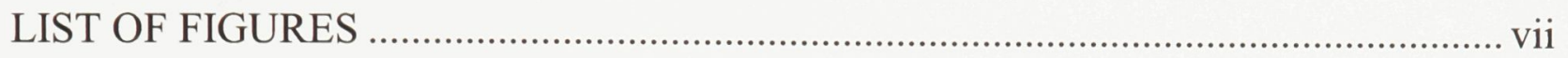

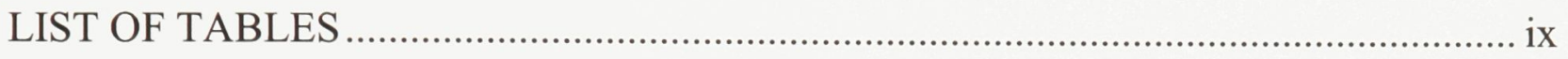

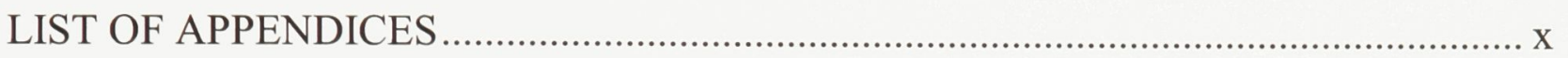

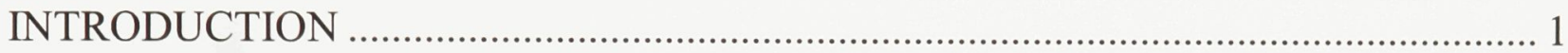

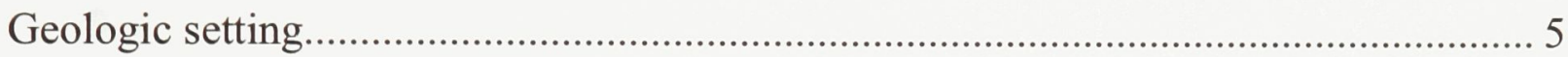

The St. Lawrence Platform ............................................................................. 5

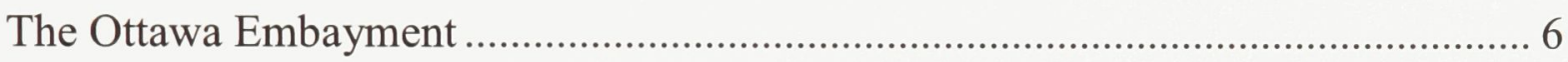

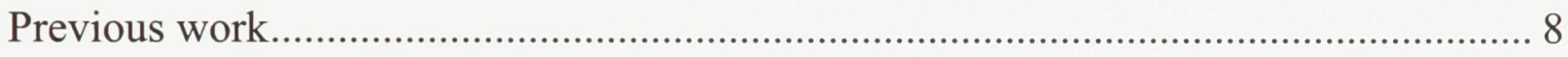

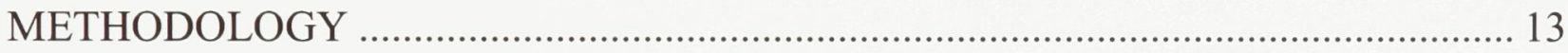

STRATIGRAPHY OF THE LINDSAY FORMATION ........................................... 15

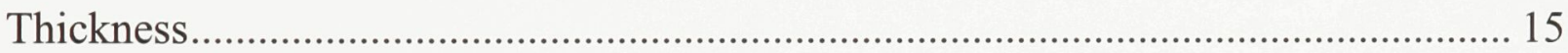

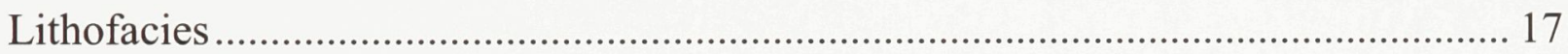

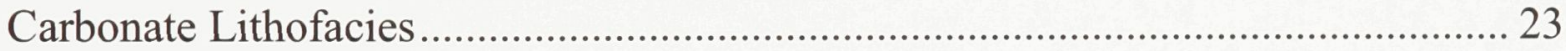

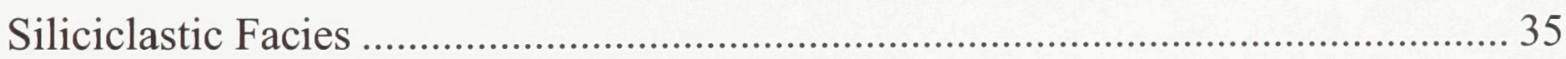

Regional Intraformational Correlation, eastern Ontario ..................................... 41

Chemostratigraphy $(\mathrm{C}, \mathrm{O}$-isotopes) of the Lindsay Formation................................ 45

DIAGENESIS AND GEOCHEMISTRY …...................................................... 48

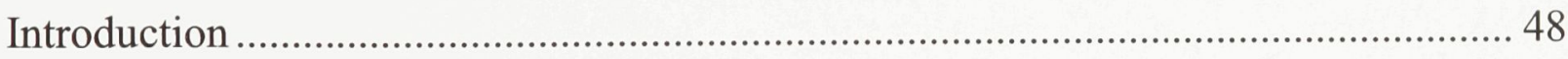

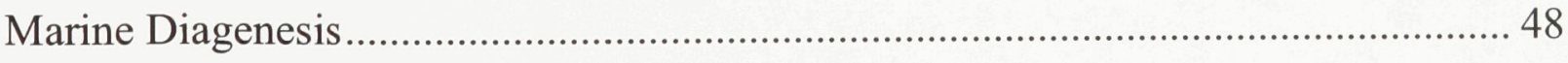

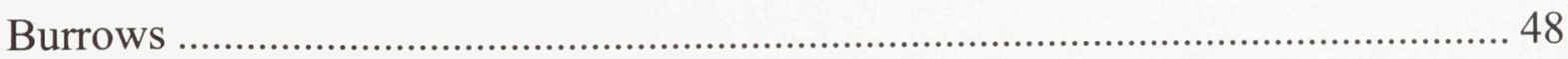

Micritized and Micritic Layers Related to Skeletal Material ................................ 51

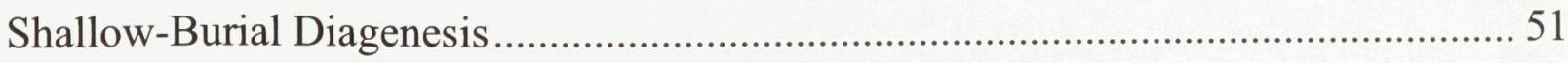

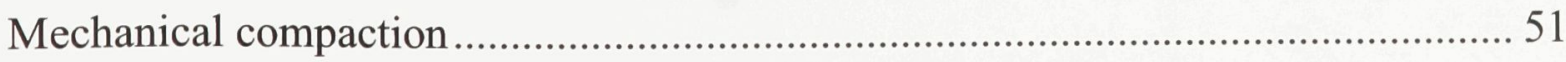




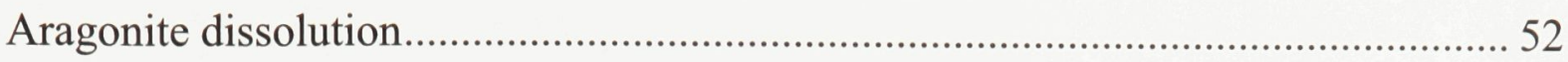

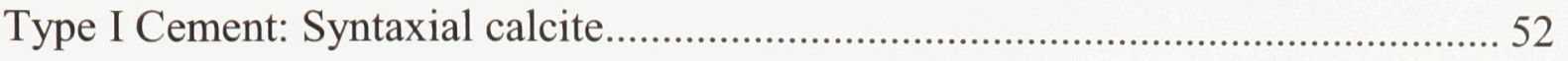

Type II Cement: Void-fill equigranular calcite …….................................................. 53

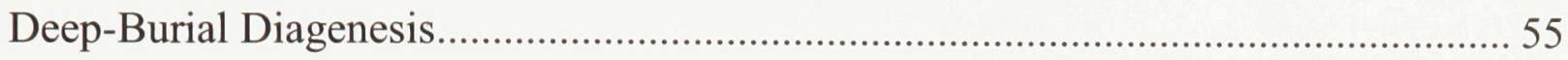

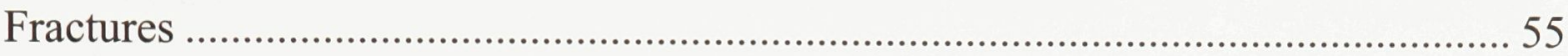

Type III Cement: Blocky equigranular calcite ………………………………...... 55

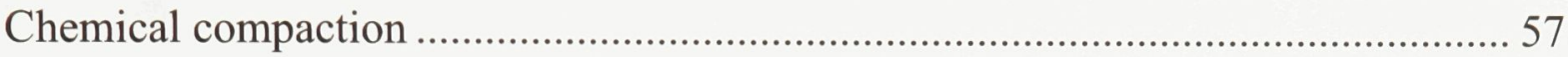

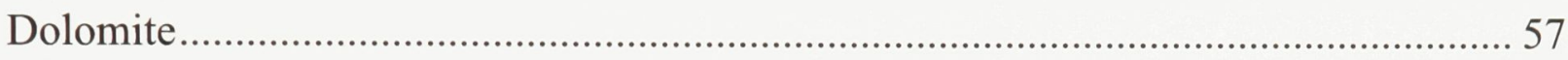

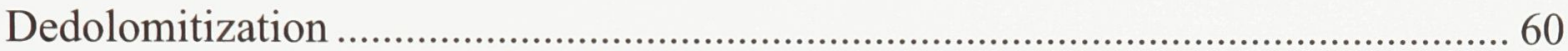

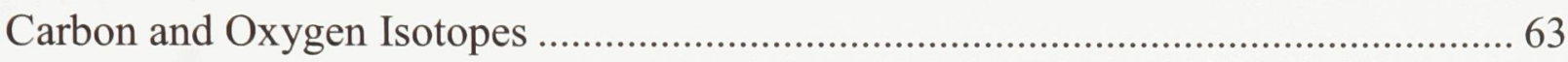

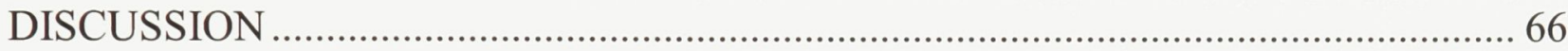

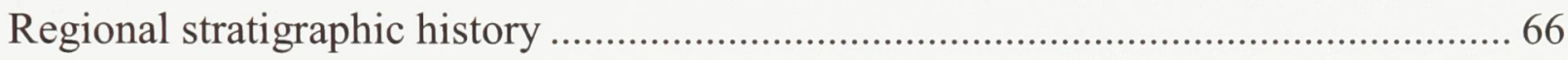

Paleoenvironmental considerations of the Lindsay Formation ...................................... 71

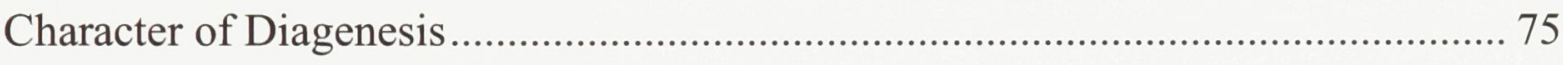

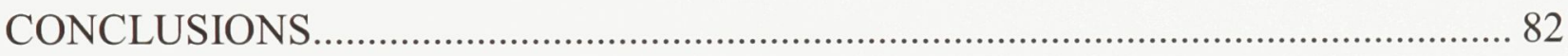

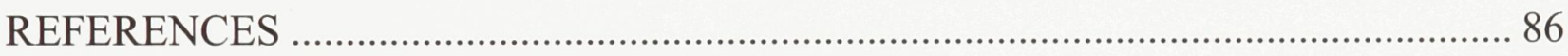

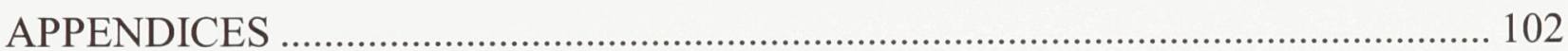




\section{LIST OF FIGURES}

Figure 1. Study locations within the city of Ottawa.

Figure 2. Locations of study area. Map showing studied localities A to L in southern and eastern Ontario.

Figure 3. General bedrock geology of southeastern Ontario and study area. Distribution of Paleozoic and Precambrian rocks and studied localities in eastern and southern Ontario

Figure 4. General stratigraphy of eastern Ontario (Ottawa Embayment) …...................... 7

Figure 5. History of stratigraphic nomenclature for the Upper Ordovician rocks in Ottawa Embayment, Quebec and New York.

Figure 6. The Lindsay and Billings Formations of southeastern Ontario, and their equivalents in south-central Ontario.

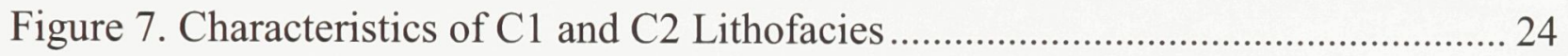

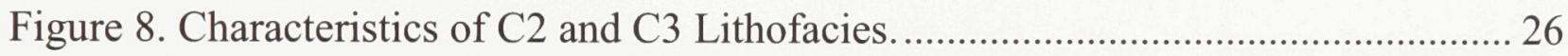

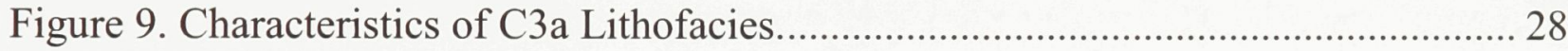

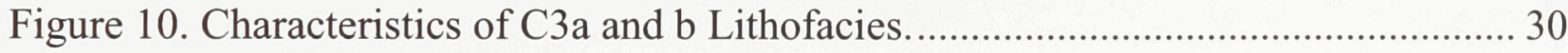

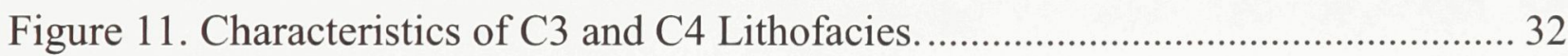

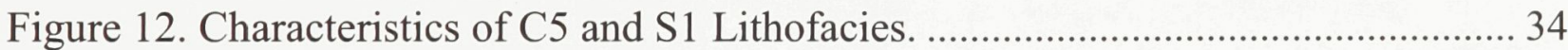

Figure 13. X- ray diffractogram of shale showing the major components (sample from

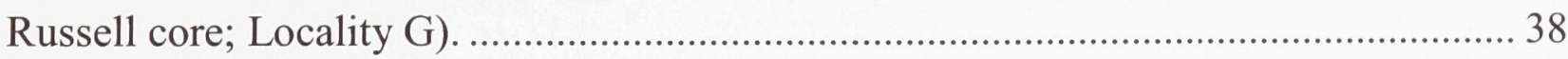

Figure 14. X-ray diffractogram of shale showing the major components (sample from St.

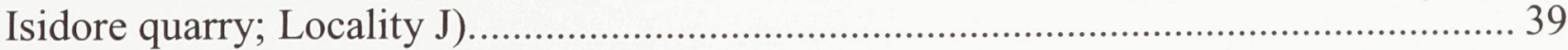

Figure 15. X-ray diffractogram of shale showing the major components (sample from

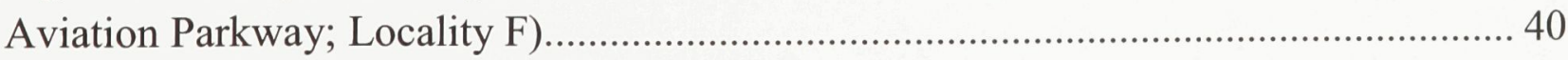


Figure 16. Stratigraphic columns of Localities $\mathrm{C}$ to $\mathrm{L}$, showing the distribution of lithofacies and lateral facies changes across eastern Ontario.

Figure 17. Showing the correlation of the upper (Eastview) Member in eastern Ontario. Localities E, F \& G. 44

Figure 18. The carbon and oxygen isotopes in the micritic facies of the Lindsay Formation. Localities G \& F. 46

Figure 19. Marine and shallow-burial diagenetic features............................................. 50

Figure 20. Shallow and deep burial diagenetic features.................................................. 54

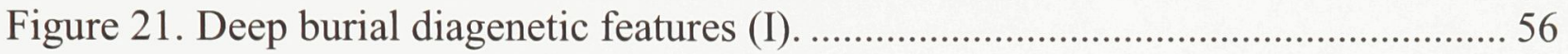

Figure 22. Showing the increasing values of the content of $\mathrm{FeO}(\mathrm{wt} \%)$ through a transect in the dolomite rhomb from core to outermost rim.......................................................... 59

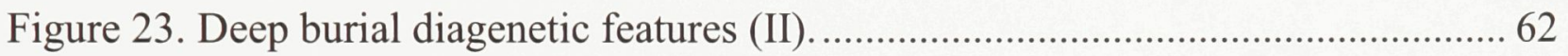

Figure 24. Carbon and oxygen isotope values of cement Type III, a mixture of cement Type II and III, Ordovician brachiopods (Shields et al. 2003) and dolomite................... 64

Figure 25. Caradocian and Ashgillian strata of northeastern North America. Formational

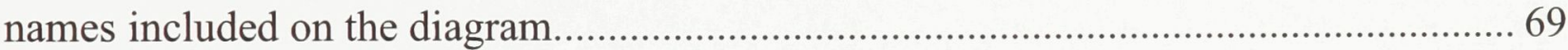

Figure 26. $\delta^{18} \mathrm{O}$ calcite versus temperature (After Land 1983)....................................... 78

Figure 27. $\delta^{18} \mathrm{O}$ calcite versus temperature for various $\delta^{18} \mathrm{O}$ values. After Land $1983 \ldots 80$

Figure 28. Photograph showing nodular, bioturbated, and fine to coarse-grained limestone with very thin laminae of calcareous shale of the Nepean Point Member at the National Art Gallery 104 


\section{LIST OF TABLES}

Table 1. Approximate stratigraphic thicknesses of the Lindsay Formation. 16

Table 2. Attributes of carbonate (C-) and siliciclastic (S-) lithofacies of the Lindsay Formation 18

Table 3. Sequence of diagenetic events as interpreted from petrographic studies of the Lindsay Formation. 


\section{LIST OF APPENDICES}

Appendix I: New stratigraphic nomenclature ................................................. 102

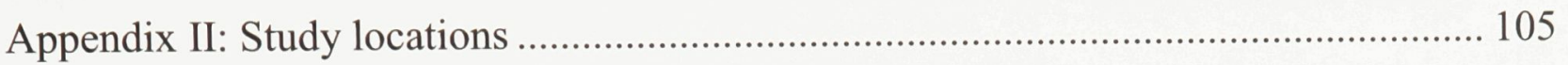

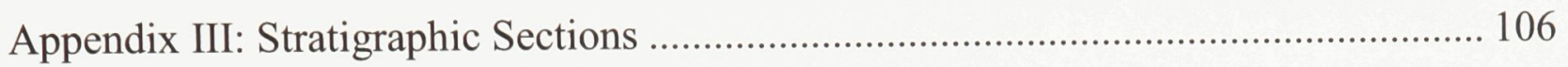

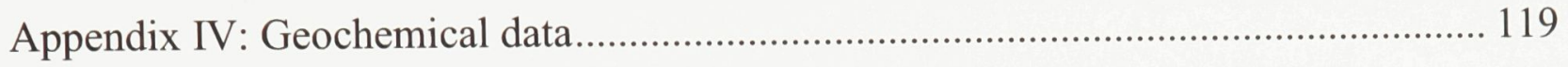




\section{INTRODUCTION}

The Upper Ordovician (Edenian to Maysvillian) Lindsay Formation represents the last stage of carbonate platform development, represented by the regional Ottawa Group, within the Taconic foreland basin succession as preserved in the Ottawa Embayment, eastern Ontario. The Lindsay Formation contains evidence of a significant transition in sedimentation coincident with increased regional subsidence linked to Taconic orogenesis that resulted in foundering of the carbonate platform and burial beneath marine siliciclastics transported westward from the evolving Taconic orogen (Hiscott 1984). The transition defines transformation of a once relatively stable foreland carbonate platform consisting of fine- to coarse-grained carbonates to deposition into a prominent succession of interbedded organic-rich shale and limestone as defined by the previously named Eastview Member (Wilson 1946; Williams 1991).

The Lindsay Formation is a name transported from central Ontario to establish a lithostratigraphic unit that encompasses part of the previous faunally defined Cobourg Formation (and prior Picton Formation) (Raymond 1921; Foerste 1924; Kay 1937; Wilson 1946; Liberty 1967; Williams 1991). Despite a lot of previous paleontological work, the rocks in eastern Ontario represented by the Lindsay Formation have been described only in general terms of sedimentology, depositional facies, and little to no description of diagenesis.

My study is presented in three sections: (1) local to regional stratigraphy and lithofacies of the Lindsay Formation in eastern Ontario based on core and outcrop sections (Figures 1-3); (2) carbonate diagenesis; and (3) a discussion of these components and how they 
Page Facing 2

Figure 1. Study locations within the city of Ottawa. Abbreviations: C-National Art Gallery outcrop; D-Mint section outcrop; E-Billings Bridge core and F-Aviation Parkway outcrop (where $\bullet$ represents outcrop localities and $\star$ represents core localities). 


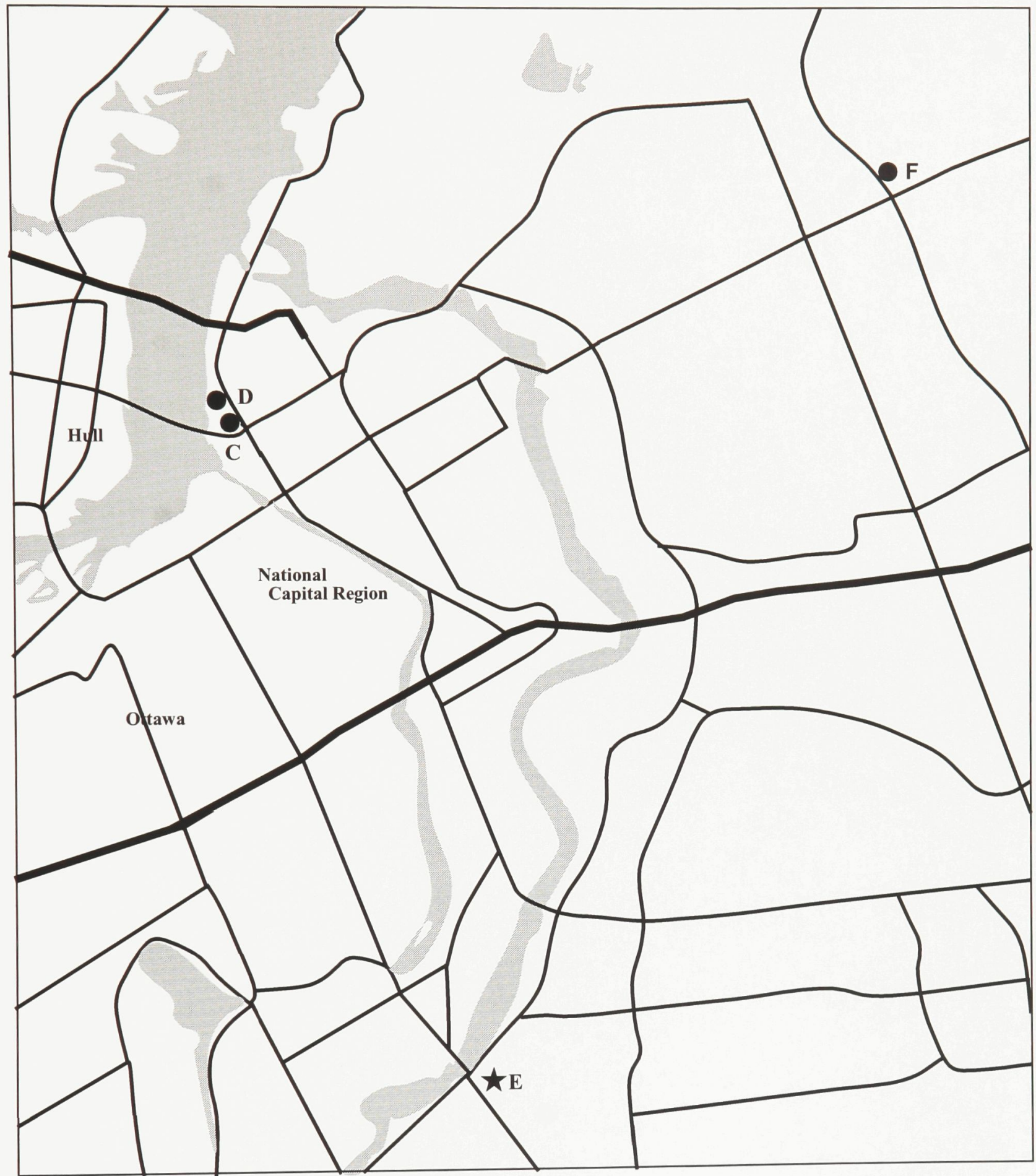


Page Facing 3

Figure 2. Locations of study area. Map showing studied localities A to L in southern and eastern Ontario. Location bordered by dashed box denotes area shown in Figure 1. Localities in the city of Ottawa (area in the box) are shown in Figure 1. (A \& BBowmanville Core; G-Russell Core; H-Canaan Quarry; I-Navan Quarry; J-St. Isidore Quarry; K-Richier Quarry and L-Apple Hill Quarry). 


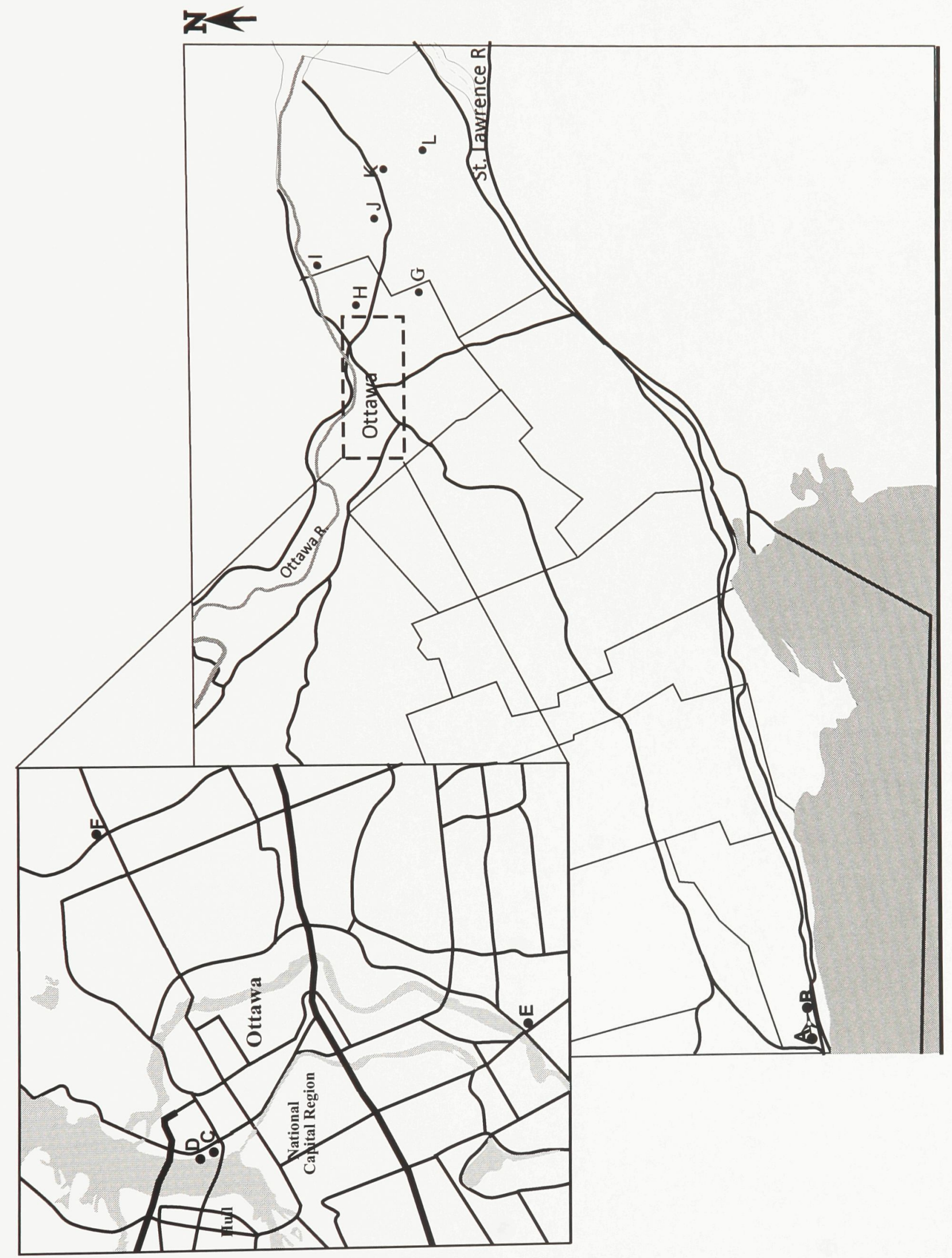


Page Facing 4

Figure 3. General bedrock geology of southeastern Ontario and study area. Distribution of Paleozoic and Precambrian rocks and studied localities in eastern and southern Ontario. Locality names are listed in Figures 1 and 2. 


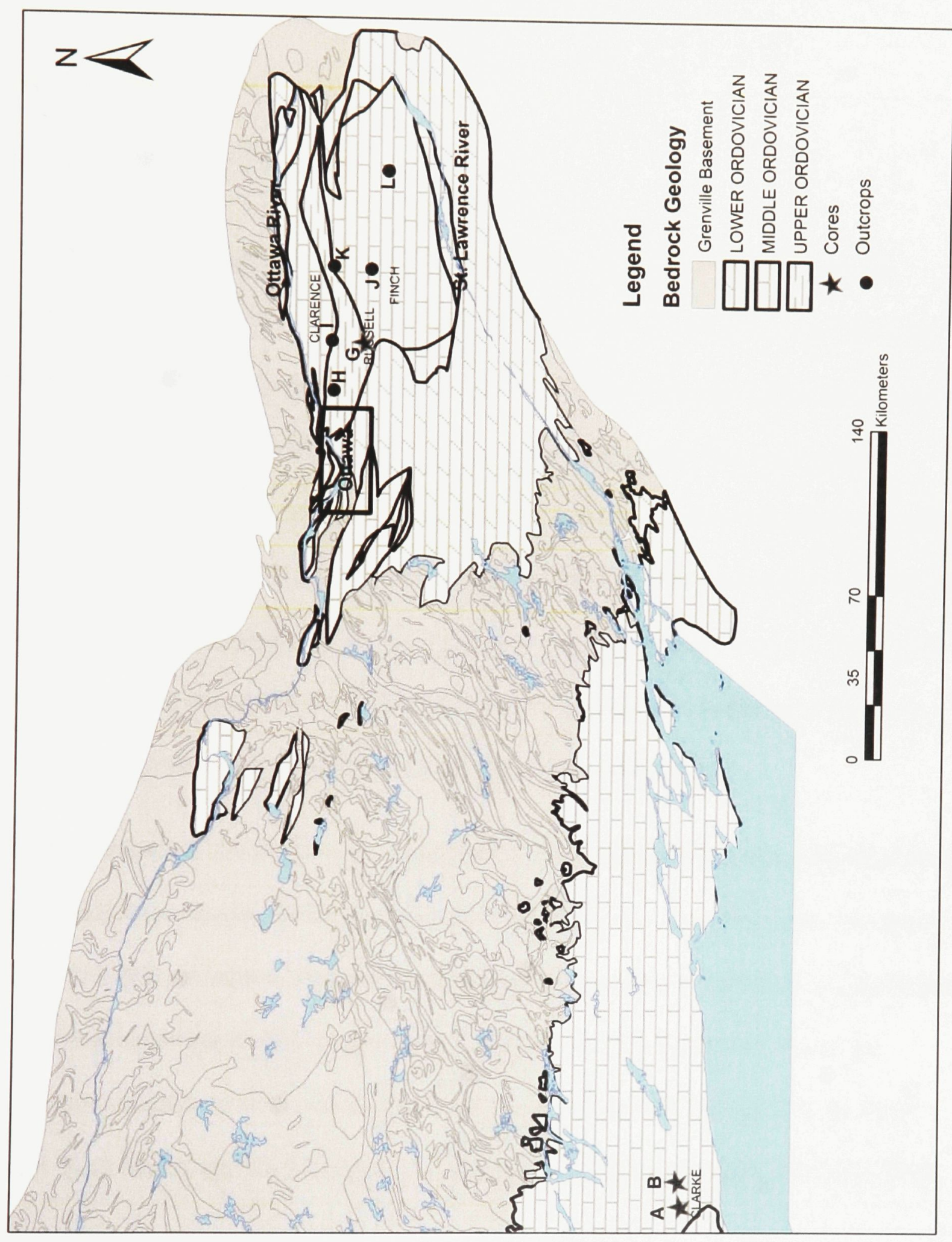


define platform development and its demise in response to Late Ordovician foreland basin tectonism along eastern Laurentia.

\section{Geologic setting}

\section{The St. Lawrence Platform}

The St. Lawrence Platform defines an epicontinental shelf underlain by CambroOrdovician strata along the Canadian portion of eastern Laurentia. The St. Lawrence Platform is underlain by Precambrian rocks of the Grenville orogen. The epicontinental platform contains the Sauk and Lower Tippecanoe Megasequences, stratigraphic succession that records regional sedimentation in response to plate-boundary tectonism. The Sauk Megasequence spans the late Precambrian to Middle Ordovician drift-rift phase of the Iapetus ocean basin; the Lower Tippecanoe Megasequence spans the Middle to Late Ordovician history of plate convergence, and is preserved in the local Taconian foreland succession that underlies eastern Ontario (Sanford 1993).

The eastern part of the St. Lawrence platform is caught up in the fold and thrust zones of the Appalachian orogen. The western limit of this tectonic zone occurs near Montreal (Sanford 1993). In eastern Ontario, the platform succession is autochthonous, preserved in the structural Ottawa Embayment that is bounded by Precambrian rocks of the Laurentian Highlands to the north (Quebec), the Adirondack Mountains to the south (New York State), and the Frontenac Arch along the western boundary (Wilson 1946). 


\section{The Ottawa Embayment}

The Ottawa Embayment underlies eastern Ontario, the western part of southern Quebec, and northern New York State. It forms a WNW-ESE oriented structural depression that cuts across the NE-SW structural grain of the Precambrian Grenville orogen (Sanford 1993). Its eastern border is defined by the Beauharnois Anticline, just west of Montreal. The Lower Paleozoic stratigraphy of the embayment represents a westward, platforminterior extension of the central St. Lawrence Platform.

The embayment is underlain by sedimentary rocks (Figure 4) ranging in age from Neoproterozoic to Late Ordovician (Wilson 1946; Williams 1991). The elongate shape of the Ottawa Embayment partially reflects uplifted and erosional margins of a Cambrian to Upper Ordovician sedimentary basin bordered by Precambrian highlands to the north, west, and south. Studies by Kay (1942) and Wilson (1946) mapped a large number of normal and likely strike-slip faults, with a tectonic geometry referred to by Kay (1942) as the Ottawa Bonnechère Graben. The fault system is the principal control of bedrock patterns within the study area (see Figure 3). Some of the faults appear to be deep-seated, possibly offsetting the Moho (Mereu et al. 1986).

This cratonic-scale structural corridor was interpreted to reflect Mesozoic reactivation of an underlying Late Proterozoic fault system, the failed arm of the Iapetan ocean basin structure (Kumarapeli and Saull 1966; Kumarapeli 1985). Steeply dipping normal faults with vertical displacement of $<1 \mathrm{~km}$ occur within the embayment (Wilson 1946; 
Figure 4. General stratigraphy of eastern Ontario (Ottawa Embayment). Thickness estimates based on the Russell core (Williams 1991). Modified after Dix and Al-Rodhan (2006). 


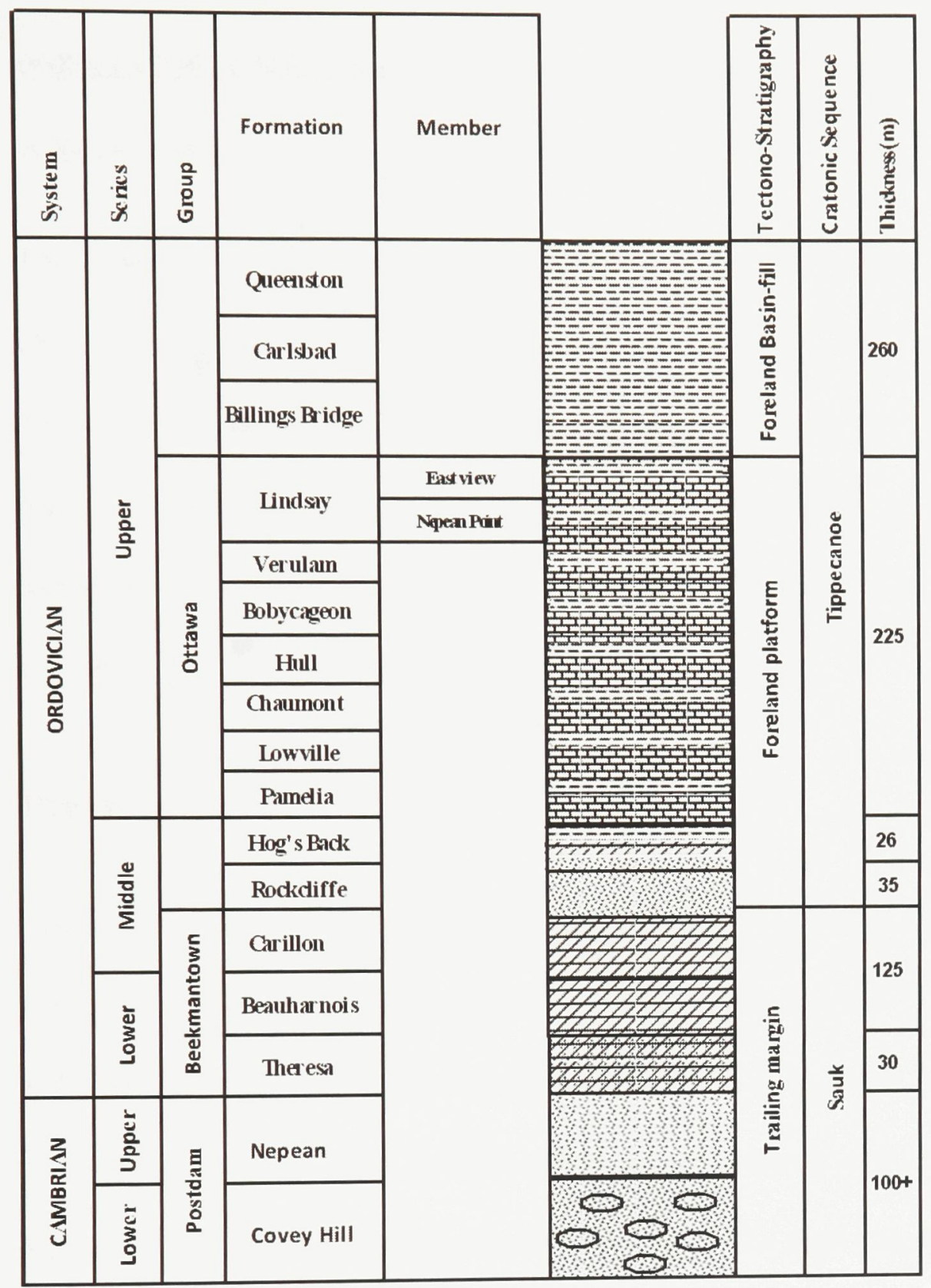

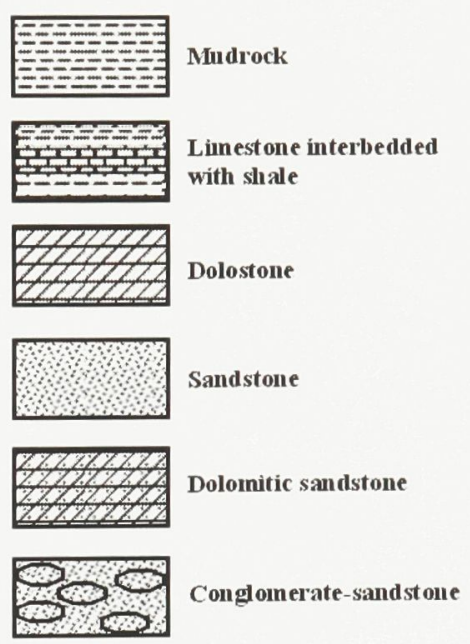


Williams 1991). Subsequent work, however, has shown that some faults are of synsedimentary (Middle Ordovician) age (Dix and Al Rodhan 2006).

The Upper Ordovician portion of basin fill within the Ottawa Embayment consists of the Ottawa Group carbonates that define a regional shallow-water platform and overlying deep-water shales (Billings, Carlsbad and Queenston Formations) that accumulated following regional foundering of the platform and progressive westward expansion of deep-water basins due to tectonic loading along the distal plate boundary (Sanford 1993; Figure 4).

\section{Previous work}

The Lower Paleozoic strata in the Ottawa Embayment have been studied for more than a century. In 1841, Sir William Logan began his exploration work along the Ottawa River. Subsequent workers (Murray 1852; Logan 1863; Cushing et al. 1910; Raymond 1912, 1914, 1921; Wilson 1932) all noticed a general similarity of stratigraphy in the vicinity of Kingston, Ottawa, and northern New York State. The first regional analysis of stratigraphic correlation encompassing these regions was that of Raymond (1912). Subsequent work of Wilson (1946) modified his formal stratigraphy based on very detailed analysis of macrofauna and creation of macrofaunal zones. The result of this was that the upper part of the carbonate platform succession in eastern Ontario was defined as the Cobourg Formation (Figure 5). Liberty (1967) in a GAC-MAC abstract was the first to suggest that Wilson's (1946) faunal zonation as the basis of formation definition 
Page Facing 9

Figure 5. History of stratigraphic nomenclature for the Upper Ordovician rocks in Ottawa Embayment, Quebec and New York. Shaded areas represent sections not studied. 


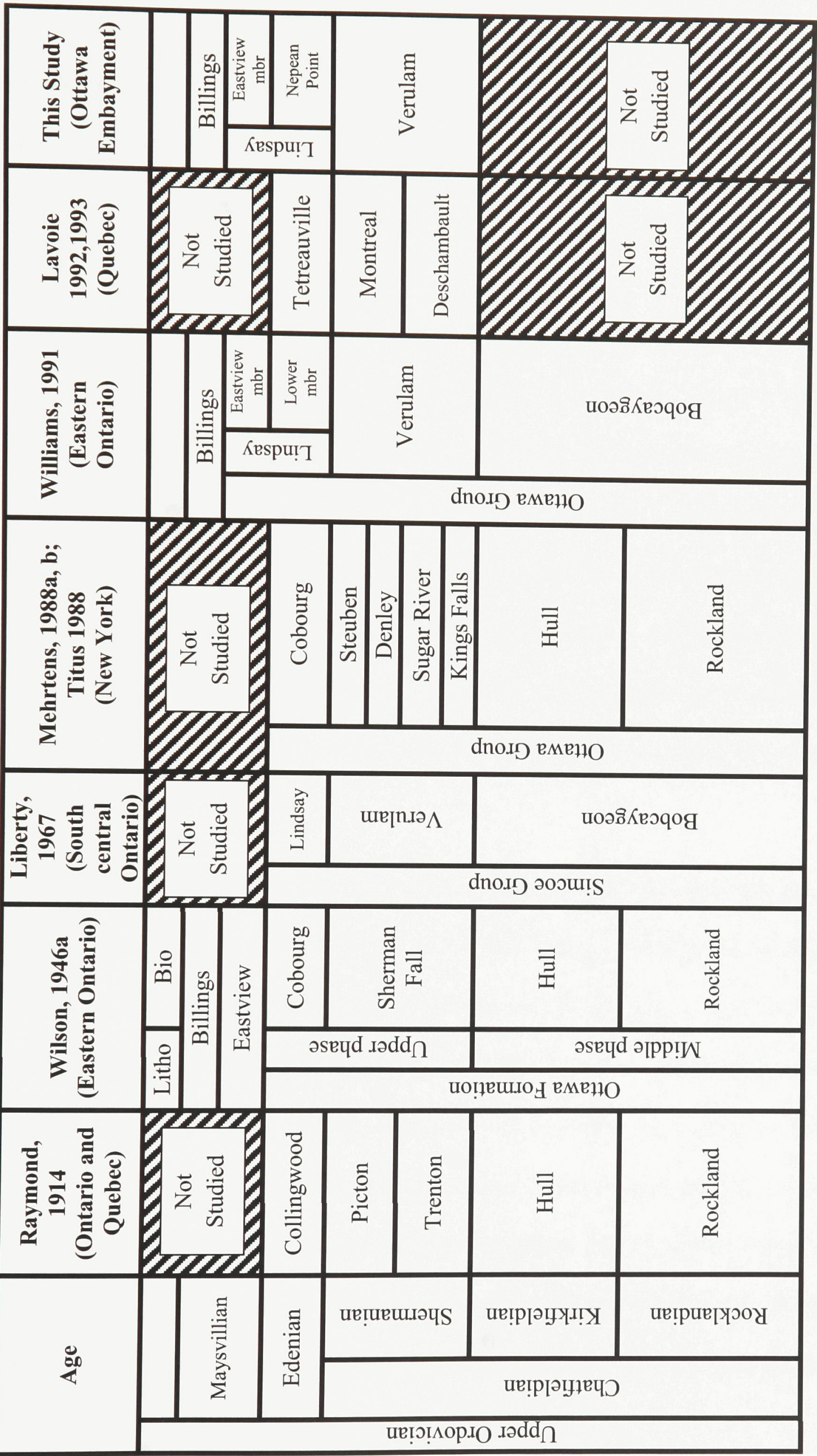


should be abandoned. Instead, he recommended adopting the lithostratigraphic nomenclature he would eventually establish for south-central Ontario (Lake Simcoe region) (Liberty 1969) on the basis of there being strong lithological similarity among areas in central Ontario, Kingston and Ottawa. This approach was further developed by Williams (1991) who divided the Lindsay Formation into an unnamed "lower member" and an upper Eastview Member. Following work by Russell and Telford (1983), the equivalent unit of the Eastview Member in central and southern Ontario is the Collingwood Member of the Lindsay Formation. For both the Eastview and Collingwood Members, from this previous work, the basal contact with the lower member of the Lindsay Formation is the appearance of black or organic-rich shale interbedded with limestone (Figure 6). The boundaries established by Russell and Telford (1983) can be compared to the Wilson (1946) and Williams (1991) contacts in the St. Lawrence Platform.

From this formation structure, therefore, the Lindsay Formation forms the uppermost unit of the Ottawa Group, and includes most of the Cobourg Formation. Thus, the lower contact of the Lindsay Formation is placed within the upper part of the Cobourg biostratigraphic zone (see Figure 5) and the upper contact of the Lindsay Formation is placed at the upper contact of the Eastview Member (Williams 1991). It gradationally overlies the Verulam Formation (its uppermost section containing the lower Cobourg interval) and underlies shale of the Billings Formation. The Verulam Formation consists of pale to blue grey, thin to medium bedded bioclastic packstone to grainstone and interbedded thin dark grey calcareous shale. The Billings Formation overlies the Lindsay 
Page Facing 11

Figure 6. The Lindsay and Billings Formations of southeastern Ontario, and their equivalents in south-central Ontario (modified from Williams 1991). 


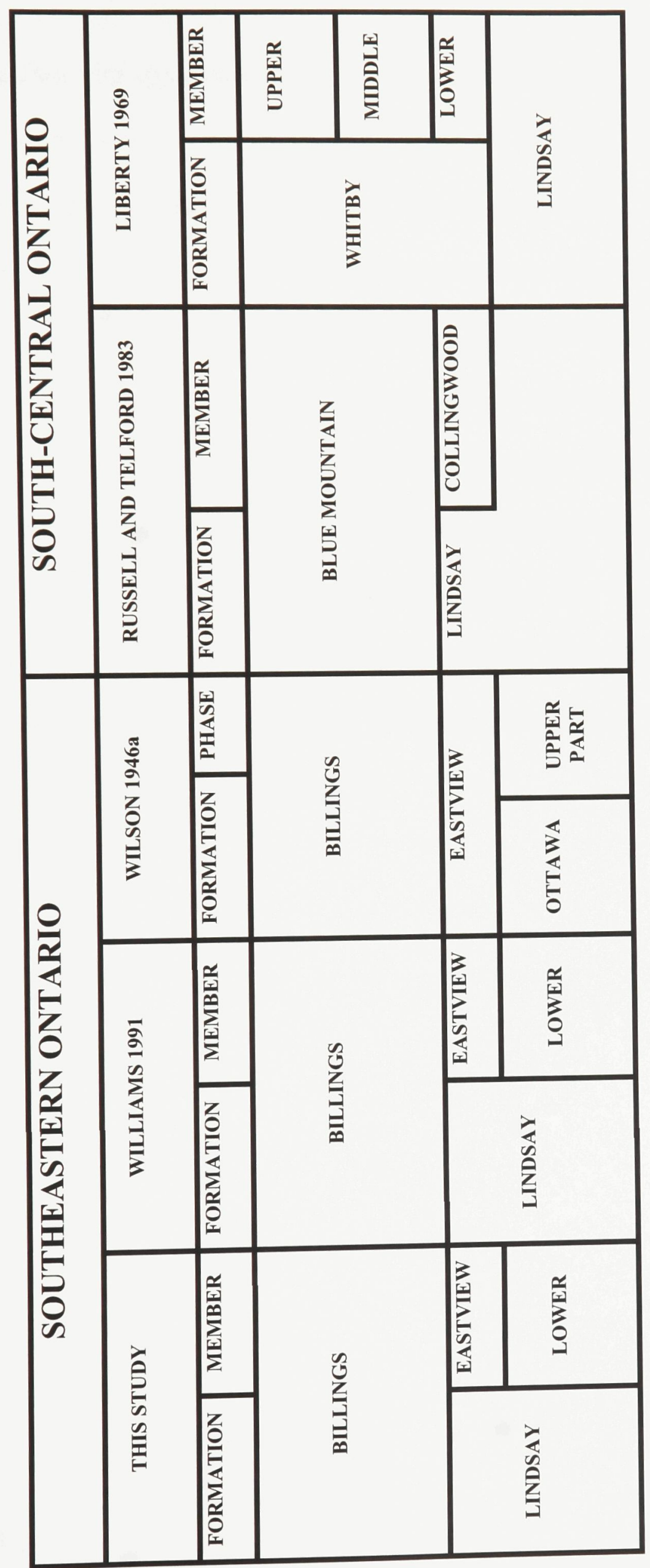


Formation with apparent conformity and consists of very dark grey to black claystone interlaminated by siltstone. In southern Quebec and New York State, the lower member of the Lindsay Formation is correlated with the Tetreauville Formation (Clark 1972a; Clark 1972b) and the Hillier Formation, respectively (Kay 1968; Fisher 1977). The prominent shale-limestone interbeds of the upper (Eastview) Member of the Lindsay Formation have no correlative in southern Quebec and New York State. Considerable paleontological work has been carried out over the last century on strata now hosted by the Lindsay Formation in eastern Ontario. Brachiopods, bryozoans, gastropods, trilobites and crinoids are present and locally abundant (Raymond 1921; Foerste 1924; Fritz 1957; Wilson 1946b-c). Biostratigraphy based on conodonts was imported into the local area from adjacent regions (Barnes et al. 1981), and macrofauna were used to establish biostratigraphic zones (Wilson 1946). 


\section{METHODOLOGY}

This study involved mapping rock sections exposed in quarries, outcrop exposures and in cores (see Figures. 1-3). Stratigraphic sections were measured and described according to bedding, colour, grain size and types, texture, composition, sedimentary structures and bedding contacts. Four cores were examined: (1) GSC \#2 Russell; (2) GSC Billings Bridge, and (3) two cores from the St. Mary's Cement Quarry in Bowmanville, ON. These last two cores were examined in order to establish a lithostratigraphic comparison from outside of the Ottawa Embayment. The first two cores are housed at the Tunney's Pasture facility of the Geological Survey of Canada, whereas those from Bowmanville were donated to the Department of Earth Sciences, Carleton University.

Shale and limestone samples were taken from the field (outcrop and quarry exposures) and from cores for geochemical, mineralogical and petrographic analysis. Thin sections were made from samples representative of the variety of lithofacies. The thin sections were prepared and stained with Alizarin Red-S and potassium ferrocyanide solutions to help distinguish between calcite and dolomite, and their relative iron content (Dickson 1966). Thin sections were examined using a standard petrographic microscope.

Dunham's (1962) classification of carbonate rocks was used for petrographic and field descriptions. In addition, thin sections were examined using cathodoluminescence microscopy to help differentiate stages of carbonate paragenesis. A Nuclide Luminoscope ELM model 2B was operated at a voltage of $9-12 \mathrm{kV}$, at $0.4-0.5$ milliamps beam current at less than 25 millitorr. 
Shale samples from selected stratigraphic locations were taken to identify mineralogy using the X-ray diffraction (XRD). Samples were powdered and added to a solution of water and trace amounts of sodium chloride, the latter acting as an internal mineral ID standard to correct for any machine offset. The solution was poured on a glass slide and left to dry. A Phillips PW 1710 automated diffractometer (Carleton University) with operating conditions set at $35 \mathrm{kV}$ and $50 \mathrm{Ma}$ was used. Scans were made over the 3 to 65 $2 \theta$ degree scan range at a scanning speed of 0.02 degrees per second with an interval time of 50 seconds.

A polished thin section was prepared for electron microprobe analysis (Carleton University) to evaluate overgrowth calcite cement, crinoid ossicles, ferroan calcite cement and dolomite. The following elements were analyzed; $\mathrm{Ca}, \mathrm{Mg}, \mathrm{Fe}, \mathrm{Mn}, \mathrm{Sr}, \mathrm{Na}, \mathrm{Ba}$ and Si by electron microprobe. A Camebax MBX automated electron microprobe with four wavelength-dispersive spectrometers and an Energy-Dispersive X-ray (EDX) spectrometer was used. Absorbed current was 15 nannoamps, measured in a Faraday cup.

Stable isotope analyses of oxygen and carbon were conducted at the G.G Hatch Isotope Laboratory at the University of Ottawa. Samples were collected by microdrilling of the micritic facies, calcite cement and dolomite. The samples were mixed with $0.1 \mathrm{ml}$ of $\mathrm{H}_{3} \mathrm{PO}_{4}$, capped and helium-flushed while the exetainers were horizontal. Measurements were taken at $25^{\circ} \mathrm{C}$ for 24 hours (calcite) or $50^{\circ} \mathrm{C}$ (dolomite) and was followed by extraction in continuous flow. Measurements were taken on a Delta XP and a Gas Bench II, from Thermo Finnigan, with $2 \sigma$ permil, then normalized using international standards NBS-18, NBS-19, AND LSVEC. 


\section{STRATIGRAPHY OF THE LINDSAY FORMATION}

\section{Thickness}

There is no outcrop of the entire Lindsay Formation, but cores provide the complete section of this formation. Table 1 shows the thicknesses of sections found in outcrops, quarry exposures, and cores in eastern Ontario. They are compared with the section from the St. Mary's Quarry (Bowmanville).

In the City of Ottawa area, the lower member (herein referred to as the Nepean Point Member; Appendix I) of the Lindsay Formation is about $\sim 28 \mathrm{~m}$ thick according to core sections. In eastern Ontario, the Nepean Point Member in the Russell core (Location $\mathrm{G}$ ) is $\sim 31 \mathrm{~m}$ thick according to core sections. It remains unknown if the lower member has a constant thickness across eastern Ontario or may thicken to the east, toward Quebec. In Quebec, the unit equivalent to the Lindsay Formation is 125 m thick (Williams 1991).

There are only two complete core sections of the upper (Eastview) member of the Lindsay Formation (Table 1). From this, the unit appears to thicken to the northwest, from $\sim 7 \mathrm{~m}$ in the Russell core to $\sim 11 \mathrm{~m}$ in the Billings Bridge core.

In comparison, the lower member of the Lindsay Formation in the outcrop belt in central Ontario has a thickness of $\sim 55-60 \mathrm{~m}$ (Liberty 1969). He suggested that the unit would thicken 
Page Facing 16

Table 1. Approximate stratigraphic thicknesses of the Lindsay Formation (where * means incomplete section). Names of quarries are taken from Derry et al. 1989. 


\begin{tabular}{|c|c|c|c|c|c|c|c|c|c|c|c|c|}
\hline 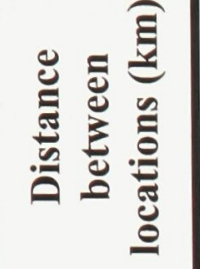 & & $\begin{array}{l}\bar{\sigma} \\
\bar{b} \\
\ddot{\theta} \\
\dot{\alpha}\end{array}$ & $\begin{array}{l}\dot{J} \\
\dot{i} \\
\ddot{U} \\
\dot{\omega}\end{array}$ & 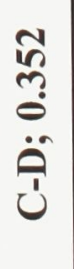 & 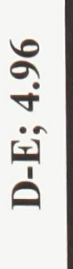 & \begin{tabular}{l}
$\hat{\infty}$ \\
0 \\
$\ddot{0}$ \\
$\ddot{1}$ \\
\multicolumn{1}{c}{}
\end{tabular} & 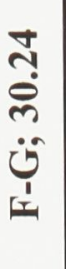 & $\frac{n}{\ddot{1}}$ & 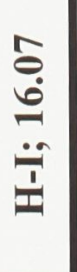 & $\begin{array}{l}\stackrel{\text { iे }}{\dot{m}} \\
\ddot{m} \\
\ddot{i}\end{array}$ & 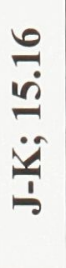 & 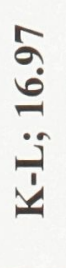 \\
\hline 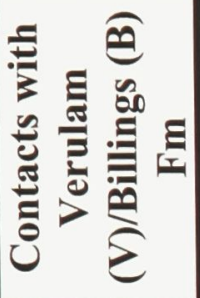 & & & $\varepsilon$ & $\varepsilon$ & $\begin{array}{l}\infty \\
2 \\
2\end{array}$ & & $\begin{array}{l}0 \\
2 \\
2\end{array}$ & $\sum$ & $\varepsilon$ & $\varepsilon$ & & \\
\hline 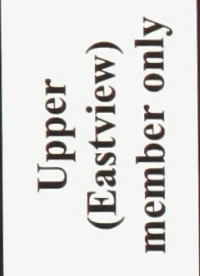 & & & & & $=$ & $\begin{array}{l}\text { 苂 } \\
\stackrel{\theta}{0}\end{array}$ & $r$ & & & & & \\
\hline 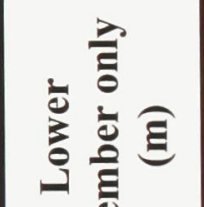 & 苑 & 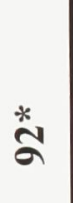 & $\begin{array}{l}* \\
\stackrel{*}{*} \\
\end{array}$ & $\frac{*}{\stackrel{*}{*}}$ & $\stackrel{n}{\sim}$ & $\underset{\text { ले }}{*}$ & $\bar{m}$ & 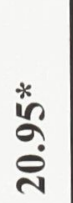 & $\stackrel{*}{N}$ & 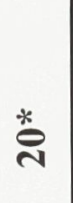 & 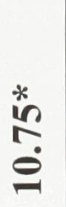 & in \\
\hline 冚 & อั & : & $\frac{0}{0}$ & 을 & 巳ั & $\frac{\text { อ̊ }}{\stackrel{0}{0}}$ & : & $\frac{\stackrel{0}{0}}{\stackrel{0}{0}}$ & $\begin{array}{l}\frac{2}{0} \\
\frac{0}{0} \\
0\end{array}$ & है & 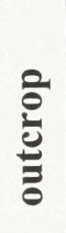 & 를 \\
\hline $\begin{array}{l}\stackrel{\text { E }}{\text { Z }} \\
\text { Z }\end{array}$ & ف를 & 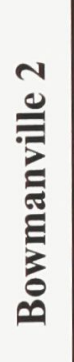 & 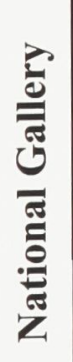 & 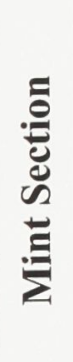 & 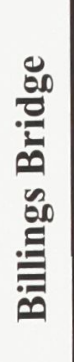 & 苞 & 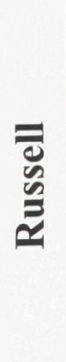 & 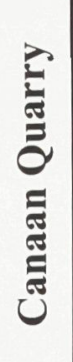 & 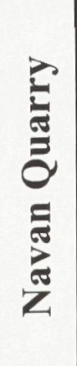 & 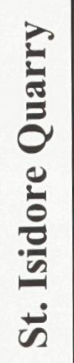 & 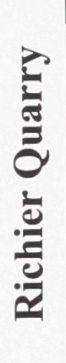 & 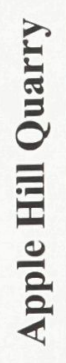 \\
\hline 巳 & $<$ & $\varphi$ & 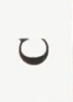 & a & [1工 & 工工 & ט & \pm & - & $r$ & 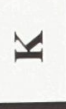 & \\
\hline
\end{tabular}


into more southerly parts of the Ontario. In the Bowmanville region, for example, the core from the St. Mary's Quarry reveals a thickness of $\sim 95 \mathrm{~m}$ (Table 1), nearly three times that of the thickness in the City of Ottawa (Table 1). In contrast, the Collingwood Member of the Lindsay Formation in central Ontario and along the margin of the Michigan Basin which underlies southwestern Ontario is $\sim 10 \mathrm{~m}$ thick. This is of the same magnitude as noted in eastern Ontario.

\section{Lithofacies}

Sediment grain size within the Lindsay Formation ranges from fine- to coarse- sand and gravel throughout the lower member whereas sedimentary rocks of the Eastview Member are typically mud dominated. Descriptions and interpretations of lithofacies are based on observations made in the field, and from both thin sections and rock slabs in the laboratory. Lithofacies are defined on the basis of grain types, color, bedding style, nature and type of sedimentary structures, bounding surfaces, fossil content, diagenetic features and facies associations. The carbonate ramp model used in this study is by Burchette and Wright 1992. Eight lithofacies have been recognized in the Lindsay Formation (Table 2). Lithofacies are divided into carbonate-dominated (C1-C5; mid-ramp depositional setting) and siliciclastic-dominated (S1-S3; offshore, outer-ramp setting) groups. 
Page Facing 18

Table 2. Attributes of carbonate (C-) and siliciclastic (S-) lithofacies of the Lindsay Formation (where SWB means storm wave base and FWWB means fair weather wave base). 


\begin{tabular}{|c|c|c|c|c|c|}
\hline 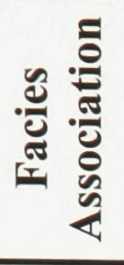 & 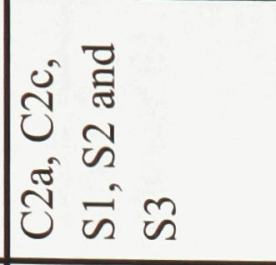 & & 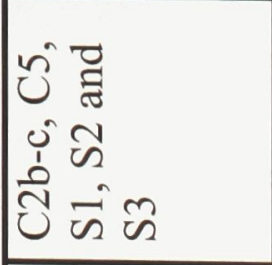 & 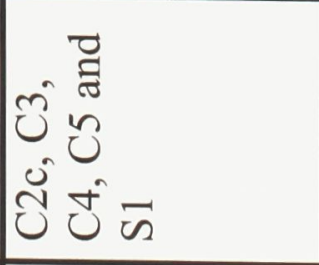 & 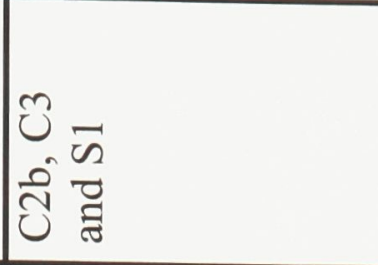 \\
\hline 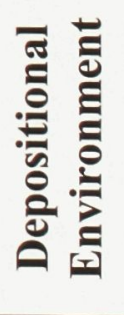 & 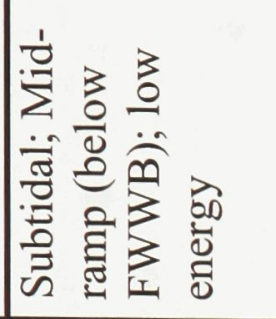 & & 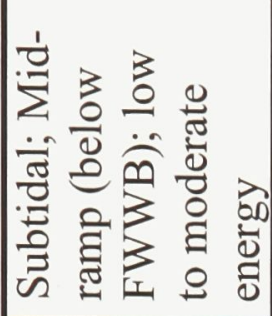 & 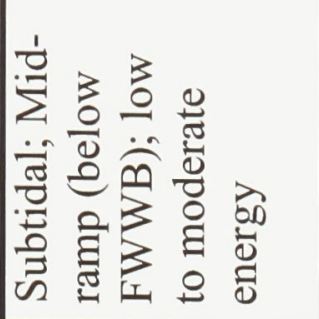 & 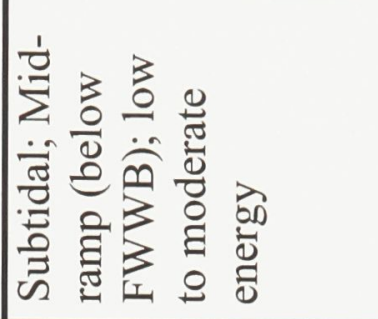 \\
\hline 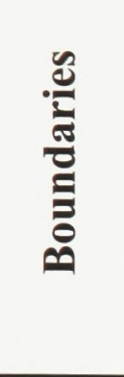 & 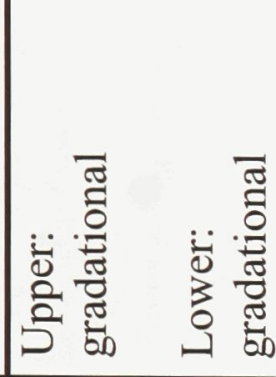 & & 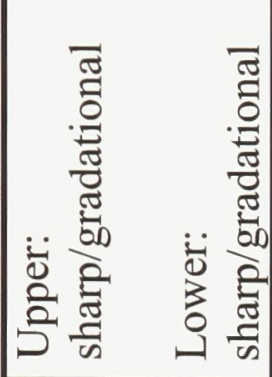 & 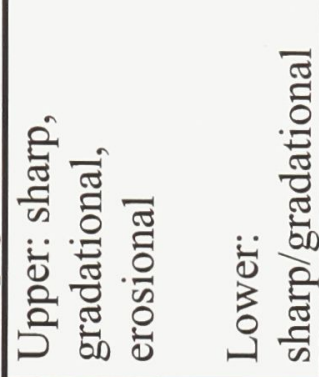 & 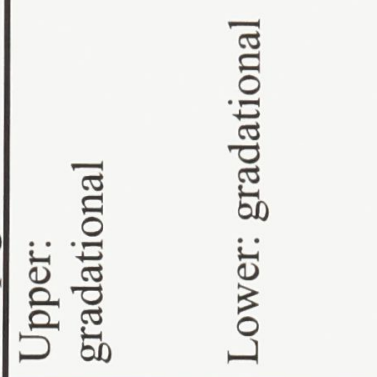 \\
\hline 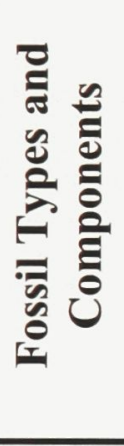 & 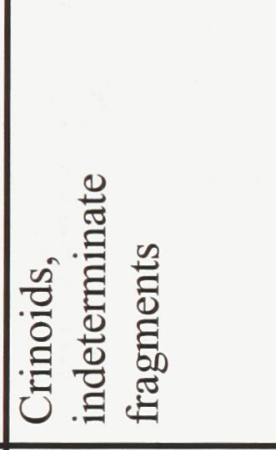 & & 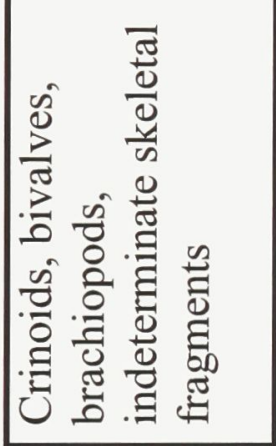 & 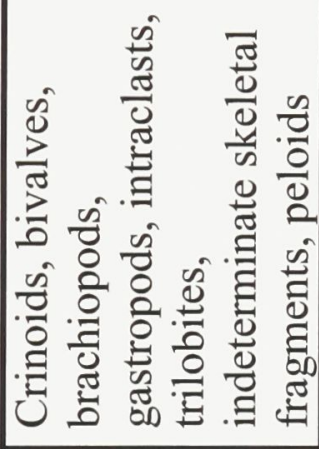 & 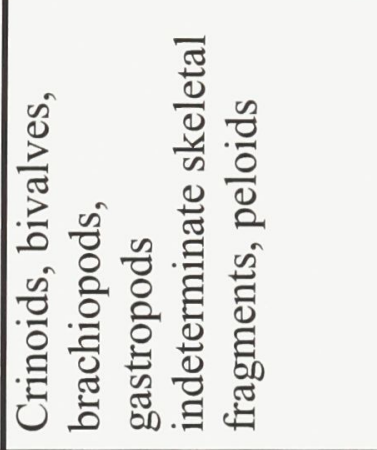 \\
\hline 递 & 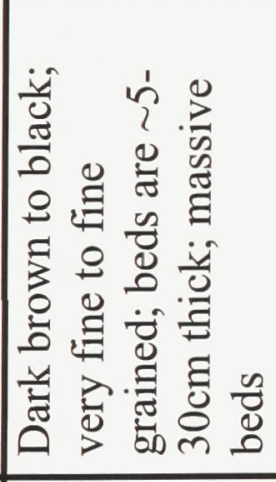 & 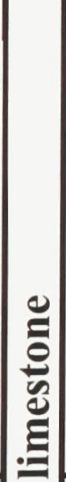 & 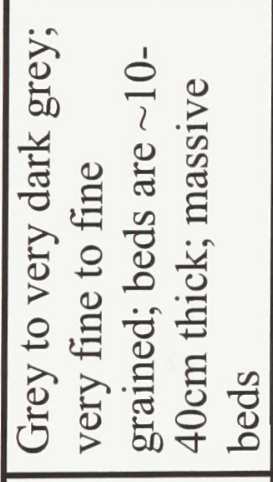 & 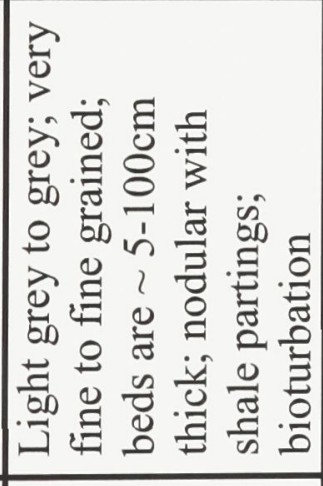 & 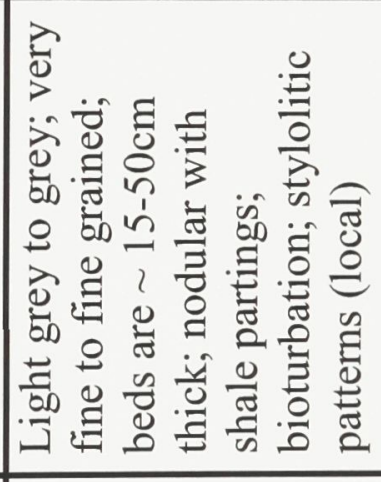 \\
\hline 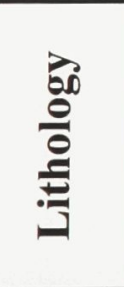 & 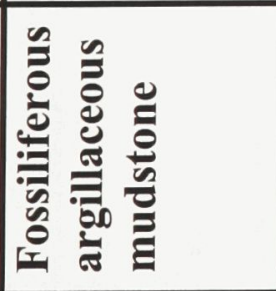 & | & 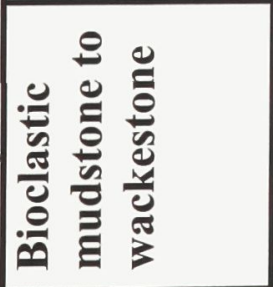 & 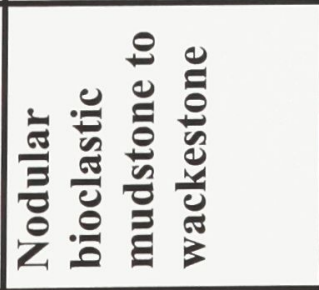 & 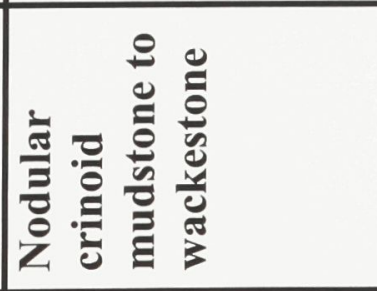 \\
\hline 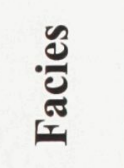 & U & $\mathcal{U}$ & త్ & ปิ & 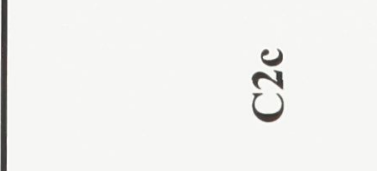 \\
\hline
\end{tabular}




\begin{tabular}{|c|c|c|c|c|}
\hline 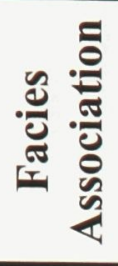 & & 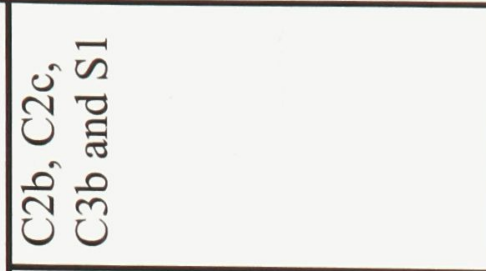 & 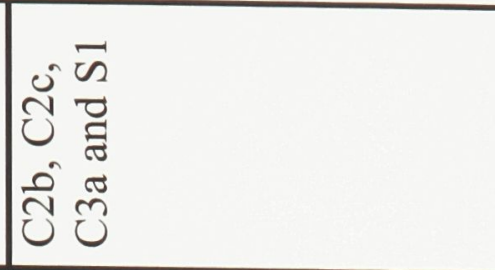 & ปే \\
\hline 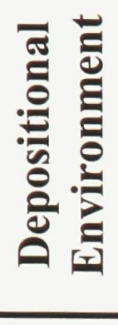 & & 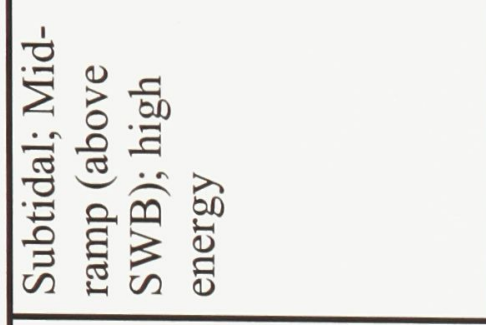 & 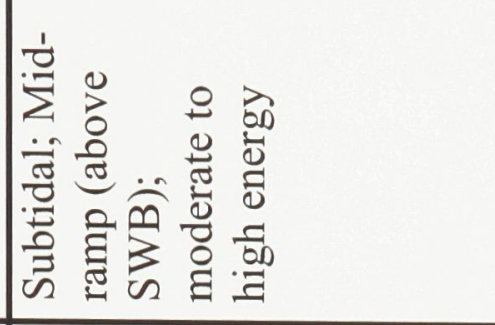 & 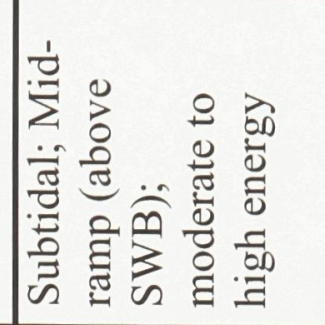 \\
\hline 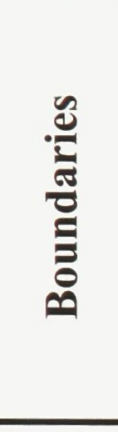 & & 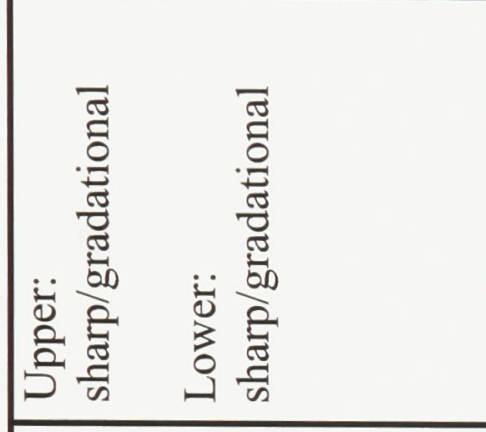 & 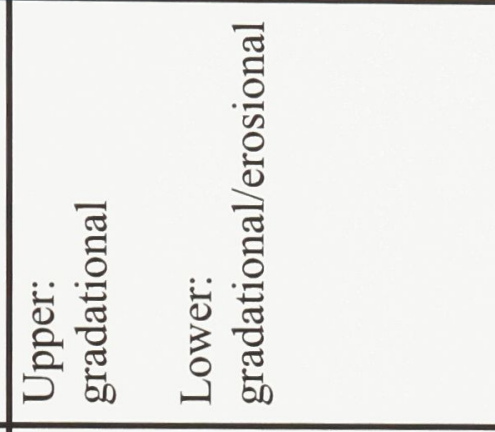 & 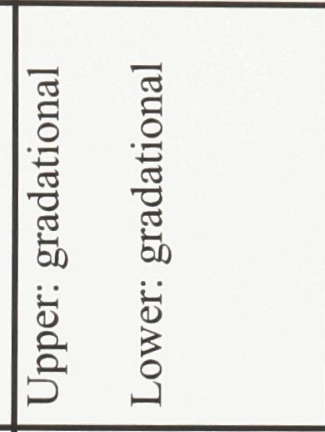 \\
\hline 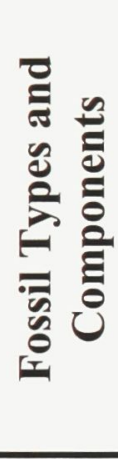 & & 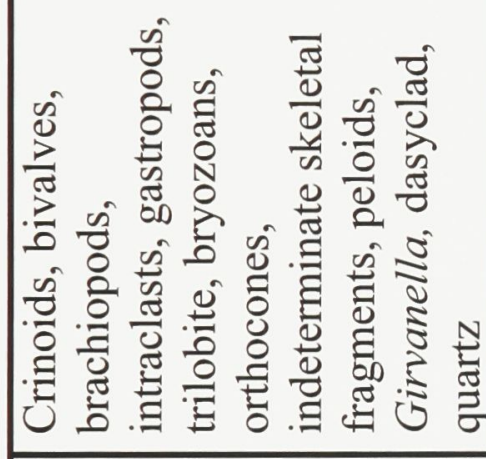 & 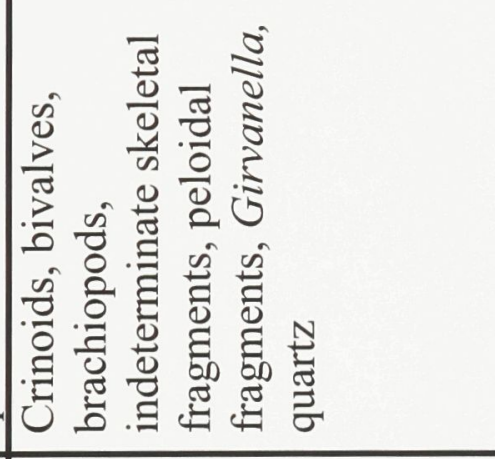 & 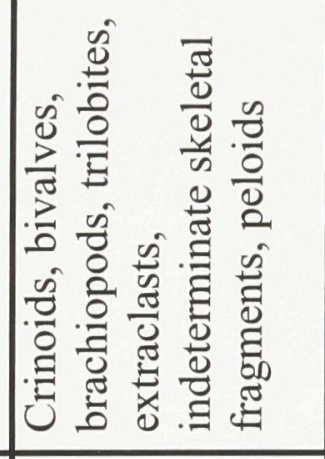 \\
\hline 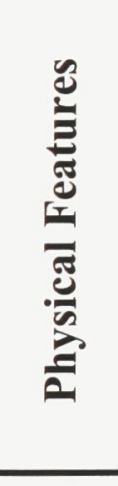 & & 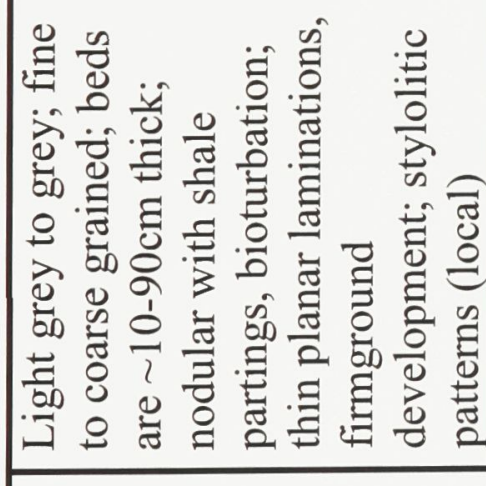 & 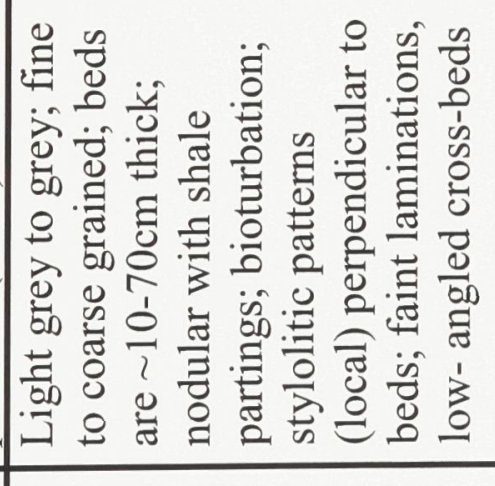 & 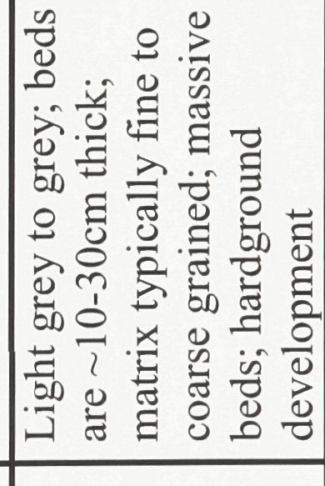 \\
\hline & 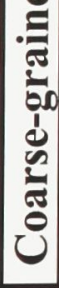 & 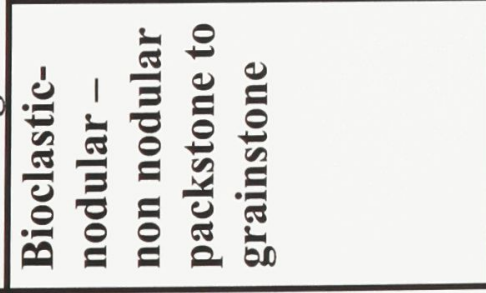 & 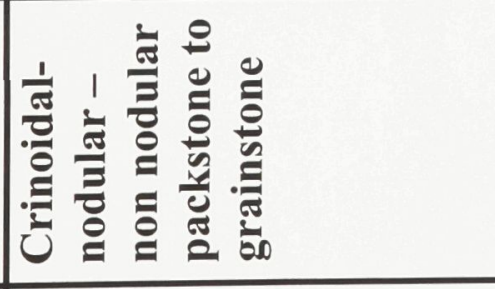 & 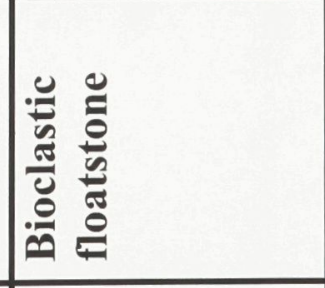 \\
\hline 苞 & 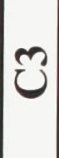 & $\tilde{U}$ & లి & U \\
\hline
\end{tabular}




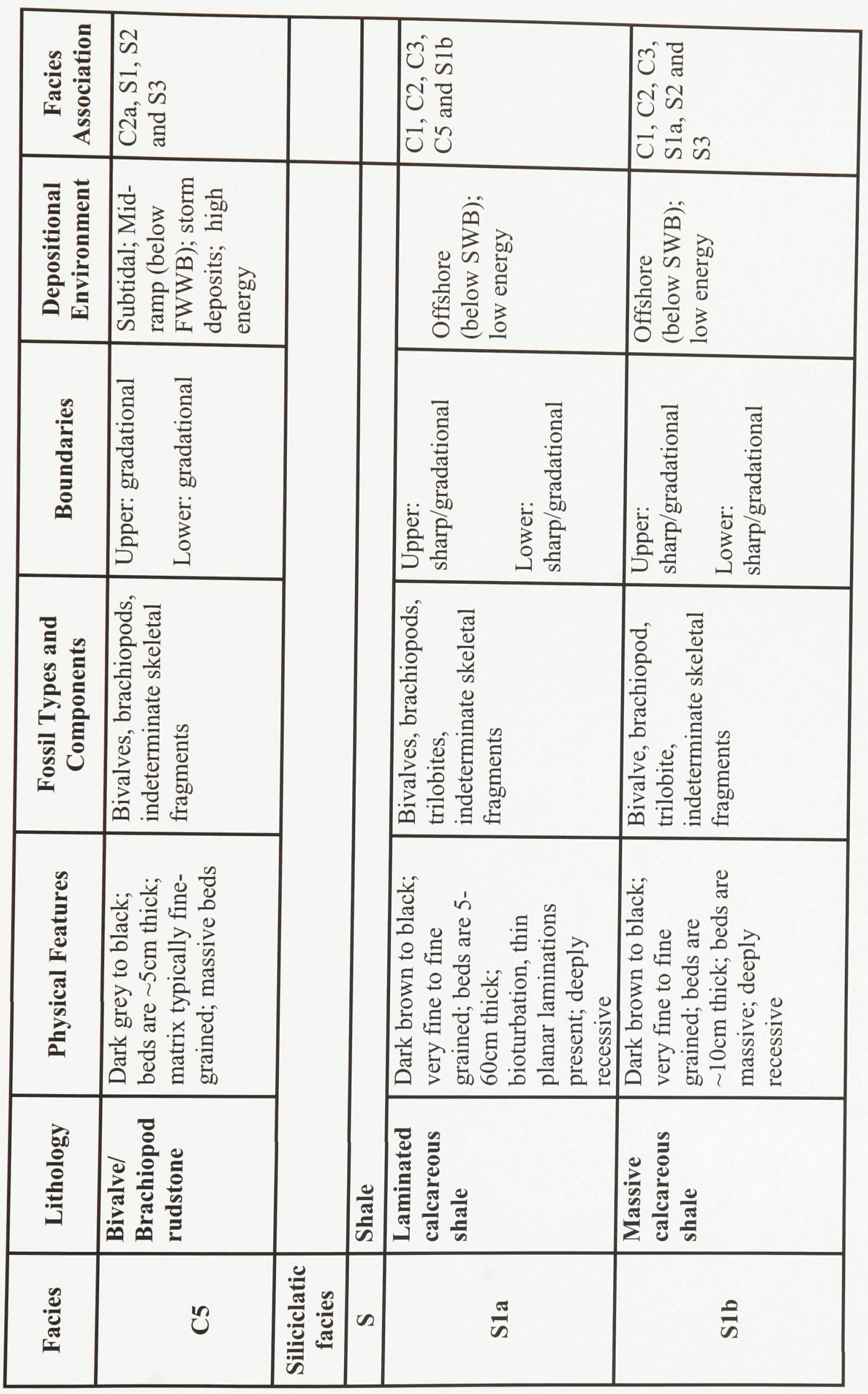




\begin{tabular}{|c|c|c|}
\hline 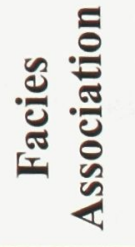 & 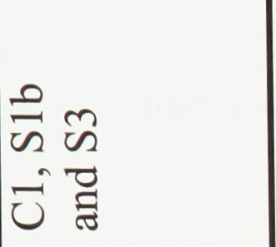 & 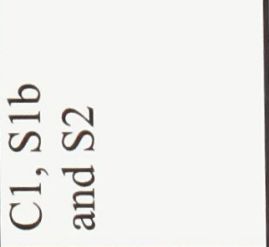 \\
\hline 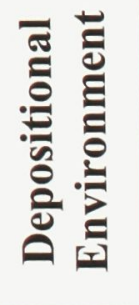 & 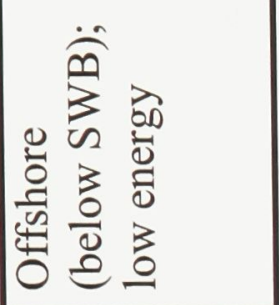 & 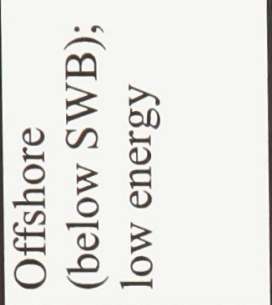 \\
\hline 总 & 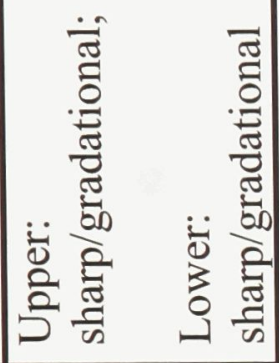 & 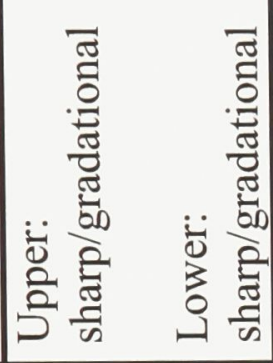 \\
\hline 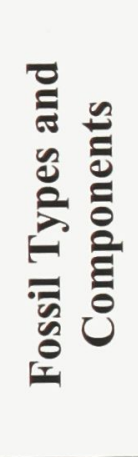 & 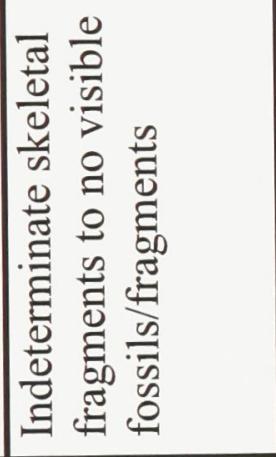 & 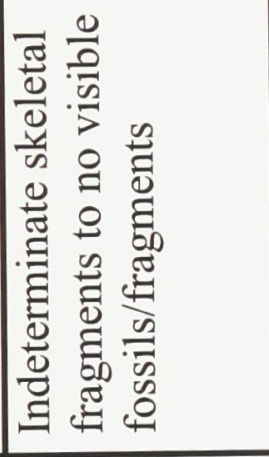 \\
\hline 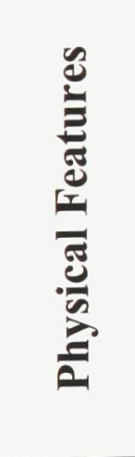 & 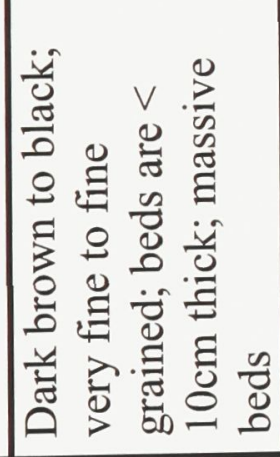 & 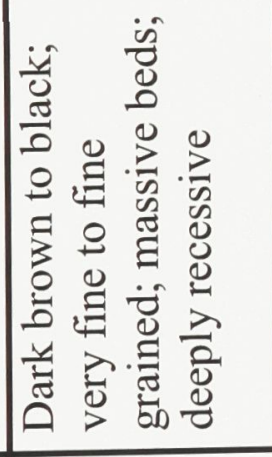 \\
\hline 苞 & 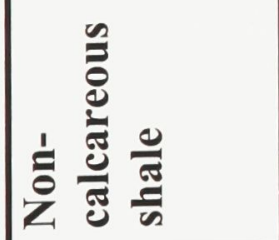 & 巻 \\
\hline 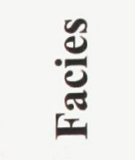 & ֶै & $\tilde{\omega}$ \\
\hline
\end{tabular}




\section{Carbonate Lithofacies}

\section{C1: Fossiliferous argillaceous mudstone}

This lithofacies consists of very fine to fine grained, dark brown to black beds of fossiliferous argillaceous mudstone (Figure 7A). The upper and basal contacts with other lithofacies are gradational. The major grain types are crinoid ossicles along with indeterminate (very fine-grained) skeletal fragments. Carbonate grains are usually broken, the beds lack obvious evidence of bioturbation. This lithofacies is generally present in the uppermost Nepean Point Member through to the Eastview Member. The general lithology and crinoid-dominated fauna identifies a marine, subtidal, mid-ramp and low energy environment.

\section{C2: Fine-grained limestone}

\section{C2a: Bioclastic mudstone to wackestone}

This lithofacies is represented by very fine to fine grained beds of limestone (Figures 7B \& C). They are typically grey on a fresh surface, and weather to brownish grey. Bed thickness ranges from 10 to $40 \mathrm{~cm}$ and the upper and lower boundaries of the beds are sharp and gradational (Figures 7D \& E). Overall, the relatively abundant fossils remain whole, with only local fragmentation, and they include crinoids, bivalves, brachiopods and indeterminate skeletal fragments. Beds are massive and typically lack evidence of bioturbation. This lithofacies is generally present in the Eastview Member (Figure 7D) but occurs locally within the Nepean Point Member (e.g., Location G; Russell core). 
Figure 7. Characteristics of $\mathrm{C} 1$ and $\mathrm{C} 2$ Lithofacies

A. Fossiliferous argillaceous mudstone (Lithofacies C1). Arrow showing the crinoids. Locality E.

B. Fine grained limestone (Lithofacies C2). Locality A.

C. Very fine grained lime mudstone (Lithofacies C2); Locality F.

D. Bioclastic mudstone to wackestone (C2a) interbedded with laminated calcareous shale (S1a). Note the relative thickness of the calcareous shale beds and the fine grained limestone beds; Locality F.

E. Bioclastic limestone ( $\mathrm{C} 2$ and $\mathrm{C} 3)$ interbedded with argillaceous mudstone (C1). Arrows showing the nodular fabric of the Nepean Point Member. Locality E.

F. Bioclastic, nodular fine grained limestone. Arrow at the top of the photograph illustrating faint shale partings and the arrow at the bottom showing the nodular fabric (Lithofacies C2b); Locality G. 

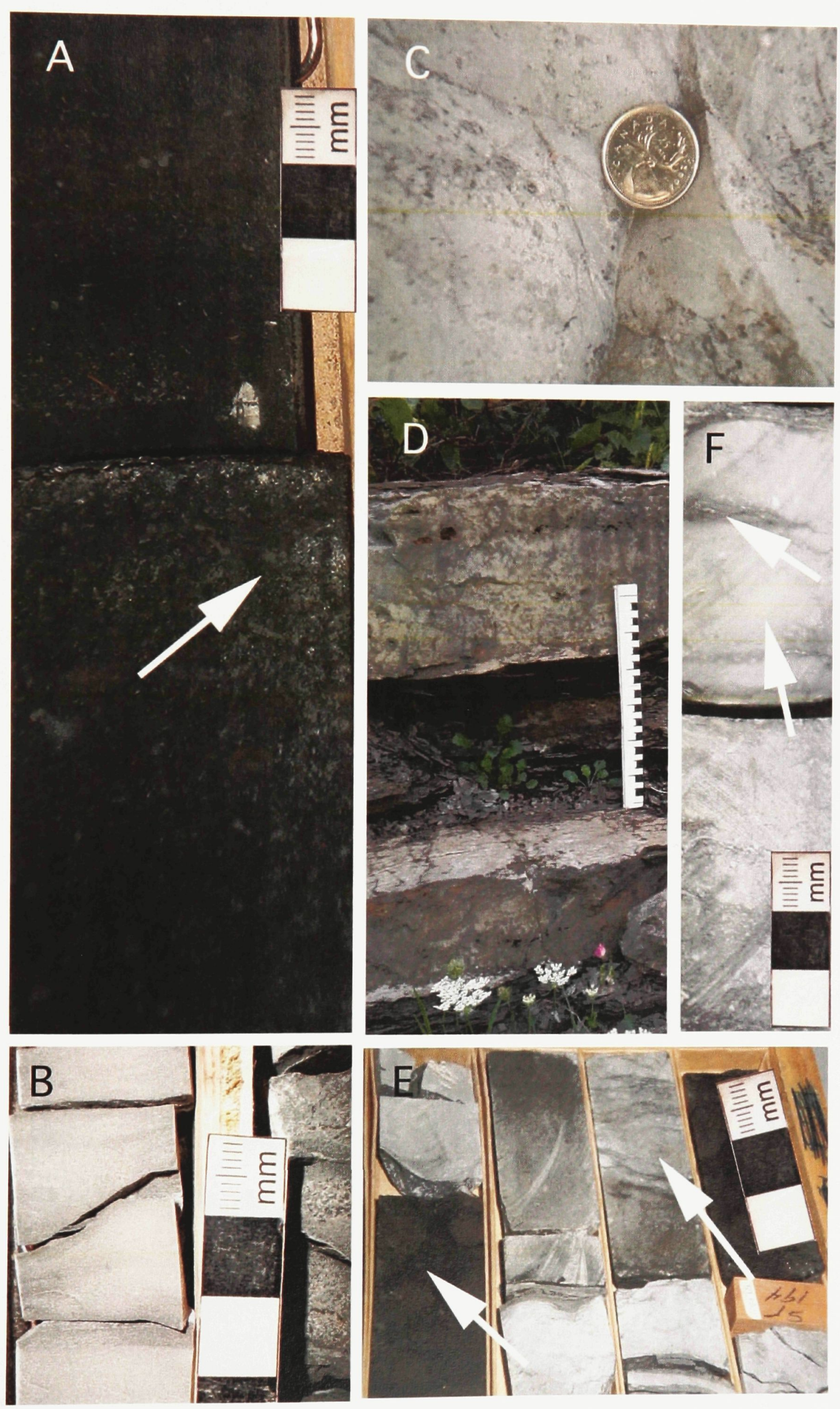
The faunal diversity, abundance, presence of crinoids, and environmental stability suggests deposition in normal marine, subtidal, mid-ramp and low to moderate energy setting.

\section{C2b: Nodular bioclastic mudstone to wackestone}

This lithofacies is very similar to lithofacies $\mathrm{C} 2 \mathrm{a}$ in that it also contains a diverse faunal assemblage of crinoids, bivalves, brachiopods, gastropods and trilobites. However, it contains prominent (20\%) occurrence of intraclasts and peloids, and exhibits a very prominent nodular fabric defined by shale partings (Figure 7F). The beds are light grey to grey and are very fine to fine grained (Figure 8A). Average thickness of beds is between 5 and $100 \mathrm{~cm}$, and bedding contacts are generally sharp and gradational. Well defined vertical burrows (Skolithos sp.) are also present, and extend downwards from bedding planes (Figure 8B). In some cases, extensive bioturbation erases any pre-existing sedimentary structures (e.g., laminations) based on lateral gradient in the extent of bioturbation. This lithofacies is rarely developed in the Nepean Point Member. The finegrained fabric and a high faunal diversity, including crinoids, are indicative of a normal marine, subtidal, mid-ramp and low to moderate energy environment.

\section{C2c: Nodular crinoidal mudstone to wackestone}

This lithofacies is similar to $\mathrm{C} 2 \mathrm{~b}$. The beds are generally light grey to grey and weather to brownish grey. They are very fine to fine grained. Beds are typically 15 to $50 \mathrm{~cm}$ thick and are fossiliferous, dominated by crinoidal fragments (Figure 8C). Bivalves, 
Figure 8. Characteristics of $\mathrm{C} 2$ and $\mathrm{C} 3$ Lithofacies.

A. Photomicrograph (plane light) of very fine grained mudstone to wackestone (Lithofacies C2a). Locality F. x30.

B. Thin to thick beds of extensively bioturbated fine to coarse grained limestone beds. Note that the limestone beds are also nodular but the extensive bioturbation has destroyed the bedding. Arrows illustrating the vertical burrows (skolithos sp.). Locality D.

C. Crinoidal-rich limestone. Abundance of crinoidal fragments in the center of the photograph (Note the direction of the arrow). Lithofacies C3b. Locality G.

D. Large nodular fine grained limestone with thin shale laminae wrapping around the large nodules. Arrows pointing in the direction of the limestone nodules (lower arrow) and undulating shale partings (arrow next to the coin). The well developed nodules are found in the lower portion of the Eastview member at Location F.

E. Photomicrograph (plane light) of sub-horizontal stylolite. Note the dolomite and quartz grains within and around the stylolite. Photograph also illustrating the peloidal fabric of the Nepean Point Member. Locality K. x12.5. 

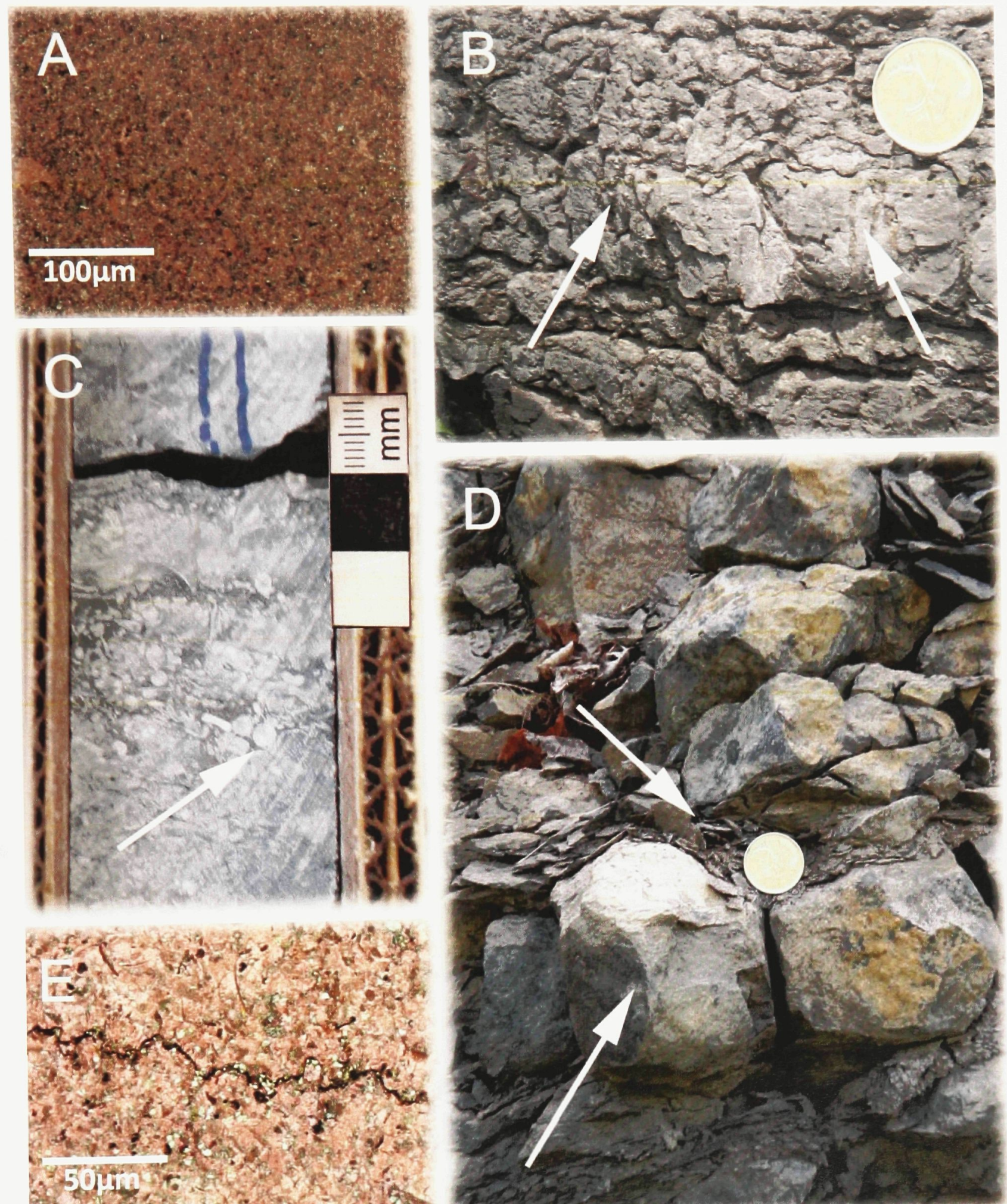

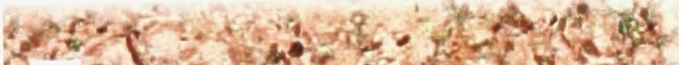

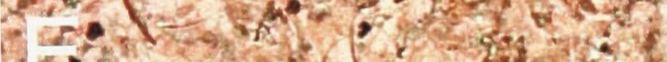

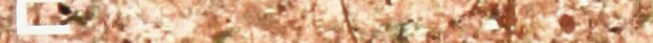

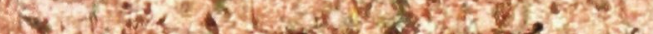

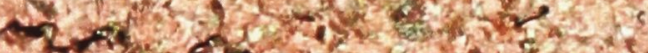

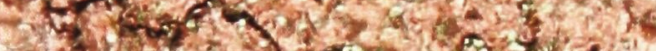

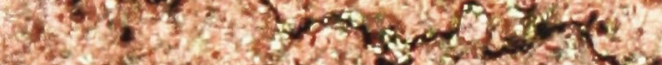

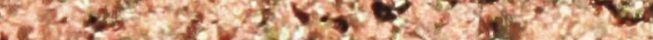

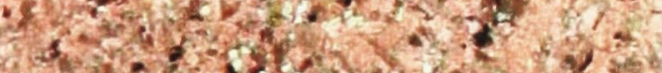

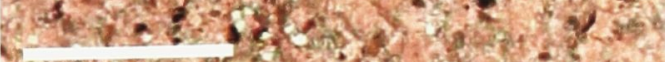

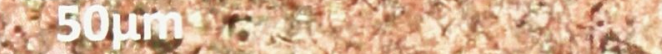

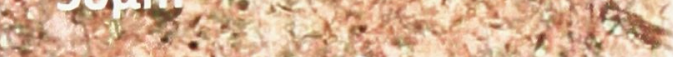

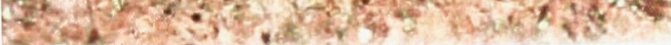


brachiopods and gastropods are represented, but low in abundance. Crinoid ossicles are usually intact but the other minor fossils are commonly disarticulated and broken. Peloids and indeterminate skeletal fragments are also present. Both upper and lower bedding contacts are gradational. Beds are typically bioturbated, with vertical to sub-vertical burrows prevalent. Abundant, thin discontinuous undulating shale partings create the characteristic nodular appearance (Figure 8D). Local vertical to sub-horizontal stylolitic patterns are present (Figure 8E). This lithofacies is rare in the Nepean Point Member. This lithofacies is interpreted to document a normal marine, subtidal, mid-ramp of low to moderate energy setting.

\section{C3: Coarse-grained limestone}

\section{C3a: Bioclastic nodular to non-nodular packstone to grainstone}

Bedding in this lithofacies appears to form metre-thick stacked units. A good example can be seen in outcrop below the National Art Gallery (Locality C) in Ottawa. Closer inspection shows that bioturbation has overprinted a finer-scale $(<10 \mathrm{~cm}$ lamination) stratigraphic fabric.

The beds in this lithofacies are light grey to grey on a fresh surface, but weather to a pale grey or brownish grey. Grains are generally fine to coarse grained with limestone beds varying from 10 to $90 \mathrm{~cm}$ in thickness and the bedding contacts are usually gradational or sharp. There is a diverse faunal assemblage that includes crinoids, bivalves, brachiopods, gastropods, bryozoans, trilobites and orthocones that makes up about $70 \%$ of the total grains present (Figure 9A). The skeletal material is usually broken. Other subordinate 
Figure 9. Characteristics of C3a Lithofacies.

A. Photomicrograph (plane light) of coarse-grained bioclastic limestone. Note the abundance of skeletal grains and the large bryozoan at the center of the photograph (arrow). Pore spaces completely filled with coarse blocky cement. Lithofacies C3. Locality L. x12.5.

B. Microbial overgrowths on skeletal fragment along with Girvanella and peloids (Lithofacies C3a). Arrows on the left is showing the microbial overgrowth and the arrow on the right is showing Girvanella (Filamentous tubes with thick micritic walls). Found within the coarse-grained facies. Locality L. x35.

C. Arrow showing Girvanella. Microbial fragments and peloids also present. Found within the coarse-grained lithofacies (C3). Locality K. x35. (Lithofacies C3a, b). Locality L. x35.

D. Microbial overgrowth breaking down to form circular peloids. Arrows showing the microbial overgrowths (arrow on the left) and the peloids (arrow on the right). (Lithofacies C3a, b). Locality L. x35.

E. Microbial encrustations on skeletal fragments (arrows). Note the peloids within the coarse-grained lithofacies (C3). Locality J. x20.

F. Microbial overgrowth on skeletal fragment (arrow) with tiny cavities containing crystalline dolomite (Lithofacies C2a, b; C3a). Locality I. x35.

G. Green calcareous algae of the order Dasycladacean (Lithofacies C3a). Found within the coarse grained limestone. Arrow showing the dasycladacean algae. Locality F. x16.

H. Photomicrograph (plane light) of sub-horizontal stylolite (arrow at the top) and fracture filled with ferroan calcite (arrow). Note that the stylolite and fracture are perpendicular to the low-angled cross beds. Locality I. x16. 

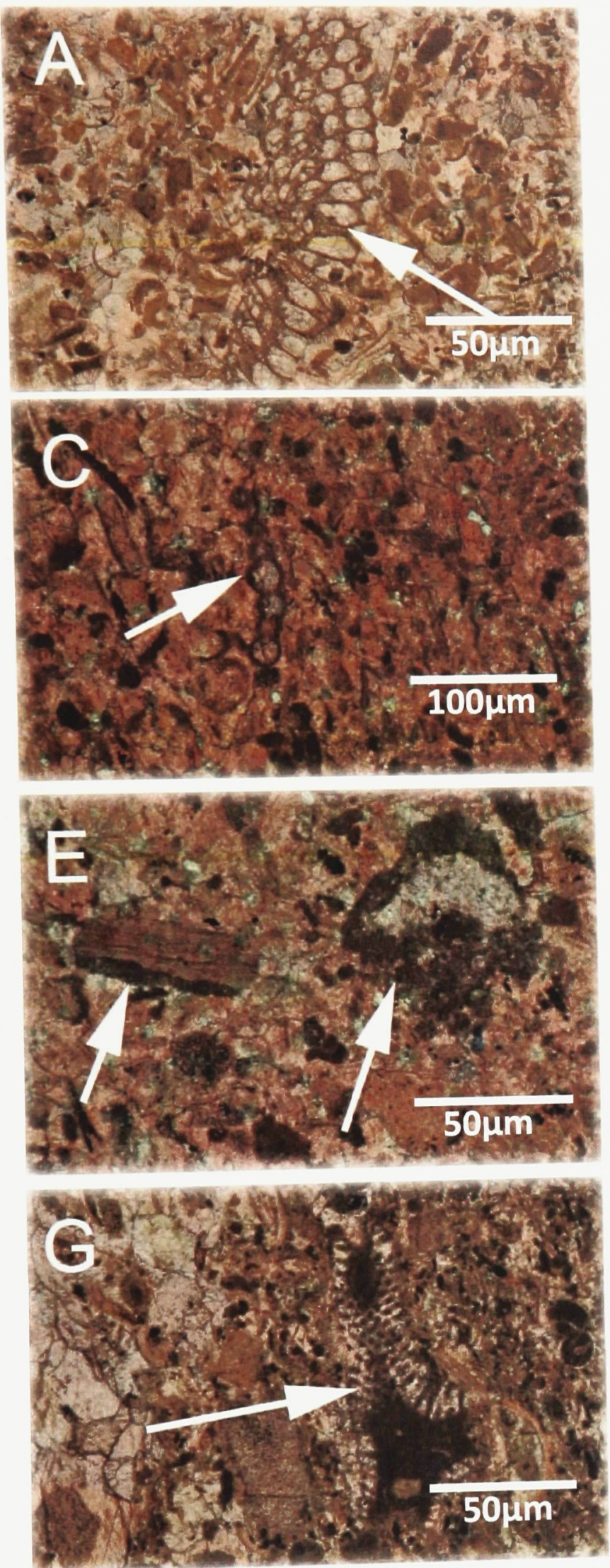
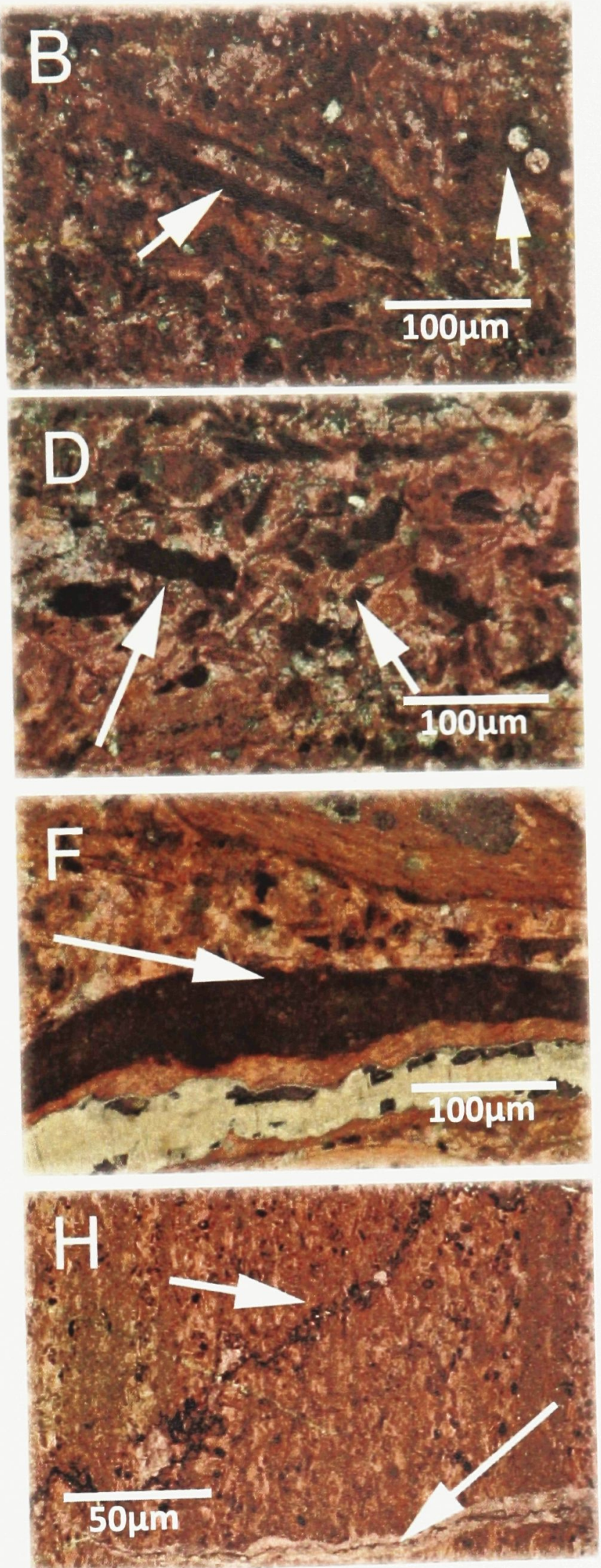
components include intraclasts, peloids and indeterminate skeletal fragments. The alga Girvanella is present locally as loose filamentous tubes with thick micritic walls, and occurs commonly with peloids (Figures 9B \& C). Skeletal grains contain thin coatings of microbial overgrowths, and the microbial overgrowths are suggested to breakdown to form the peloidal material (Figures 9D-F). Fragments of the dasycladacean are present, but rare, in this lithofacies (Figure 9G). Beds are abundantly bioturbated with very thin laterally and irregular discontinuous laminae of shale throughout.

The shale partings together with the intensely bioturbated fabric gives this lithofacies the characteristic nodular appearance often attributed to the Lindsay Formation (Figure 10A). Differential weathering of the bioturbated fabric gives this lithofacies a generally biomottled appearance (see Figure 8B). Locally observed features include stylolitic patterns (vertical and sub-horizontal), thin planar laminations of skeletal carbonate are preserved in some beds (Figure 10B) and firmground surfaces (Figure 10C). Angular to sub-angular fine to coarse quartz grains are locally present, often restricted to burrow fills and along stylolites. This lithofacies is the most abundant of all carbonate lithofacies comprising the Lindsay Formation, and occurs at various intervals throughout the Nepean Point Member (Figure 10D).

The diverse and abundant fossils which are commonly disarticulated suggest a subtidal, mid-ramp and high energy setting. However, the presence of the dasycladacean algal fragments indicates that at least locally this environment was of low energy, warm 
Figure 10. Characteristics of C3a and b Lithofacies.

A. Nodular bioclastic fine to coarse grained limestone. Arrows showing the nodular fabric. Note the faint shale laminae wrapping around the nodules. Lithofacies 2bc. Locality G.

B. Limestone beds showing laminations. Arrows illustrating interlaminations of finegrained limestone with coarse-grained limestone. Locality $\mathrm{H}$.

C. Firmground surface (arrow). Lithofacies C3. Locality I.

D. Thick beds of fine grained, bioturbated, nodular limestone interbedded with coarse grained bioclastic limestone bed (arrow). Note that the coarse grained bed is not nodular. Locality D.

E. Photograph showing coarse grained, bioclastic grainstone (arrow). Lithofacies C3a. Loc A. 


$\left(>18^{\circ} \mathrm{C}\right)$ and possibly slightly hypersaline (Wray 1977; Beadle 1988). The common distribution of microbial overgrowths on skeletal fragments and the dasycladacean algae support temporary restriction of the environment, and also illustrate lower accumulation rates and exposure of grains on the seafloor (Wray 1977).

\section{C3b: Crinoidal nodular to non-nodular packstone to grainstone}

This subfacies contains beds that are light grey to grey, and fine to coarse-grained (Figure 10E). Their thickness ranges between 10 and $70 \mathrm{~cm}$, and bedding contacts are gradational to erosional. Crinoid ossicles are the grain type represented, but other grain types include fragments of bivalves and brachiopods (Figure 11A). This lithofacies is frequently finely interbedded with calcareous shale (Figure 11B). Other sedimentary components includepeloids, indeterminate skeletal fragments and Girvanella. Angular, fine grained quartz grains are scattered around and locally found in burrows (Figure 11C). The extent of bioturbation is generally moderate to high. Few discrete trace fossils observed belong to the Skolithos sp. This subfacies has a nodular fabric along with undulating shale partings. Local stylolitic patterns perpendicular to bedding planes are present. Other sedimentary features which are locally observed are faint planar laminations and lowangled cross beds (Figure 11D). This lithofacies is present locally at various intervals through the Nepean Point Member.

Extensive fragmentation of bioclasts usually suggests energetic conditions or predation (Brett and Baird 1986), and for the Ordovician the prime benthic predator was the trilobite. Cross-bedding, laminations, vertical burrows, and overall coarse-grained nature 
Figure 11. Characteristics of C3 and C4 Lithofacies.

A. Very coarse grained bioclastic packstone to grainstone. Note the abundance of crinoids (arrow) and skeletal fragments. Lithofacies C3a, b. Locality D.

B. Coarse grained limestone beds interbedded (arrow) with laminated calcareous shale (S1a). Note the thickness of the calcareous shale bed (arrow next to the coin). Locality D.

C. Photomicrograph (plane light) of fine to coarse grained angular to sub-angular quartz grains. Arrow showing a quartz grain. Locality J. x35.

D. Photomicrograph (plane light) showing faint and low-angled cross laminations (SW orientation). Note the siliciclastics embedded within the laminations. Locality $\mathrm{H}$.

E. Photomicrograph (plane light) of bioclastic floatstone with a fine-coarse grained matrix. Note the brachiopods and crinoids. Lithofacies C4. Locality J. x5.8.

F. Photomicrograph (plane light) of lithoclastic floatstone with coarse grained matrix. Arrows illustrating the lithoclasts. Lithofacies C4. Locality H. x20. 

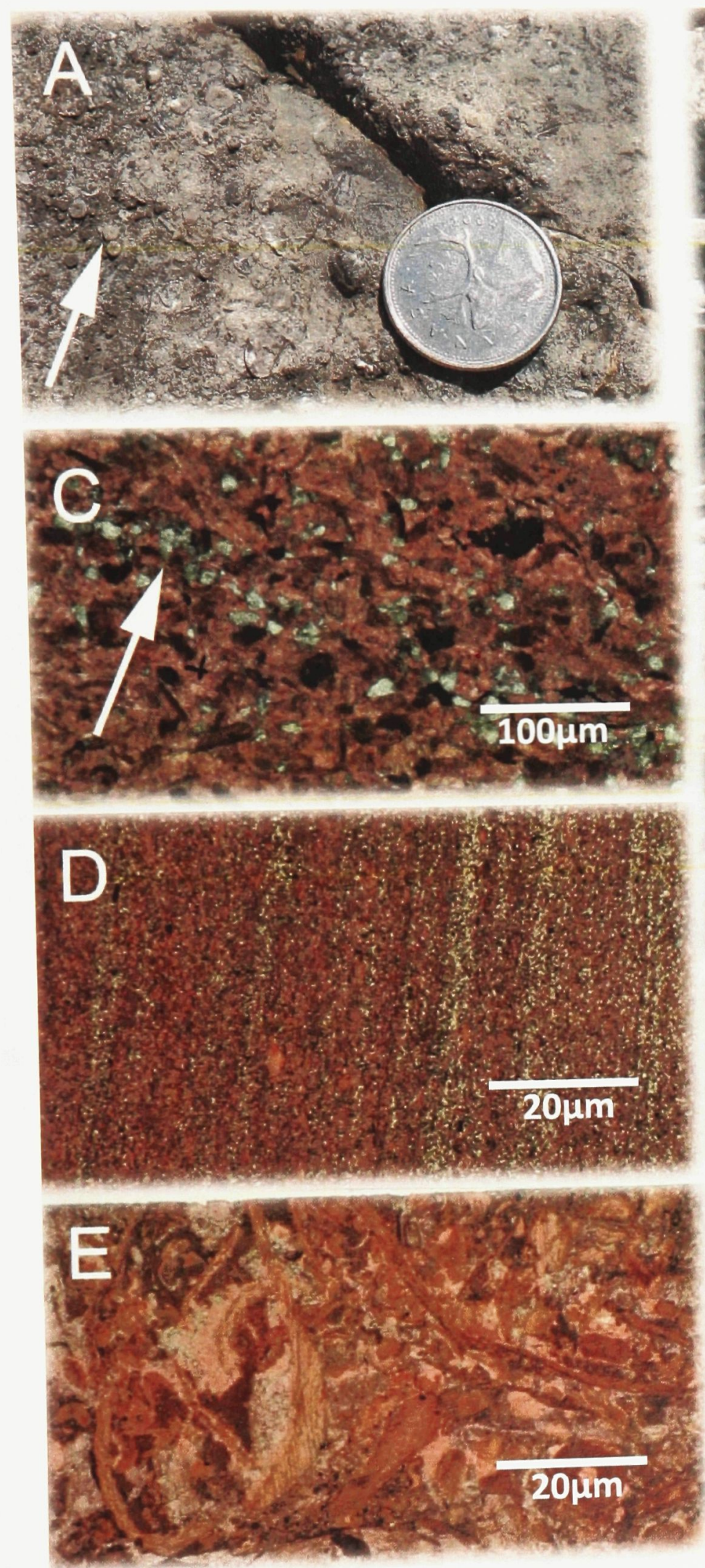
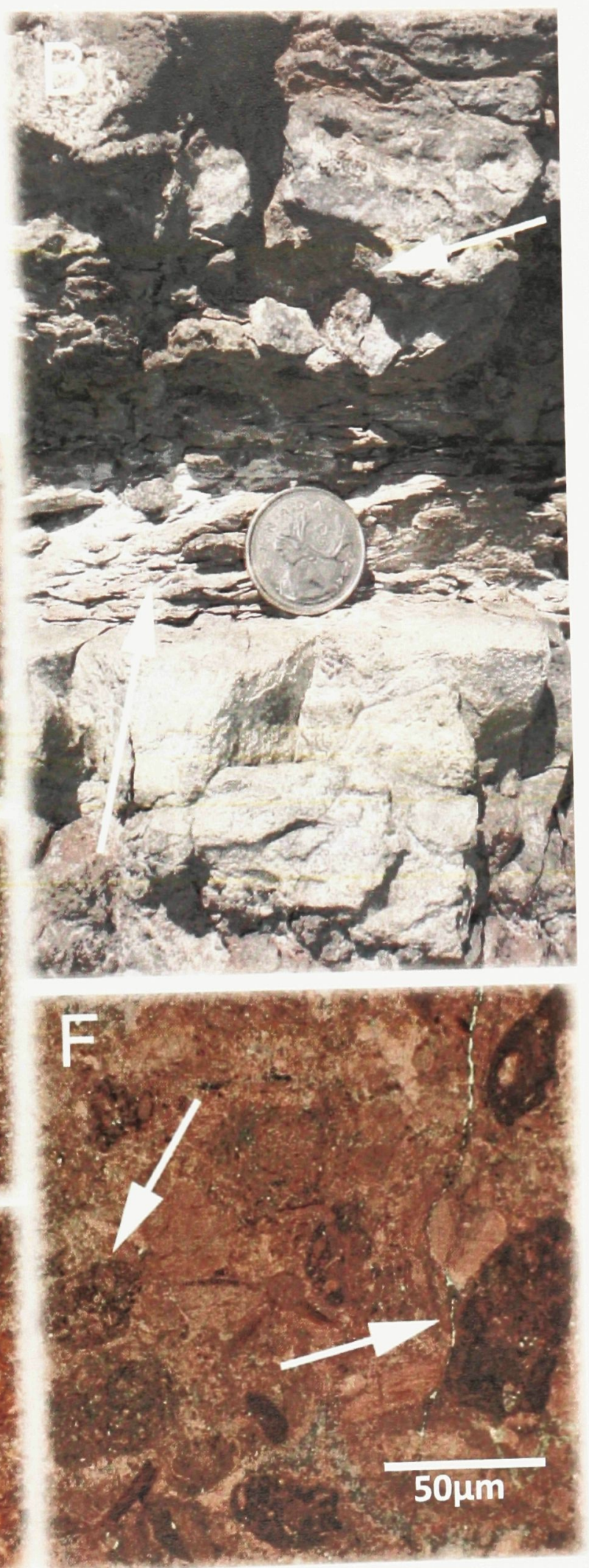
of this subfacies suggests that, along with the presence of crinoid as the predominant fossil type, the setting was subtidal, normal marine, mid-ramp and moderate to high energy. The elevated energy, and likely moving sediment across the seafloor, restricted the impact of infauna to vertical burrows (Brett and Braid 1986; Frey and Pemberton 1984).

\section{C4: Bioclastic floatstone}

This lithofacies contains beds that are generally light grey to grey, and are between 10 and $30 \mathrm{~cm}$ thick. The matrix of the lithofacies range from fine to coarse grained, and consists predominantly of crinoids, bivalves, brachiopods and trilobites along with extraclasts, peloids and indeterminate skeletal fragments which represents about $15 \%$ of the total grain present (Figures $11 \mathrm{E} \& \mathrm{~F}$ ). The diverse faunal assemblage is commonly fragmented. The bedding contacts are typically gradational. The beds are massive with burrows occurring locally. Shaly partings are only locally present. This lithofacies is not common, and was found in the Mint (Locality D) and St. Isidore Quarry (Locality J). Lithofacies attributes identify a normal marine environment, subtidal, mid-ramp of moderate to high energy, but the presence of limestone fragments indicate seafloor lithification (e.g., Location K; Richier quarry) that requires non-deposition allowing, at least, local cementation.

\section{C5: Bivalve/Brachiopod rudstone}

There are two subfacies, both associated with shale of the Eastview Member (Figure 12A). Facies C5a contains beds that are generally dark grey to black, and approximately 
Figure 12. Characteristics of C5 and S1 Lithofacies.

A. Fine-grained limestone (arrow to the left) interbedded with calcareous (S1) to non-calcareous shale (S2). Note the thin beds of bivalve/brachiopod rudstone (C5; arrow to the left). The fine-grained lime-mudstone also occurs as patches within the bivalve/brachiopod rudstones. Locality G.

B. Bivalve/Brachiopod rudstones (arrow). Lithofacies C5. Locality F.

C. Laminated (arrow to the left) and massive calcareous shale (left arrow). Locality G.

D. Massive calcareous shale (S1b; right arrow ) interbedded with patchy calcareous shale (S3). Note the thin beds of bivalve/brachiopod skeletal hash (C5; arrow on the left). Locality E.

E. Massive calcareous shale (S1b; arrow on the right) interbedded with noncalcareous shale (S2; arrow on the left). Locality E. 

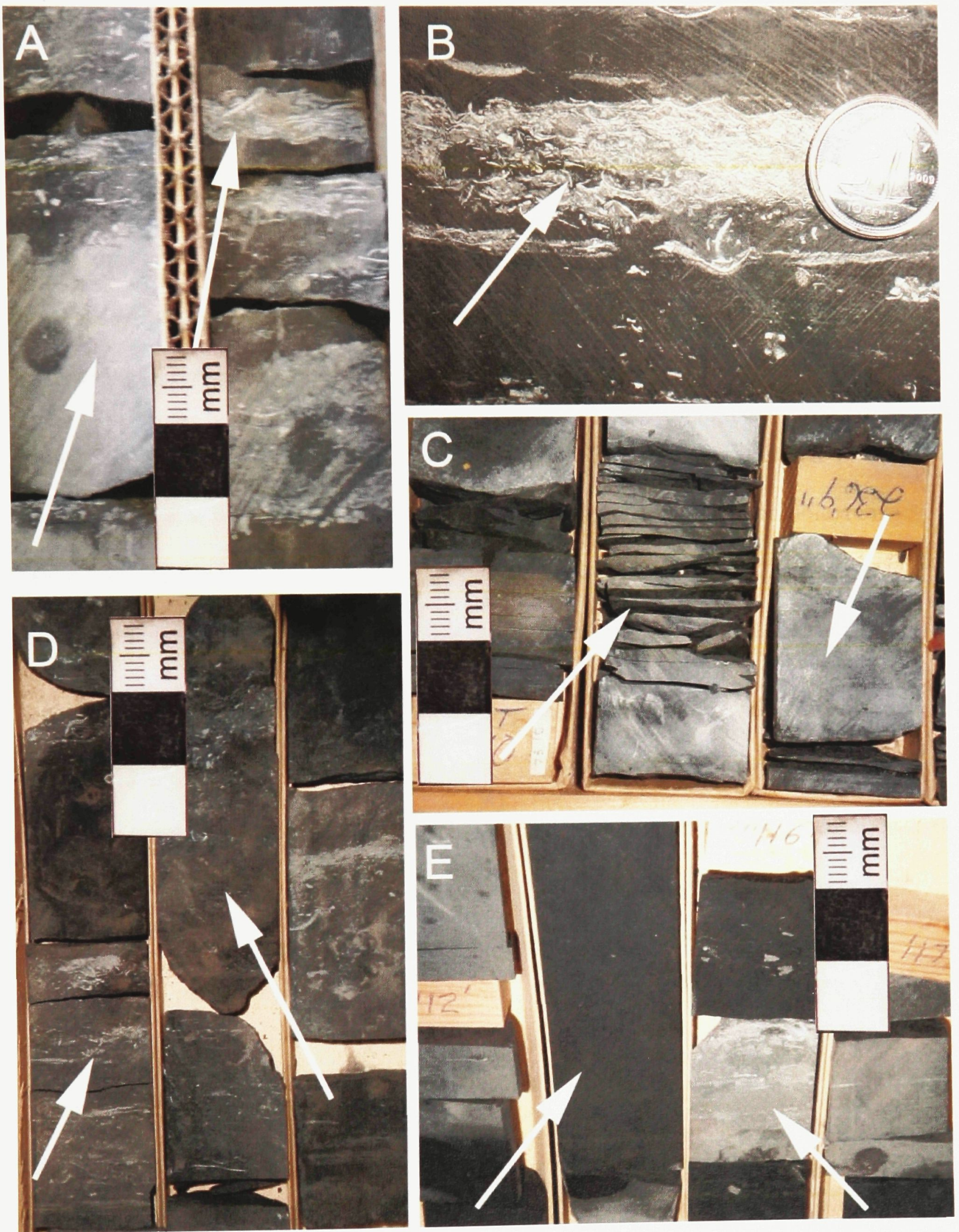
$5 \mathrm{~cm}$ thick. They are massive with bedding contacts generally gradational or erosional.

The matrix is typically fine-grained argillaceous lime mudstone to shale. The predominant fossil types are bivalves and brachiopods, but indeterminate skeletal fragments are also present. Bivalve and brachiopod skeletal remains are usually found whole, and only locally broken. Shells in these lithofacies have no preferred orientation, convex-down or convex-up position, and this usually indicates a slight change in energy level during deposition.

Facies $\mathrm{C} 5 \mathrm{~b}$ is represented by densely compacted skeletal rudstone, with little to no matrix (Figure 12B). The faunal assemblage is similar, but with the addition of trilobite remains. These beds are usually less than $2 \mathrm{~cm}$. They occur within shale, but also form thin cap rock or a limestone pavement to lime mudstone beds interbedded with the shale.

Facies C5a represents an increased abundance of fauna within shale, with a low energy setting. Thus, the change from non-fossiliferous shale to fossiliferous shale appears to require an oceanographic change. Facies $\mathrm{C} 5 \mathrm{~b}$ records fragmentation and condensation that is often typical of sediment lags related to storm deposition or periods of very low sedimentation but high biotic productivity (Brett et al. 2006).

\section{Siliciclastic Facies}

\section{S1: Calcareous shale}

\section{S1a: Calcareous laminated shale}

This subfacies consists of dark to black shale, very fine to fine grained claystone. Shale intervals are 5 to $60 \mathrm{~cm}$ thick, weather recessively, and consist of thin millimeter-scale 
laminations (Figure 12C). Bedding contacts are usually sharp and well defined with basal contacts characteristically sharp. Bivalves, brachiopods and trilobites are common, but not abundant, and form about $50 \%$ of the skeletal grains present. Indeterminate skeletal fragments comprise the rest. Where there is an increase in the abundance of trilobites there is nearly always a visually estimated decrease in diversity of skeletal types preserved. Breakage is minor with most fossils still articulated. Beds are moderately bioturbated but horizontal burrows are present locally (Planolites $s p$ ). These lithofacies are widespread in Eastview Member and occur as thin beds up to $5 \mathrm{~cm}$ interbedded within the Nepean Point Member. The attributes of this lithofacies suggest that shale deposition occurred within a very quiet (low energy) environment (Brett and Baird 1986; Rudwick 1970; Thayer 1975), beyond or exclusive of carbonate depositional conditions.

\section{S1b: Massive calcareous shale}

This subfacies contains beds that are commonly dark brown to black, typically very fine to fine grained, and form intervals and approximately $10 \mathrm{~cm}$ thick. These intervals show no lamination, and may be distinct beds in contrast to the laminations that define lithofacies S1a (Figures 12D \& E). Bedding contacts are usually sharp or gradational and shale beds highly recessive. Fossil types include broken fragments of bivalves, brachiopods, trilobites and indeterminate skeletal fragments; in total, an assemblage composition similar to lithofacies S1a. Horizontal burrows are present locally. The environment of deposition is a low energy setting exclusive of carbonate deposition. Comminuted and disarticulated fossils within shaly intervals commonly indicate low sedimentation rates (Brett et al. 2006). 


\section{S2: Non-calcareous shale}

This lithofacies is composed of dark brown to black shale beds that are very fine-grained. Beds are generally less than $10 \mathrm{~cm}$ thick, and are massive (Figure 12E). Indeterminate skeletal fragments are present, although some portions of the beds have no visible fossils. Bedding contacts are generally sharp and/or gradational. The environment is, like lithofacies S1, of low energy, and exclusive of carbonate deposition (apart from fossils). The non-calcareous nature may be due to an overall absence of very fine-grained fossil material. A notable decrease in fossil content relative to lithofacies S1 may indicate deeper water or less oxygen within the water column (Brett et al. 2006).

\section{S3: Patchy calcareous shale}

This lithofacies combines finely interlaminated to bedded calcareous and non-calcareous shale beds that are dark brown to black. The beds are deeply recessive and are typically claystone. Bedding contacts are sharp and/or gradational. Indeterminate skeletal fragments are locally present but most areas are sparsely fossiliferous. Environment of deposition is a low energy marine environment exclusive of carbonate deposition, and the same environmental conditions as interpreted for S2 may apply here (Brett et al. 2006).

X-ray diffraction has revealed a general mineralogy of calcite, quartz, illite, kaolinite and pyrite for the shale composition, with the calcite content varying according to the abundance of finely communited shell material (Figures 13-15). The three samples were taken from calcareous shale upsection through the Lindsay Formation; that is, base of the 
Page Facing 38

Figure 13. X- ray diffractogram of shale showing the major components (sample from Russell core; Locality G). 


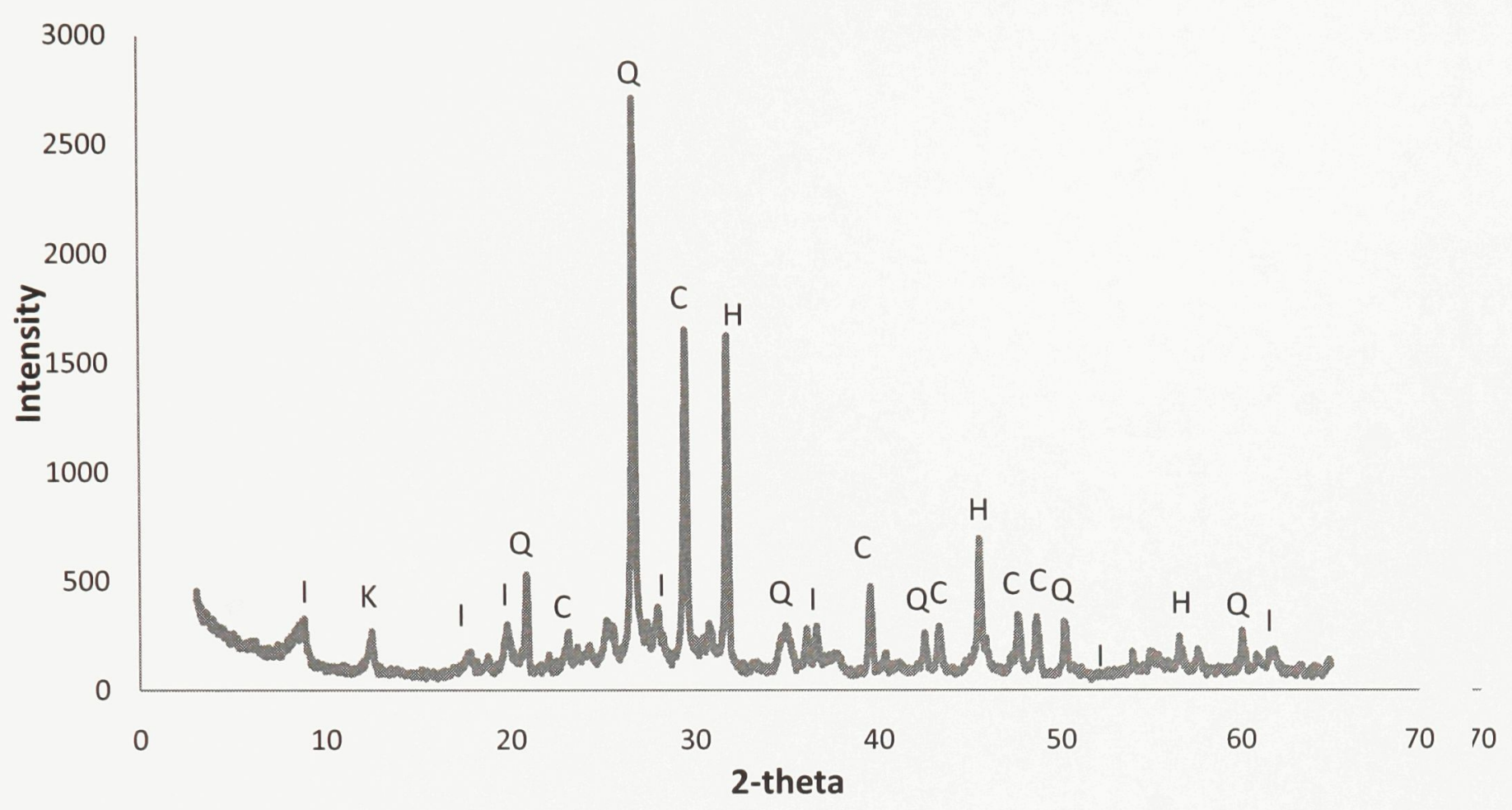


Page Facing 39

Figure 14. X-ray diffractogram of shale showing the major components (sample from St. Isidore quarry; Locality J). 


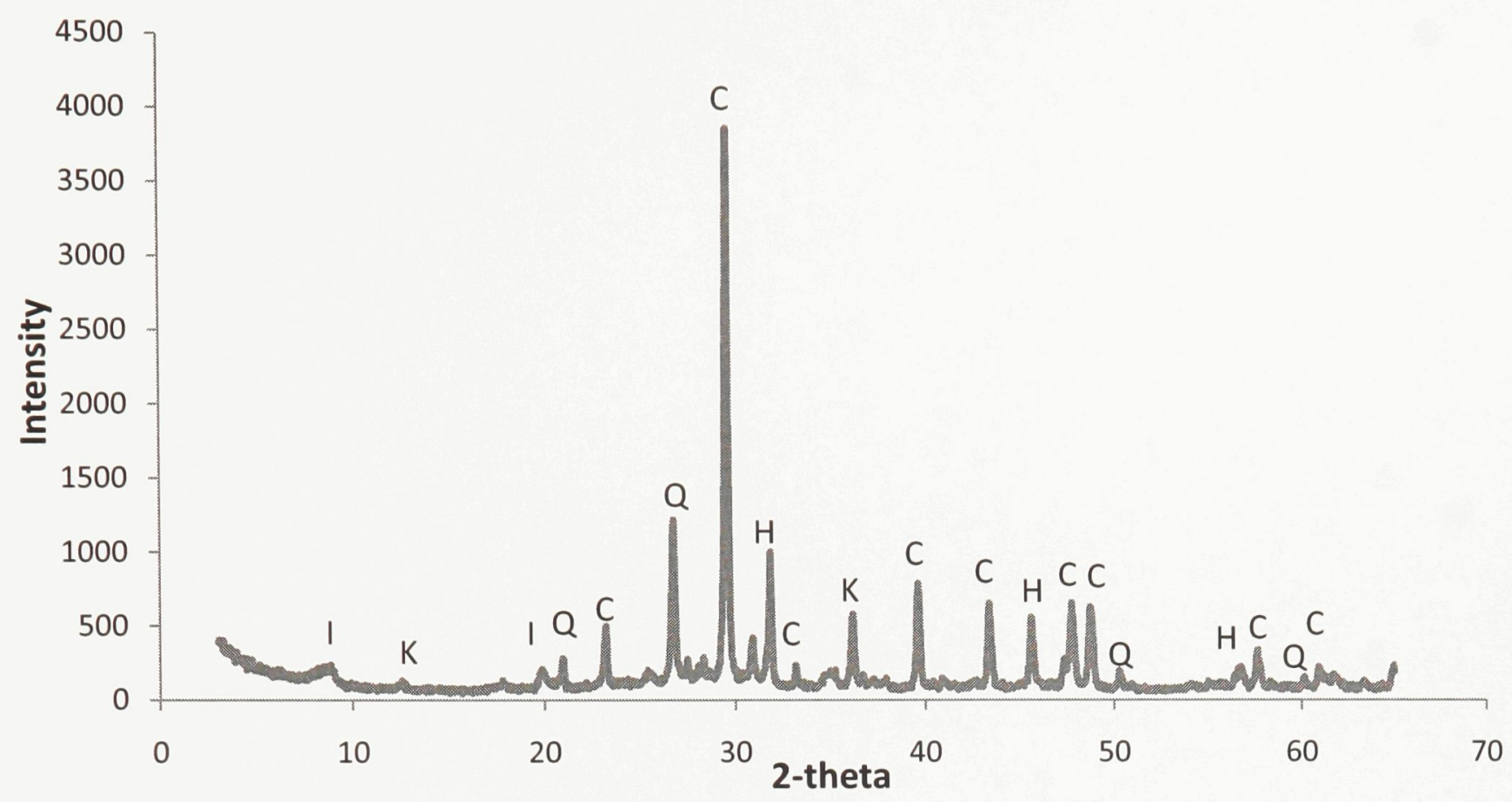


Page Facing 40

Figure 15. X-ray diffractogram of shale showing the major components (sample from Aviation Parkway; Locality F). 


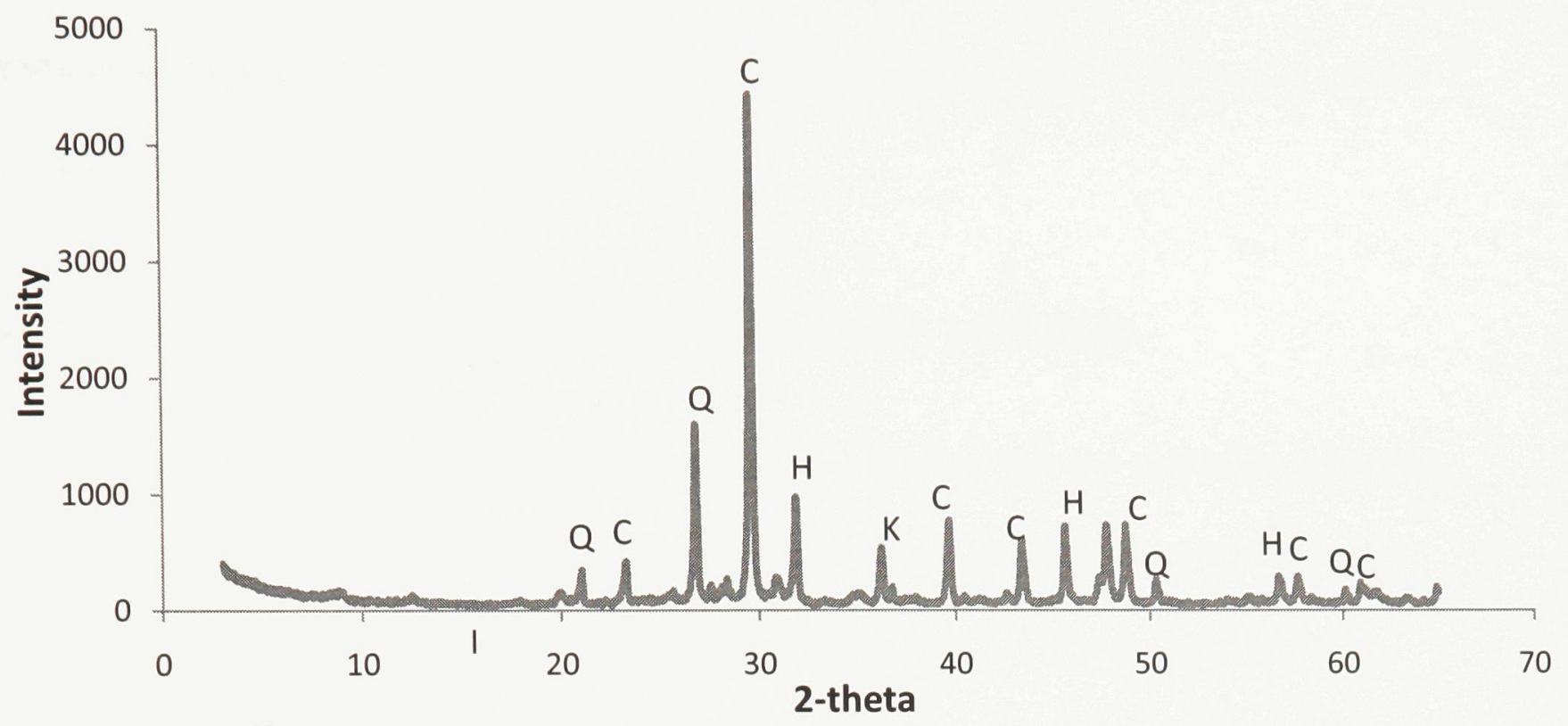


formation (Figure13); midway through the formation (Figure 14); and at the top of the formation (Figure 15).

\section{Regional Intraformational Correlation, eastern Ontario}

Assessment of lithofacies and their abundance demonstrates that the dominant lithofacies producing the characteristic nodular, fine- to coarse-grained, character of the Nepean Point Member of the Lindsay Formation are lithofacies C2 and C3 (Figure 16). In the Ottawa region, both occupy significant thickness of sections, and are best exposed in outcrop below the National Art Gallery adjacent to Nepean Point along the Ottawa River For this reason, the "lower" or "unnamed" member (Williams 1991) is referred to herein as the Nepean Point Member.

East of Russell, $\mathrm{ON}$, the $\mathrm{C} 2$ remains prominent, but $\mathrm{C} 3$ is restricted to fairly thin intervals along with other facies types. There are very few discrete shale beds within the Nepean Point Member. One notable stratigraphic attribute that emerges, though based only on two core localities, is the increase in thickness of the Nepean Point Member moving from the Billings Bridge to Russell core sites, a distance of $\sim 35 \mathrm{~km}$. This difference may be explained in two ways: (1) there is a progressive, gradual thickening moving to the SE from the City of Ottawa through the Russell, ON, region; or (2) there is, somewhere between the two sites, an abrupt change in thickness due to synsedimentary fault control. In both examples increased rate of subsidence in the central part of the embayment is required. 
Page Facing 42

Figure 16. Stratigraphic columns of Localities C to L, showing the distribution of lithofacies and lateral facies changes across eastern Ontario. 


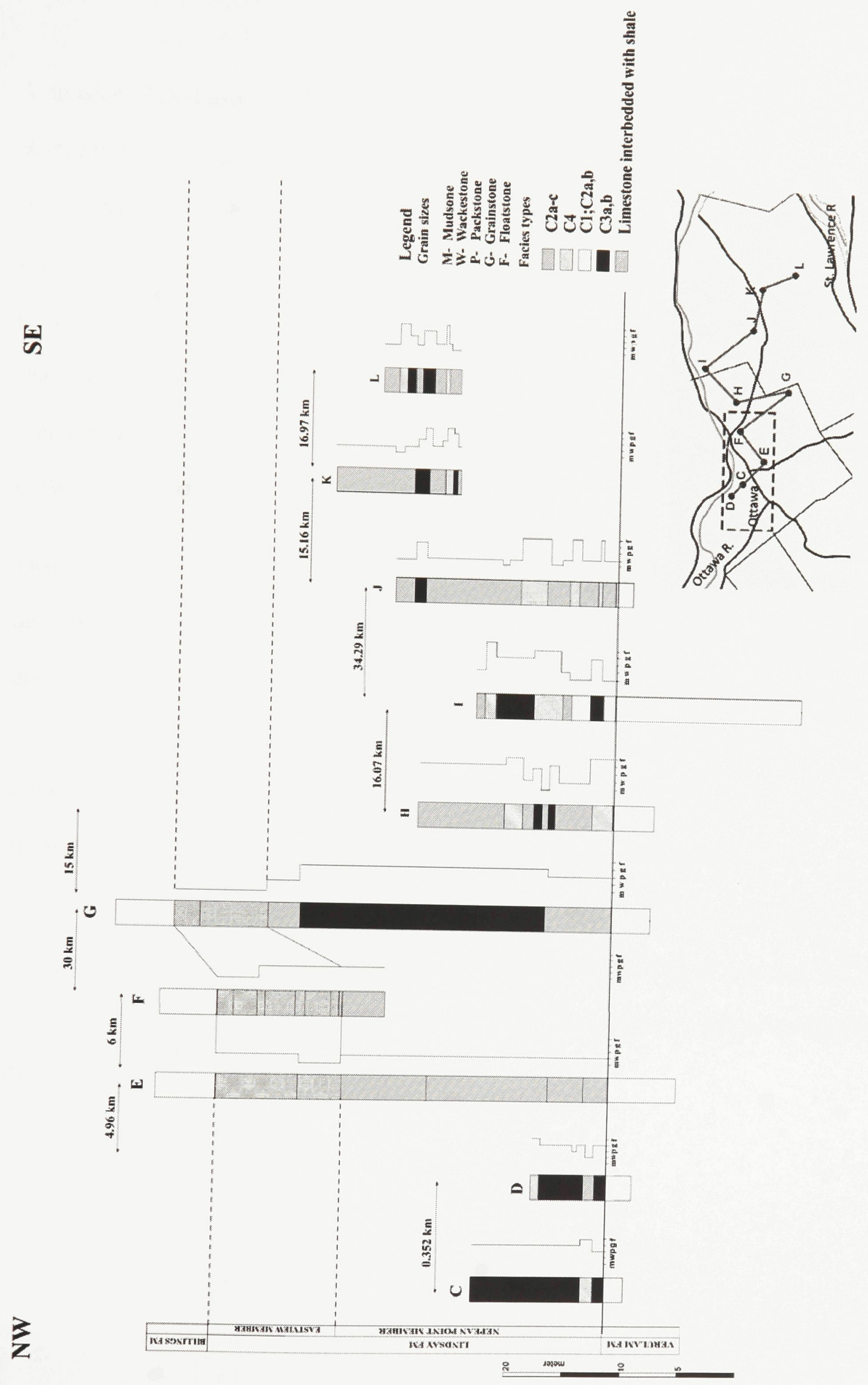


A division of the Eastview Member is established over the distance from the Billings Bridge to Russell regions (Figure 17): (1) a lower nodular, fine-grained limestone succession that corresponds to Facies $\mathrm{C} 2 \mathrm{~b}$; (2) an interval of the fabric that previous workers recognized as the Eastview Member, interbeds of shale and lime mudstone (C2a); and (3) an upper division of fossiliferous shale that includes facies C5. Overall, shale increases in abundance upsection, and both limestone and fossil content decreases, such that the upper $2 \mathrm{~m}$ of the Eastview Member contains sparsely distributed fossils in shale.

Two prominent features emerge from the regional correlation shown in Figure 17. First, there appears to be a slight increase in thickness of the Eastview Member's stratigraphic divisions II and III from the Billings Bridge to Russell cores. Second, divisions IV and V do not appear to be represented in the Russell core. Examinations of the cores do not show any obvious disconformity between the Eastview Member and the overlying Billings Formation. This results in two possible interpretations: (1) that there is a disconformity, but the cores do not allow its recognition; or (2) there was a significant increase in subsidence in the Billings Bridge area relative to that of the Russell core. If the latter, this requires a reversal of the sense of preferred subsidence between the area of the City of Ottawa and central eastern Ontario. 
Page Facing 44

Figure 17. Showing the correlation of the upper (Eastview) Member in eastern Ontario. Localities E, F \& G. 


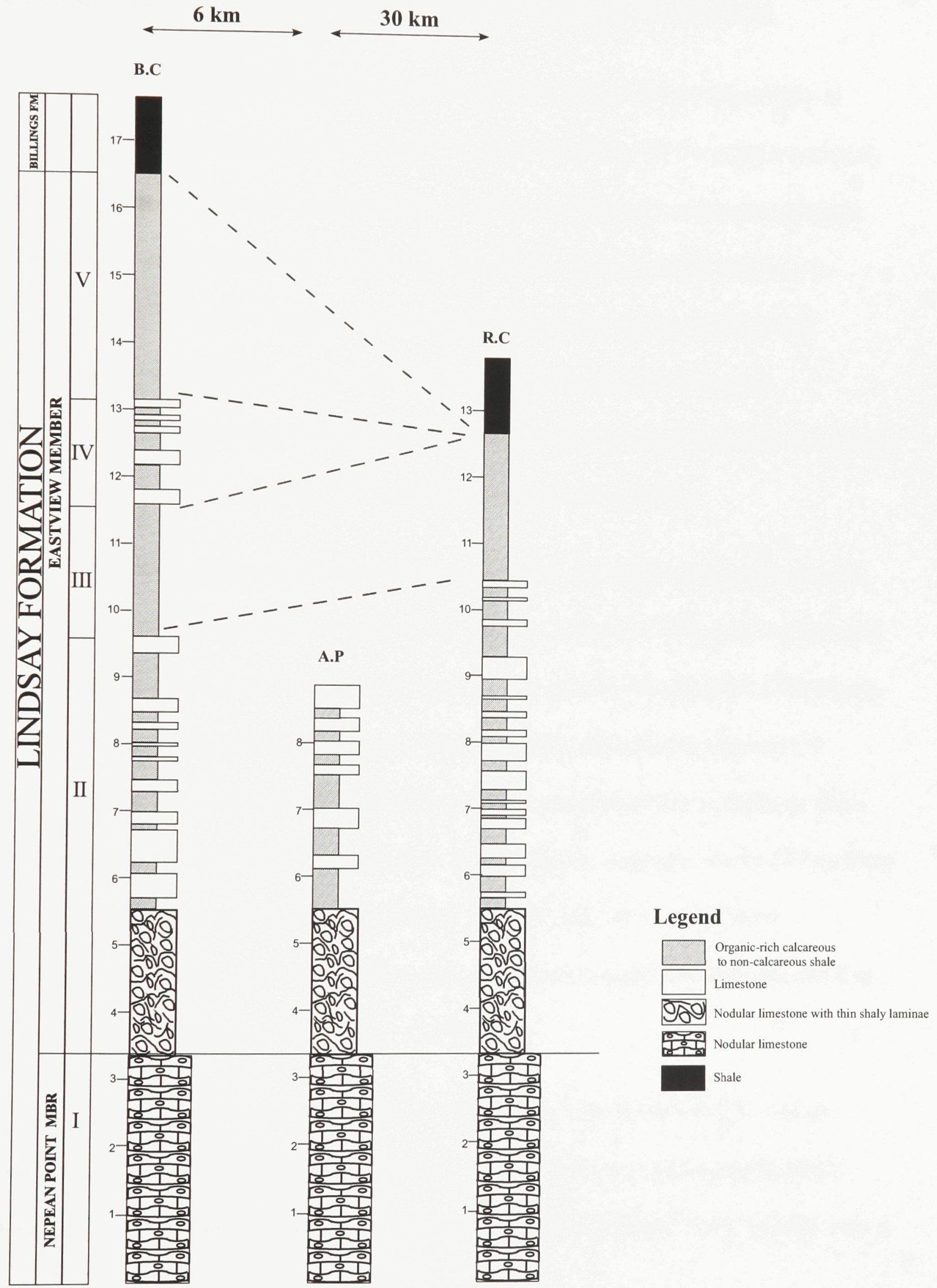




\section{Chemostratigraphy (C, O-isotopes) of the Lindsay Formation}

The organic-rich character of the Eastview Member lends itself to an opportunity to explore if there was oceanographic control on the accumulation of the organic material, and, as a result, influence the geochemistry of the synsedimentary carbonate sediment. This operates in the following manner: rapid burial of organic material will help to increase the ${ }^{13 / 12} \mathrm{C}$ ratio of inorganic bicarbonate because the organic productivity preferentially removes ${ }^{12} \mathrm{C}$. Thus, if the basin in which the Eastview Member accumulated possessed any restriction in circulation with the open ocean, then the micrite facies should show an elevated ${ }^{13 / 12} \mathrm{C}$ ratio (Immenhauser et al. 2003).

Micrite was sampled from both members of the Lindsay Formation in the Russell core, $\mathrm{ON}$ (Locality $\mathrm{G}$ ). The data shows values of $\delta^{13} \mathrm{C}$ range between $0.47 \%$ and $-1.23 \%$, and corresponding values of $\delta^{18} \mathrm{O}$ range between -6.04\%o and -8.14\%o (Appendix IV; Figure 18). The $\delta^{13} \mathrm{C}$ values within the Nepean Point Member remain fairly constant $(\sim 0$ $\pm 1.3 \%$ ). However, within the prominent interbedded shale-limestone succession, there are fluctuations of $<1 \%$ between successive lime mudstone intervals. Above $277 \mathrm{~m}$, there is a prominent negative shift in $\delta^{13} \mathrm{C}$ to about $-1 \%$. Overall, none of the above fluctuations in isotope composition are significant when compared to other limestone in organic-rich successions (Immenhauser et al. 2003).

The $\delta^{18} \mathrm{O}$ trend shows a minimum value at $\sim 286-288 \mathrm{~m}$ with the net shift in isotope composition becoming more negative upsection to this interval, and becoming more positive above this interval. However, within the Eastview Member, there appears to be a 
Page Facing 46

Figure 18. The carbon and oxygen isotopes in the micritic facies of the Lindsay Formation. Localities G \& F. 
Loc. G

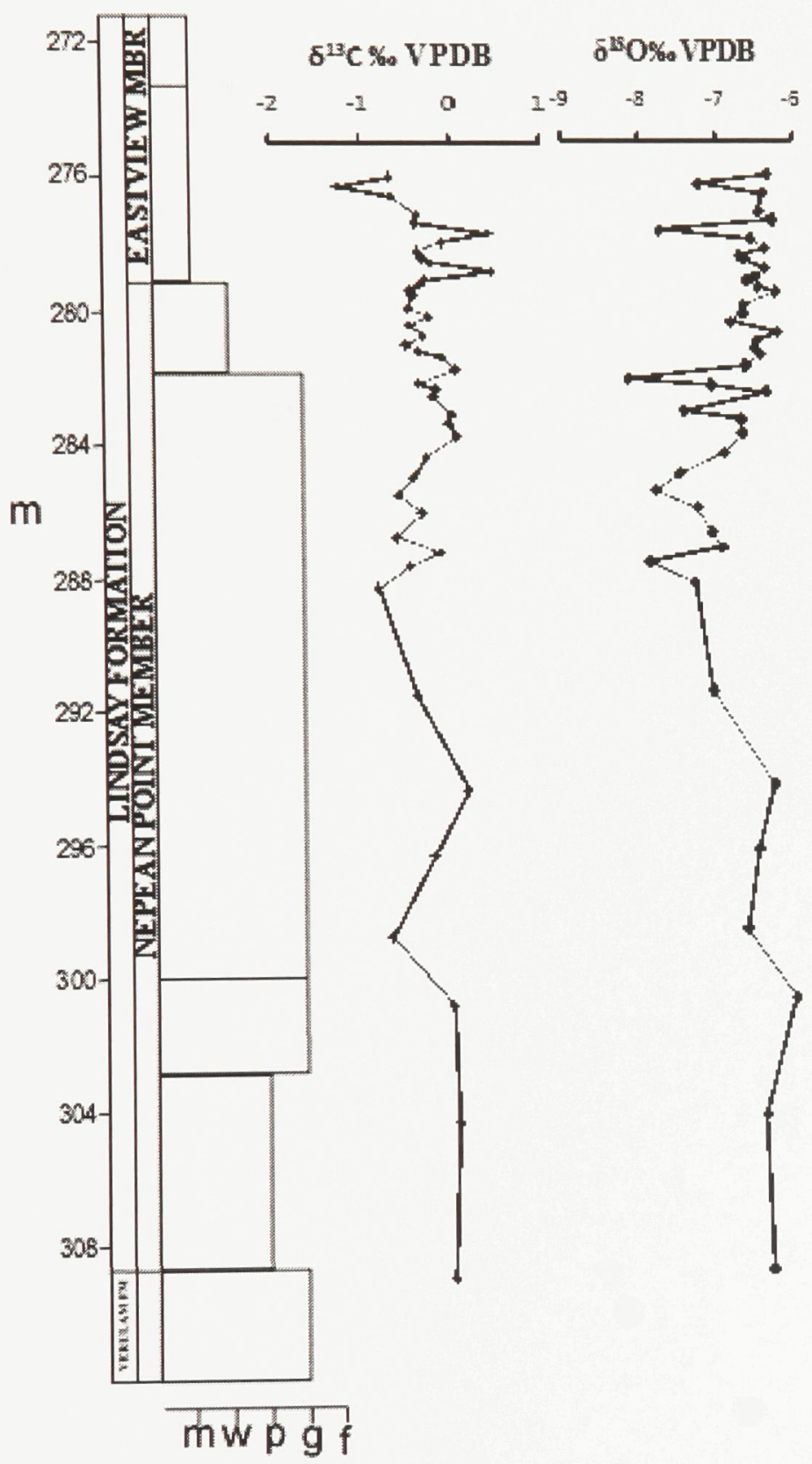

$\delta^{19} \mathrm{C} \%$ VPDB

Loc. F 10
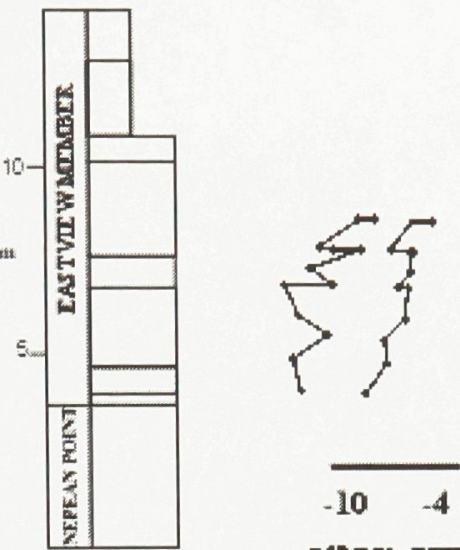

stor vali

\section{Legend}

m- mudstone

w- wackestone

p-packstone

g- grainstone 
relatively constant trend apart from two samples $(\sim 276,278 \mathrm{~m})$ that are up to $1.5 \%$ more negative (Figure 18). The $\delta^{18} \mathrm{O}$ minima may identify an interval of greater diagenetic alteration than above and below (Patterson and Walter 1994).

Micrite was also sampled from the Aviation Parkway site (Locality F; Figure 18 ). $\delta^{13} \mathrm{C}$ and $\delta^{18} \mathrm{O}$ values range from $-0.08 \%$ to $-0.74 \%$ and $-5.17 \%$ o to $-8.4 \%$, respectively. Here, there is a prominent covariance between the two isotopes, both increasing upsection within the Eastview Member. This suggests that both are strongly influenced by diagenetic control, and differ substantially from the record in the Russell core. 


\section{DIAGENESIS AND GEOCHEMISTRY}

\section{Introduction}

The post-depositional diagenetic evolution of the Lindsay Formation in eastern Ontario has not been previously studied. This includes a presentation of the various diagenetic features according to their interpreted diagenetic realm, and their relative timing with regard to burial (Table 4).

\section{Marine Diagenesis}

\section{Burrows}

There are three burrow patterns found in the Lindsay Formation, mostly concentrated in the Nepean Point Member. The Lindsay Formation is prominent for its nodular (bioturbated) fabric for which there is no defined burrow type, just a pervasive mottling throughout the rock. In contrast, some beds have two burrow types which include vertical (Skolithos sp.; Figure 19A) burrows extending down from bedding planes, and horizontal (Planolites sp.) burrows. The calcareous shale (S1) lithofacies contains common horizontal burrows only whereas vertical burrows are abundant in most of the limestone lithofacies. Most of the burrows are filled with dolomite and micrite. Sometimes fine to coarse grained, quartz and some bioclasts are associated with the burrow fill (Figure 19B). Some of the burrows are rimmed with dolomite that has anhedral to subhedral rhombohedral form (Figure 19C). 
Page Facing 49

Table 3. Sequence of diagenetic events as interpreted from petrographic studies of the Lindsay Formation. Dashed lines suggest possible occurrence of diagenetic event in the environment. 


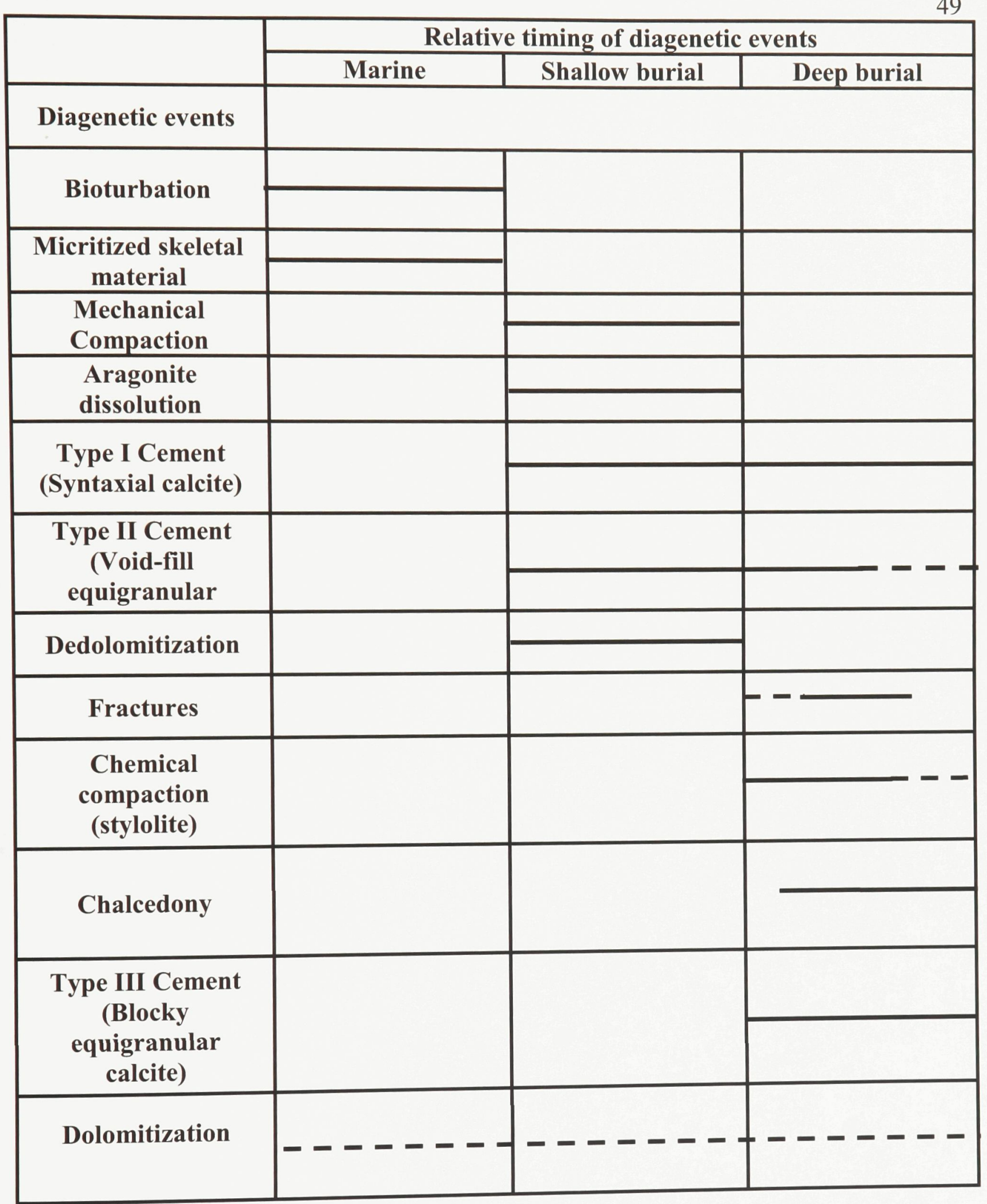


Figure 19. Marine and shallow-burial diagenetic features.

A. Vertical burrows (skolithos sp.). Arrows showing the burrow fabrics that are associated with fine-grained dolomite and micrite. Locality L. x12.5.

B. Photomicrograph (plane polars) of two burrows filled with ferroan stained dolomite and micrite within fine grained peloidal limestone (both arrows). Locality H. x12.5.

C. Photomicrograph (plane polars) of burrow rimmed with ferroan stained dolomite rhombs. Arrows illustrating dolomite rhombs. Locality H. x20.

D. Photomicrograph (plane polars) of micritization around the margin (arrow) and interior of the trilobite fragment likely due to endolithic algae. Locality I. $\mathrm{x} 32$.

E. Photomicrograph (plane polars) illustrating mechanical compaction. Note the skeletal fragment breaking through another skeletal fragment and forming a sutured contact (arrow). Chalcedony being attacked by iron prone cement at the center of the skeletal grain. Locality I. x32.

F. Photomicrograph (plane polars) of aragonite skeletal fragment which had been totally dissolved. The microbial encrustation likely caused by endolithic algae surrounding the lower end of the void filled with ferroan-calcite blocky cement (arrow). The dissolved aragonite fragment is within a skeletal grainstone fabric. Locality I. x12.5.

G. Photomicrograph (plane polars) of skeletal fragments which have been replaced by ferroan blocky calcite (arrow). Note the aragonite skeletal fragments have been totally dissolved. Locality J. x16.

H. Photomicrograph (crossed polars) of echinoderm fragments with syntaxial overgrowth non-ferroan cement (arrow). Note the blocky non-ferroan cement surrounding the syntaxial overgrowth cement. Locality I. x35. 

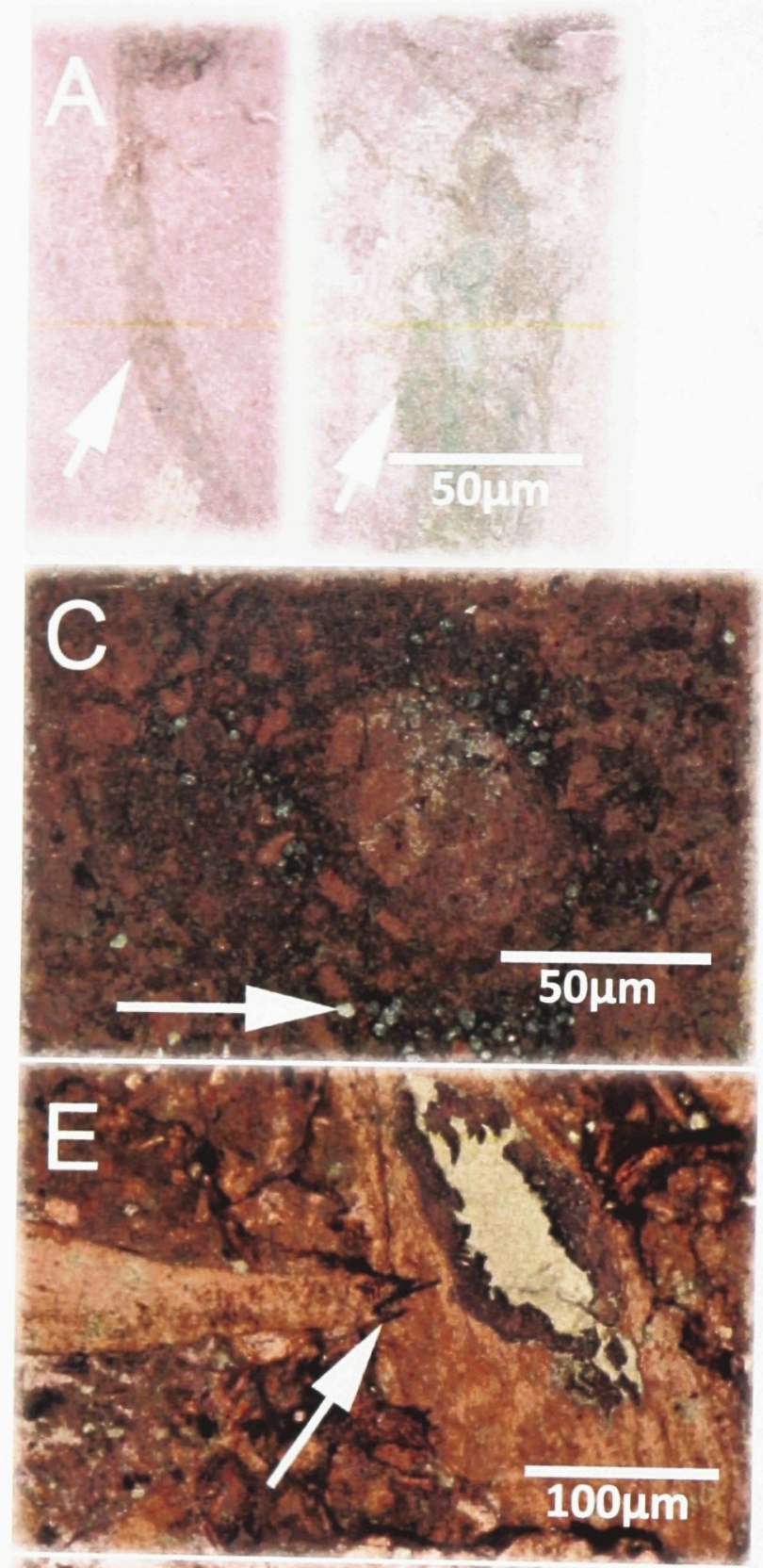

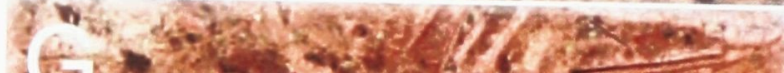

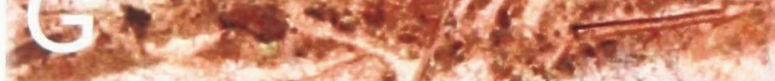

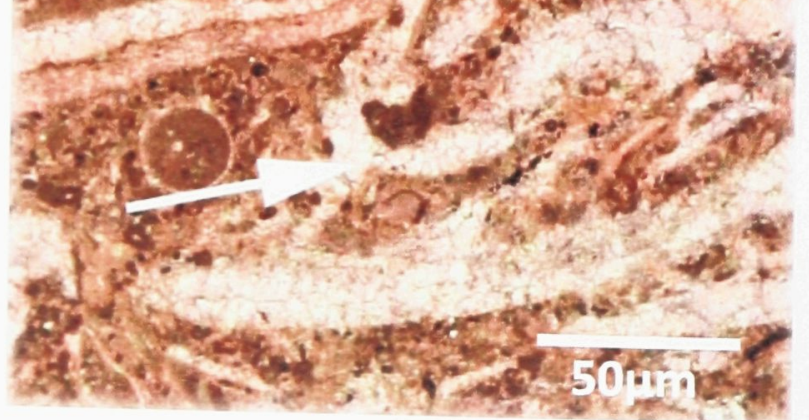
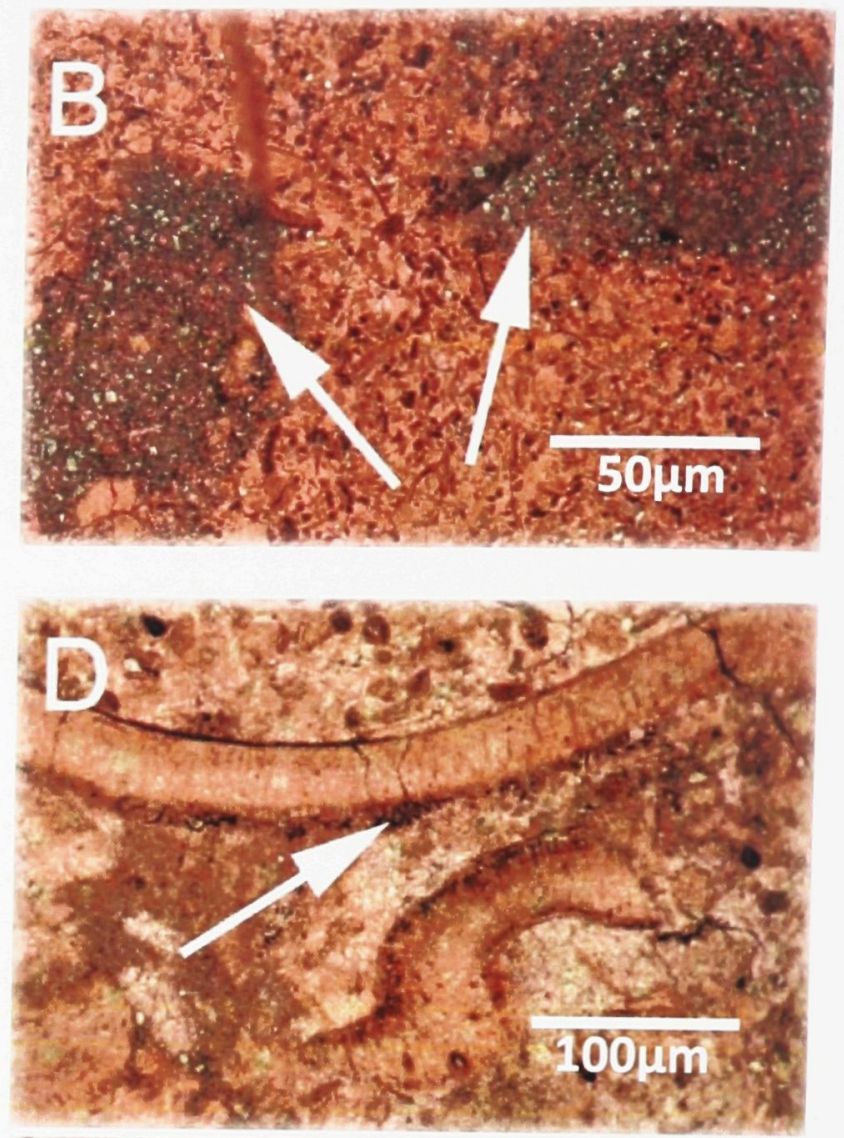
1.

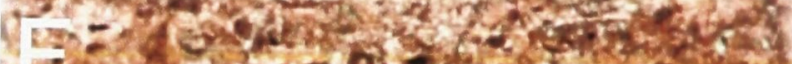

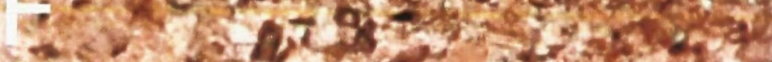

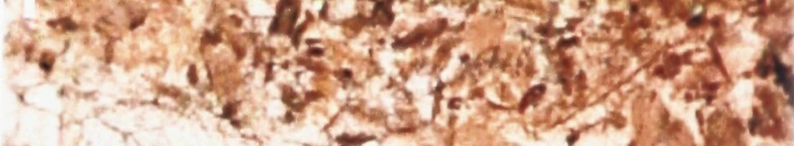

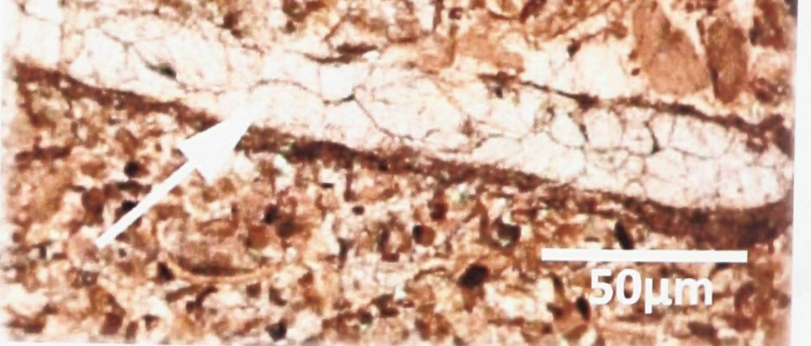

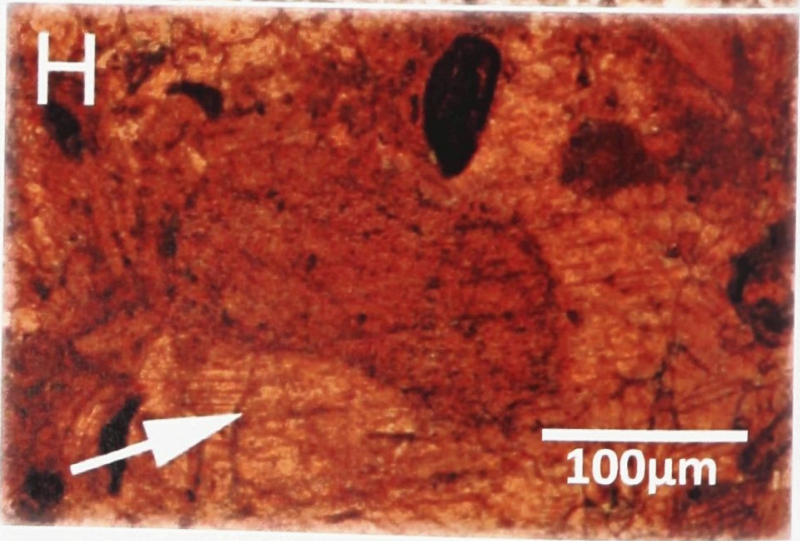




\section{Micritized and Micritic Layers Related to Skeletal Material}

Micrite is associated with skeletal grains in two manners. First, some grain types (e.g., trilobite) show micritized margins and interiors (Figure 19D) that are likely evidence of alteration by endolithic algae (Tucker and Wright 1990). However, more common are discontinuous microlaminae ( 6 to $60 \mu \mathrm{m}$ ) of micrite, often with apparent cellular structure, that produces discontinuous coated grains. These micrite fabrics appear restricted to the Nepean Point Member of the Lindsay Formation. The coated grain fabric illustrates that the skeletal material was resident on the seafloor without immediate burial.

\section{Shallow-Burial Diagenesis}

\section{Mechanical compaction}

The lower part of the Nepean Point Member of the Lindsay Formation shows differential mechanical compaction wherein some parts of the formation show well compacted (e.g., closely juxtaposed grains) fabric in contrast to grains well separated by intergranular cement (Figure 19E). This demonstrates an early history of cementation prior to completion of mechanical compaction. The occurrence of complete mechanical compaction, however, is sparse and this suggests that there was partial lithification in most of the lithofacies before significant (a few metres) burial (James \& Choquette 1990a; Tucker \& Wright 1990; Flügel 2004). Mechanical compaction begins soon after deposition and strain is concentrated at grain contacts which can ultimately account for much of the thickness reduction in carbonate sequences (Flügel 2004). The increase in pressure as sediments are buried can lead to breaking of the grains (Scoffin 1987). 
Within the Eastview Member, the shales had likely undergone significant early compaction and reduction in porosity loss within the first few meters of burial (Baldwin 1971). The effect of such mechanical compaction is evident in the lower Eastview member where shale laminae wrap around limestone nodules indicating early formation of the nodules prior to completion of mechanical compaction.

\section{Aragonite dissolution}

Aragonite is extremely prone to dissolution in pore waters which eventually leads to the formation of fabric-selective porosity (Tucker \& Wright 1990). As such, the majority of the aragonitic shells undergo total dissolution (Figure 19F). The Lindsay lithofacies do not preserve original aragonite fossils nor evidence that calcite replaced aragonite. The fossils do not contain any preserved relic skeletal microstructure. What appears to have happened in the Lindsay Formation is that the original aragonite fossils dissolved, and the voids produced were filled with cement (Figure 19G). Diagenetic fabric shows that aragonite dissolved after formation of at least some intergranular cement, otherwise the void spaces would not be preserved. Most of the bioclasts present in the Lindsay Formation were originally composed of low-Mg calcite. Consequently, the effects of aragonite dissolution are minimal.

\section{Type I Cement: Syntaxial calcite}

Iron-poor (based on staining and microprobe analysis; see Appendix IV) syntaxial overgrowth cement occurs associated with echinoderm fragments in most of the coarsegrained limestone lithofacies (Figure 19H). Syntaxial overgrowth is a common feature of 
grainstones containing echinoderm fragments (Tucker and Wright 1990). Syntaxial overgrowth formation post-dates the formation of burrows, and locally occurs contemporaneous with mechanical compaction, impeding reduction in porosity (Figures $20 \mathrm{~A} \& \mathrm{~B})$. It is finished prior to completion of mechanical compaction and aragonite dissolution. This is compatible with documentation from other sources with regard to typical early diagenetic conditions (James and Choquette 1990b; Tucker and Wright 1990).

Microprobe analysis confirms that the iron content of the syntaxial overgrowth cement is generally below the minimum detection limit (Appendix IV). The syntaxial overgrowth cement generally has a dull to bright luminescence.

\section{Type II Cement: Void-fill equigranular calcite}

This cement occupies intra- and intergranular porosity and moldic pores (i.e., leached aragonitic skeletal fragments of bivalves and gastropods). This cement type consists of coarsely crystalline anhedral, blocky and clear calcite. This cement type stains a pink colour (Figure 20C), and has a dull-luminescence with minor bright zones. This cement type postdates Type 1 cement and pre-dates Type III cement, which is ferroan. It also predates fracture development, this space filled by Type III calcite cement. Type II cement is present in most of the limestone lithofacies of the Lindsay Formation. 
Figure 20. Shallow and deep burial diagenetic features.

A. Photomicrograph (plane light) of echinoderm fragments totally surrounded by syntaxial overgrowth (arrow). Locality J. x8.

B. Photomicrograph (plane light) illustrating porosity within the skeletal limestone fabric of the Nepean Point Member. Note the syntaxial overgrowth surrounding the echinoderm fragments. Arrow showing the ferroan calcite cement filling the remaining pore spaces. Locality K. x8.

C. Photomicrograph (plane light) of echinoderm fragments and skeletal grains embedded. Arrow showing non-ferroan blocky calcite cement. Locality I. x25.

D. Photomicrograph (plane light) of skeletal fragment totally dissolved out and replaced with non-ferroan (arrow) and ferroan blocky calcite cement. Note that the skeletal fragments are embedded within a fine grained matrix. Locality $\mathrm{H}$. $\mathrm{x} 12.5$.

E. Photomicrograph (plane light) of a vertical fracture (arrow) terminating with depth. The fracture is cross-cutting low angle cross beds. Note that the fracture is filled with ferroan calcite cement. Locality I. x8.

F. Fracture ( $\sim 2 \mathrm{~mm}$; arrow) cutting across fine grained limestone. Note that fracture is filled with ferroan calcite cement. Locality F. x20.

G. Photomicrograph (plane light) of sub-horizontal stylolite (arrow at the top of photograph) and fracture filled with ferroan calcite cement (arrow at the bottom) Note that the stylolite and fracture are perpendicular to the low-angled cross beds. Locality I. x16.

H. Photomicrograph (plane light) of void spaces filled with ferroan and non-ferroan blocky calcite cement (arrow at the bottom). Note the shelter porosity (arrow at the top) and the fine-grained sediments within a coarse-grained matrix. Locality I. $\mathrm{x} 5.8$. 

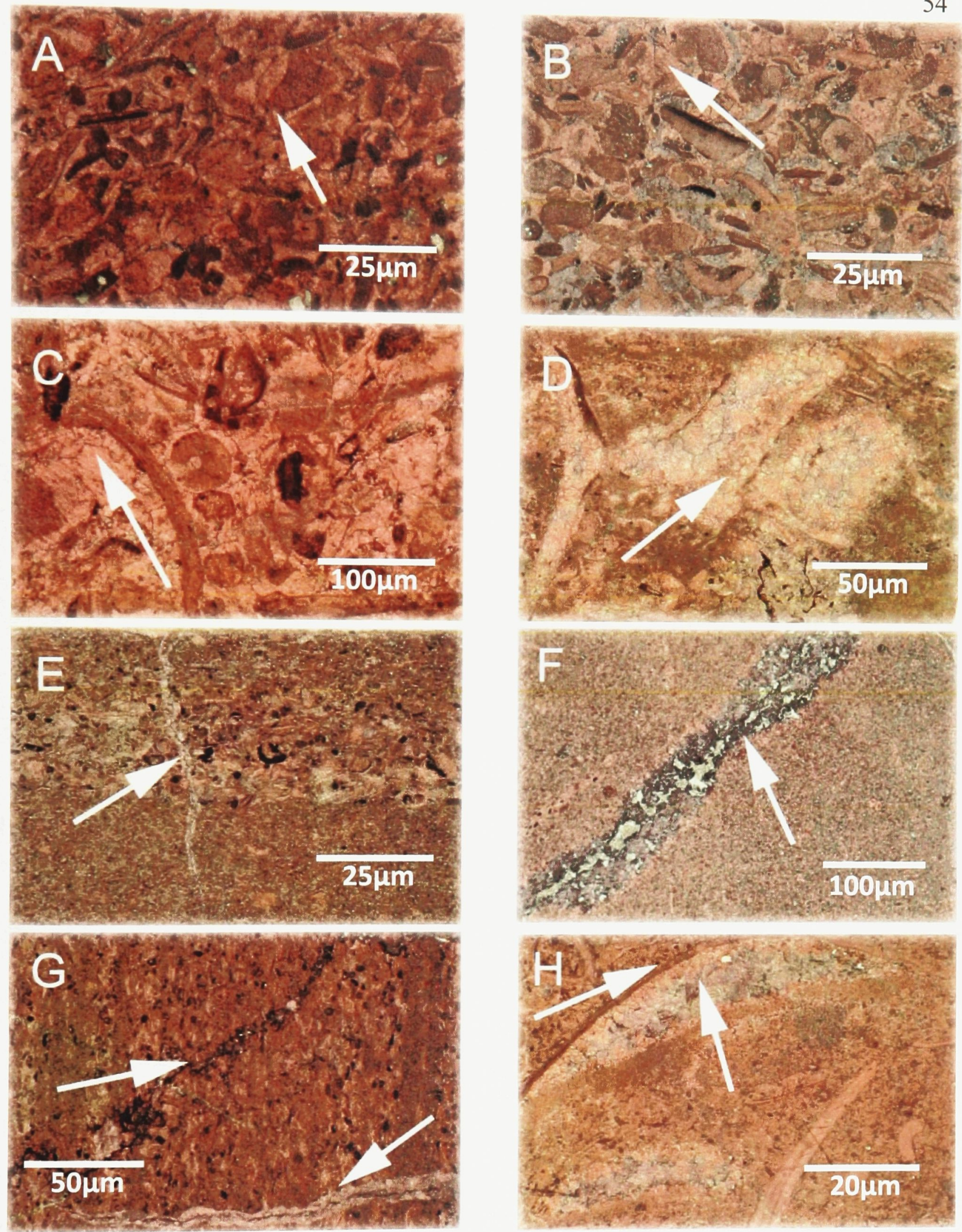
However, it occurs most frequently in the medium to coarse-grained lithofacies of the Nepean Point Member.

Blocky, clear and non-ferroan calcite spar is characteristic of early burial cement in most limestones (Figure 20D), and may possess a variety of patterns of dull to bright luminescence as a function of the Fe and Mn concentration of the pore waters (Tucker \& Wright 1990).

\section{Deep-Burial Diagenesis}

\section{Fractures}

Microfractures of sub-millimetre to few millimetres in width (Figures 20E \& F) are found within the Lindsay Formation. The fractures are filled with the Type III cement. Generally, the fractures post-date every diagenetic event except Type III cement and stylolites. Sub-horizontal to vertical stylolites are observed to cross-cut the ferroan calcite filled fractures (Figure 20G). Calcite veins of centimeter width also crosscut the Lindsay Formation, contain ferroan calcite (Dix and Robinson 2003), and represent larger fracture systems. Their timing brackets formation of burial stylolites (Dix and Robinson 2003).

\section{Type III Cement: Blocky equigranular calcite}

This cement fills remaining intergranular, intragranular, moldic, shelter and fracture porosity within the Lindsay Formation (Figures $20 \mathrm{H} \& 21 \mathrm{~A}$ ). This cement type is similar petrographically to the Type II cement but stains purple due to increased abundance of 
Figure 21. Deep burial diagenetic features (I).

A. Photomicrograph (plane light) of echinoderm fragments embedded within blocky ferroan calcite cement. Arrow showing syntaxial overgrowth cement around some of the echinoderm fragments. Porosity totally filled by blocky, ferroan calcite cement. Locality H. x35.

B. Photomicrograph (plane light) of a gastropod fragment totally dissolved and the interior replaced with dolomite rhombs and micrite. Arrow illustrating blocky, ferroan calcite cement surrounding the dissolved gastropod fragment. Locality J. x5.8.

C. Photomicrograph (plane light) of porosity totally filled blocky, ferroan calcite cement (arrow). Note the previous skeletal fragment has been totally obliterated. Locality I. $\mathrm{x} 12.5$.

D. Photomicrograph (plane light) of gastropod fragment and the interior of the gastropod with geopetal fill. Arrow showing drusy cement pattern. Locality F. x5.8.

E. Photomicrograph (plane light) of the interior of a skeletal fragment being replaced by silica (chalcedony) and the chalcedony being attacked by ferroan calcite cement (arrow). The chalcedony pre-dates the ferroan calcite cement and post-dates the nonferroan cement. Locality I. x32.

F. Photomicrograph (plane light) of ferroan dolomite rhombs. The dolomite is found within burrows. Note the clay material embedded between the ferroan dolomite. Locality K. x35. 

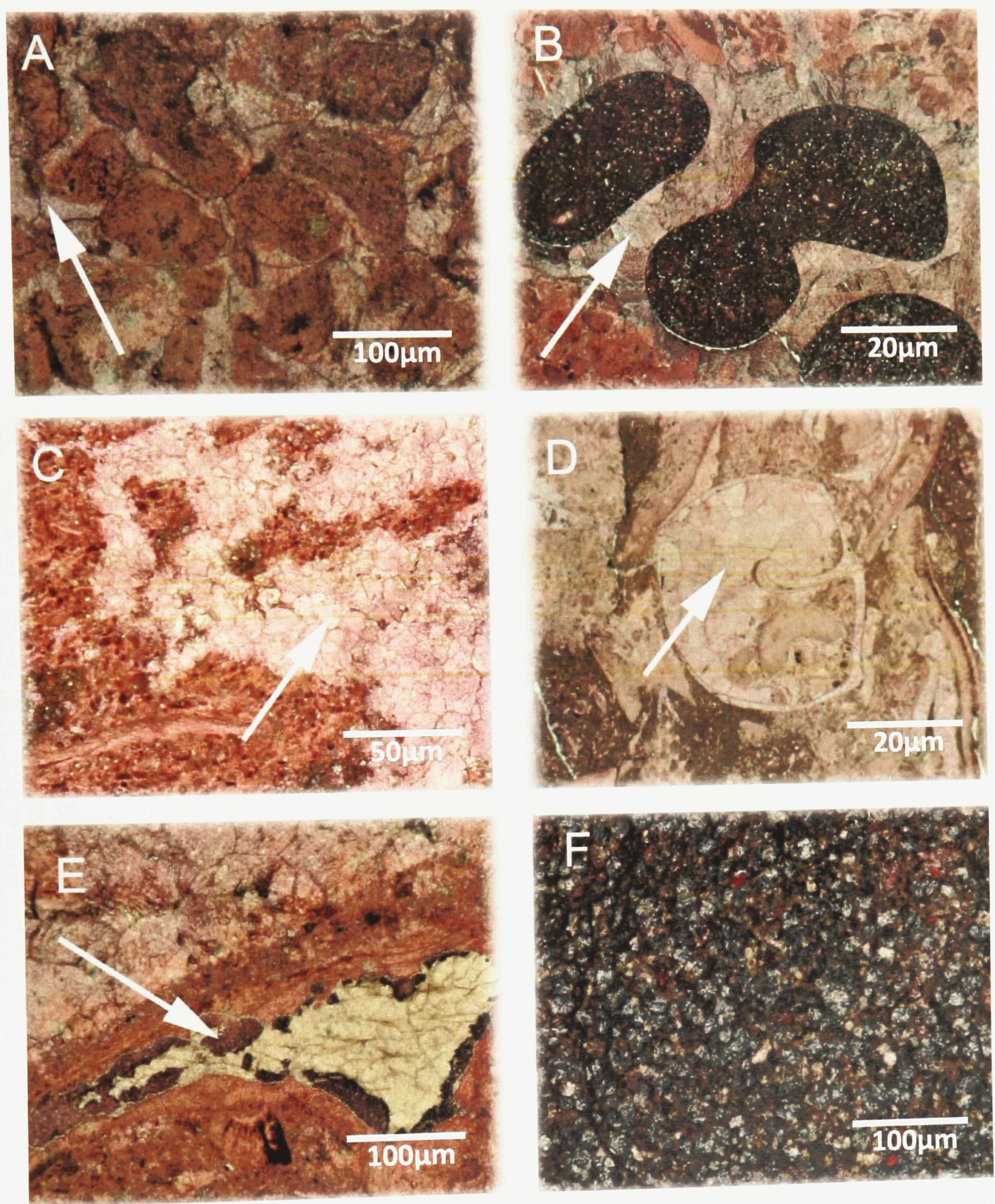
iron (Figures 21B-D; Appendix IV). Locally, Type III cement replaces patches of chalcedony (Figure 21E). Type III calcite cement possesses a dull to bright luminescence.

\section{Chemical compaction}

Horizontal stylolites are present in the Nepean Point Member and cross-cut sedimentary fabric, grain boundaries, and all types of cement (see Figure 8E). These stylolites postdate all diagenetic features in the Lindsay Formation. The majority of the stylolites are characterized by a thin sinuous $(2 \mu \mathrm{m})$ concentration of insoluble material along an irregular surface. Some of the stylolites have a concentration of fine-grained quartz and occasionally euhedral to subhedral dolomite rhombs. Abundant non-sutured seams occurring as wispy laminae are found to wrap around nodules in the Nepean Point Member. Horizontal stylolites are evidence of chemical compaction due to overburden pressure; that is, after several hundred meters of burial (Tucker and Wright 1990). There is also a family of sub-vertical stylolites that occur within the Lindsay Formation. These cross-cut bedding planes at a high angle, and are indicative of lateral tectonic stress (Wanless 1979). Within the Ottawa Embayment, there are numerous faults of normal and strike-slip origin, the latter likely the cause of the horizontal stress.

\section{Dolomite}

Fine to coarse-grained dolomite occurs in some of the lithofacies. The dolomite rhombs are commonly subhedral to euhedral (planar-e to planar-s; Sibley and Gregg 1987) in form, locally producing patches of interlocking crystal mosaics but also occurring as 
isolated rhombs floating within the limestone matrix. The following is typical of the majority of dolomite, regardless of origin. First, it is mostly ferroan, as indicated by a blue stain (Figure 21F). Microprobe analysis reveals that $\mathrm{Na}, \mathrm{Ba}$, and $\mathrm{Sr}$ contents are typically below the detection limit (Appendix IV). However, cathodoluminescence (using the microprobe) illustrates a strong zonation of a complex iron-poor zonation within the core, and a Fe-rich microzoned rim that makes up most of the area exposed (Figure 22). In thin section, using a cathodoluminescope, the same thing is observed, but the Fe-poor "cores" represent $\sim 10 \%$ of a section, whereas most of the dolomite is ferroan and microzoned. Thus, there is, overall, a two-step production of dolomite, the Fe-rich phase being the most dominant.

The Fe-poor cores of the dolomites are unusual in that there is often a rounded, dark nonluminescent centre which is reminiscent of "inside- out" dolomite (Jones 2007). The rounded central portion appears to represent filled paleoporosity as a result of the dissolution of the original core (Figures 23A \& B).

The general core-to-rim zonation observed in the Lindsay Formation a typical diagenetic pattern associated with burial diagenesis of many carbonate successions (Choquette and James 1987). But if the original core dissolved, this means that iron-poor dolomite has filled the secondary intracrystalline porosity prior to the later ferroan dolomite. 
Page Facing 59

Figure 22. Showing the increasing values of the content of $\mathrm{FeO}(\mathrm{wt} \%)$ through a transect in the dolomite rhomb from core to outermost rim. 

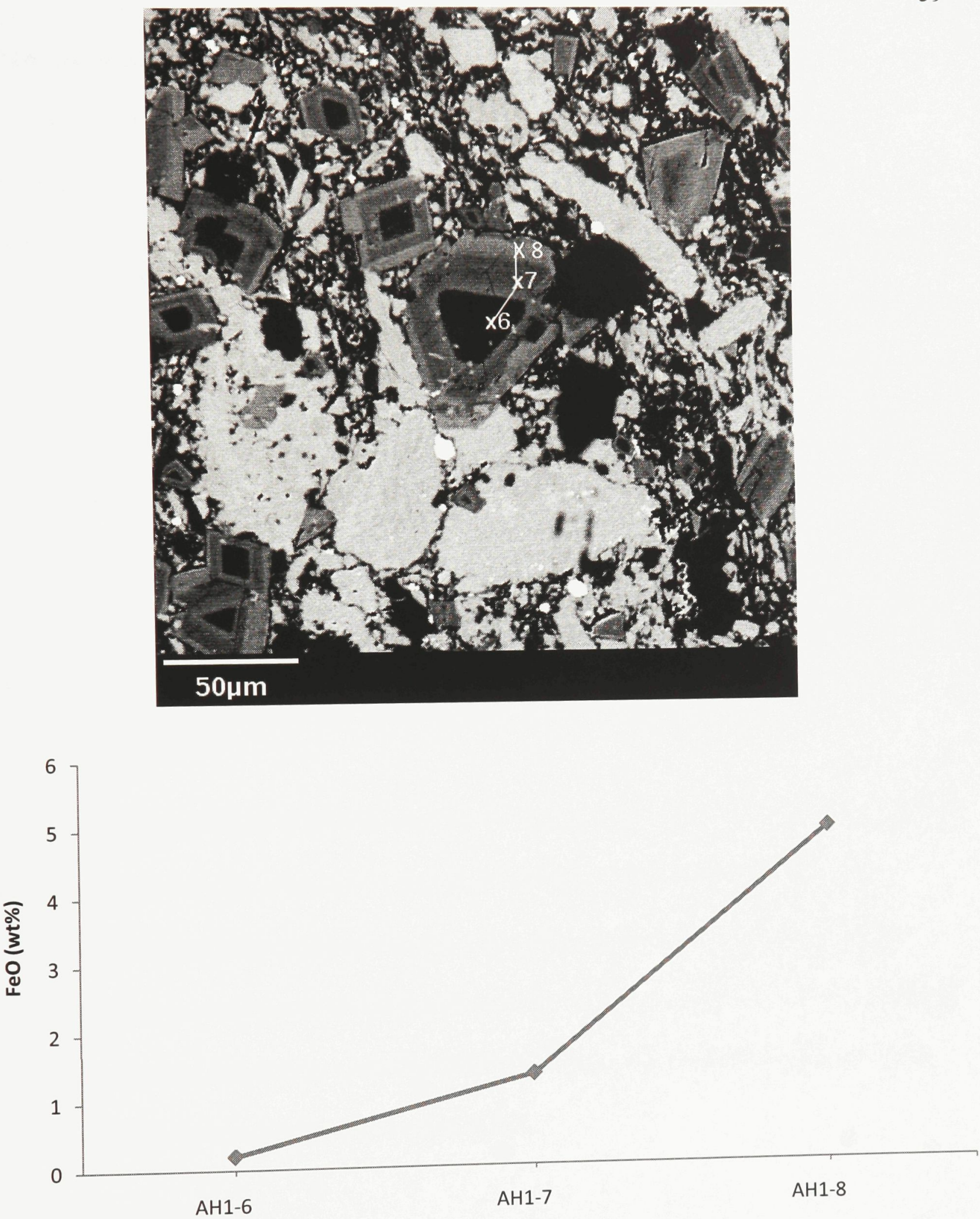
There are three stratigraphic associations connected with dolomite formation.

Burrow-Fill Dolomite. This type of dolomite is found in close association with fine grained, clay-rich material and some skeletal fragments (see Figure 19B). The dolomite rhombs shows the above stated zonation. Very often burrow-fill dolomite is considered a shallow-burial product, $\mathrm{Mg}$ supplied by seawater migrating through the burrows from the seafloor (Tucker and Wright 1990). However, there is no evidence that the majority of burrow dolomite in the Lindsay Formation predates stylolitization, which is common by 250 m (James and Choquette 1990c).

Dolomite with Type III cement. Dolomite occurs in association with Type III iron-bearing cement. The dolomite, in this case, forms rhombohedra scattered within Fe-bearing cement (Figure 23C).

Dolomite along stylolites. Dolomite found in close association with stylolites tends to be non-ferroan, rather than ferroan, but has a dull luminescence (see Figure $8 \mathrm{E}$ ). The association with stylolites indicates timing in response to chemical compaction, and reveals a likely association with fluids generated during deep $(>250 \mathrm{~m})$ burial of the host carbonate. In most limestones, scattered dolomite rhombs occurring along stylolites are common forms of burial dolomite (Tucker 1981).

\section{Dedolomitization}

Dedolomite is formed through leaching of $\mathrm{Mg}$ from the dolomite lattice to produce calcite that preserves the original crystal shape of the dolomite (Figures 23D). This 
feature was recognized only in one section, from burrow-fill dolomite (in abundant clay) within the Nepean Point Member within Canaan Quarry (Locality H) in eastern Ontario. The process of dedolomitization usually takes place at or near the earth's surface (Lee and Harwood 1989). 
Figure 23. Deep burial diagenetic features (II).

A. Microprobe photograph showing the interior of the dolomite iron-poor core which has been dissolved (arrow to the right). An iron-rich microzoned rim (arrow to the left) makes up most of the area exposed. Photograph may also indicate "insideout" dolomite.

B. Microprobe photograph which may also indicate "inside-out" dolomite. Note the inner darker iron-poor core in Figure A has a thin fracture running through it (at $\mathrm{X} 1$; arrow on the top) and an iron-rich microzoned outer rim.

C. Photomicrograph (plane light) of ferroan dolomite rhombs (arrow to the left) within ferroan calcite cement (arrow to the right). Note the skeletal fragments present within the matrix. Locality I. x35.

D. Photomicrograph (plane light) showing dedolomitization. Arrow illustrating dolomite rhomb replaced by non-ferroan calcite. Locality I. x32.

E. Photomicrograph (plane light) illustrating paleoporosity. Note the available pore spaces totally filled with ferroan calcite cement, fine-grained sediments and peloidal fabric. Locality K. x6.25.

F. Photomicrograph (plane light) showing porosity. Arrows showing ferroan calcite cement filling void spaces and embedded within coarse-grained echinoderm fragments. Also note the syntaxial overgrowth cement surrounding the echinoderm fragments. Locality K. x8. 

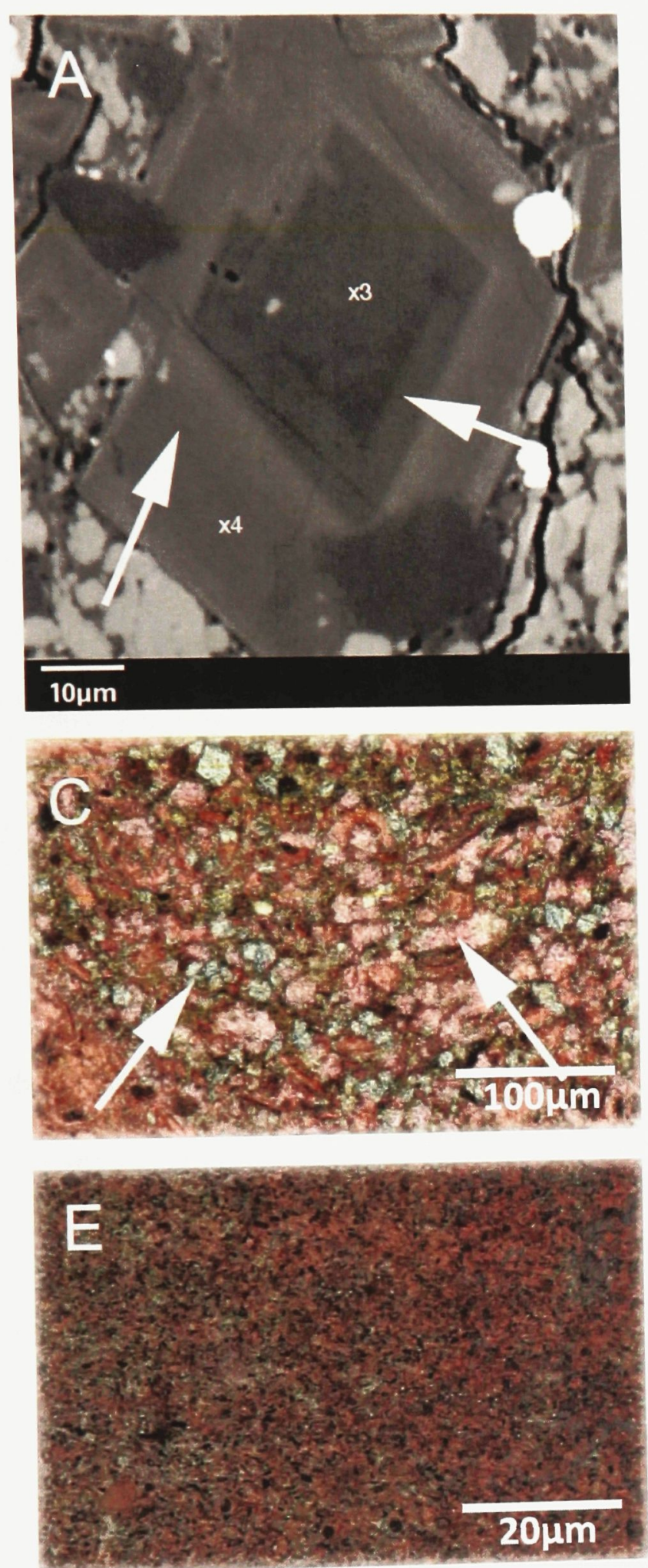
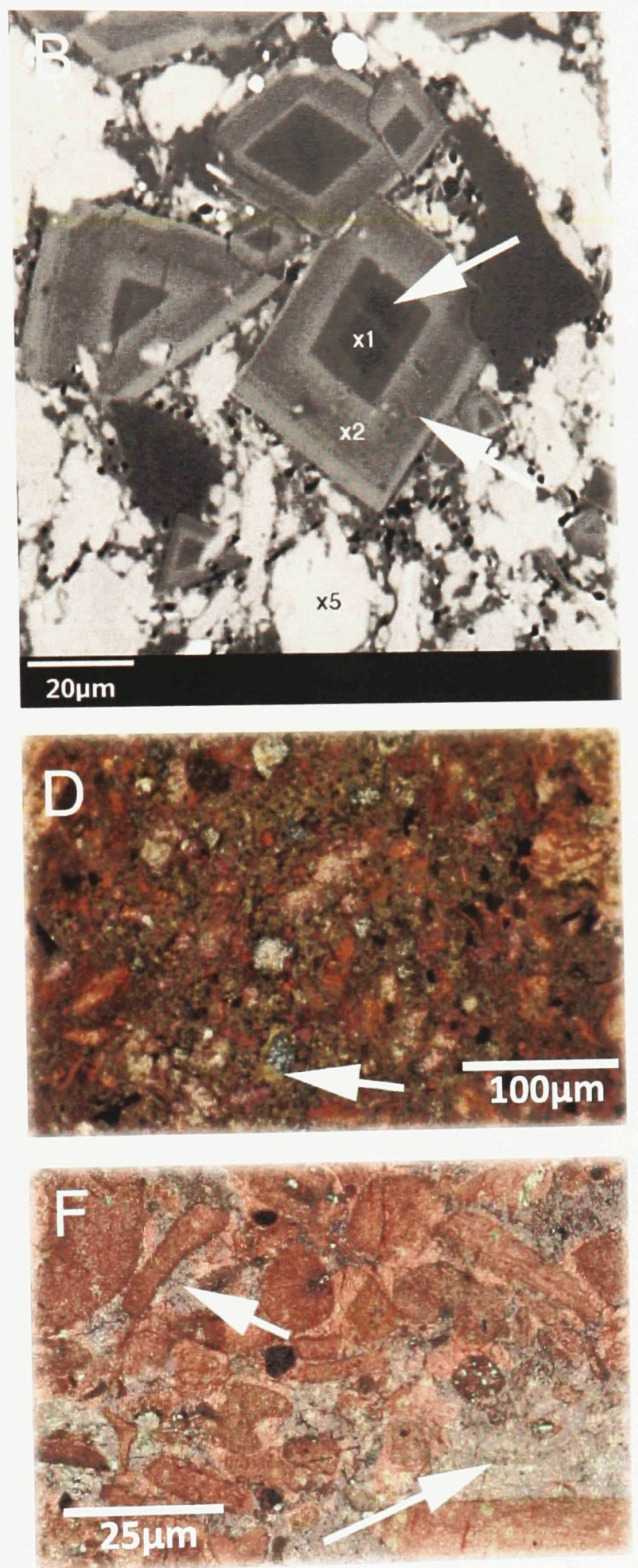


\section{Carbon and Oxygen Isotopes}

Samples of cement and dolomite were examined and are reported in Figure 24. It was difficult to separate Type II and Type III cement because of the fine-grained and spatially juxtaposed position of these cements. Thus, several values represent a "mixed" composition. The data are shown relative to marine brachiopod values for equivalent time period (Shields et al. 2003). Values of $\delta^{13} \mathrm{C}$ for both Type II and III cements range between $0.34 \%$ and $-0.63 \%$, and the values of $\delta^{18} \mathrm{O}$ range between $-5.76 \%$ and $-7.87 \%$ (Figure 24; Appendix IV). The field describes what appears to be a positive linear trend. This trend lies at more negative $\delta^{18} \mathrm{O}$ values than the marine skeletal field, whereas the $\delta^{13} \mathrm{C}$ values fall within the marine range.

In most carbonate platform systems, burial cements illustrate a negative shift in both $\delta^{13} \mathrm{C}$ and $\delta^{18} \mathrm{O}$ values relative to marine fields (Tucker and Wright 1990). This shift can be accounted for by either an increase in burial temperature or influx of meteoric-derived pore fluids that contain bicarbonate depleted in ${ }^{18} \mathrm{O}$.

It was not possible to separate the non-ferroan cores from the dolomite. Dolomite associated with Type III cement and burrows were sampled, and describe a relatively small field that lies within the range of the Type II and III calcite cement; that is, $\delta^{13} \mathrm{C}$ values range from $-0.13 \%$ to $-1.21 \%$, and $\delta^{18} \mathrm{O}$ values range from $-6.2 \%$ to $-7.2 \%$. The 
Page Facing 64

Figure 24. Carbon and oxygen isotope values of cement Type III, a mixture of cement Type II and III, Ordovician brachiopods (Shields et al. 2003) and dolomite. Shaded area represents shallow water marine dolomite values (Shields et al. 2003). 


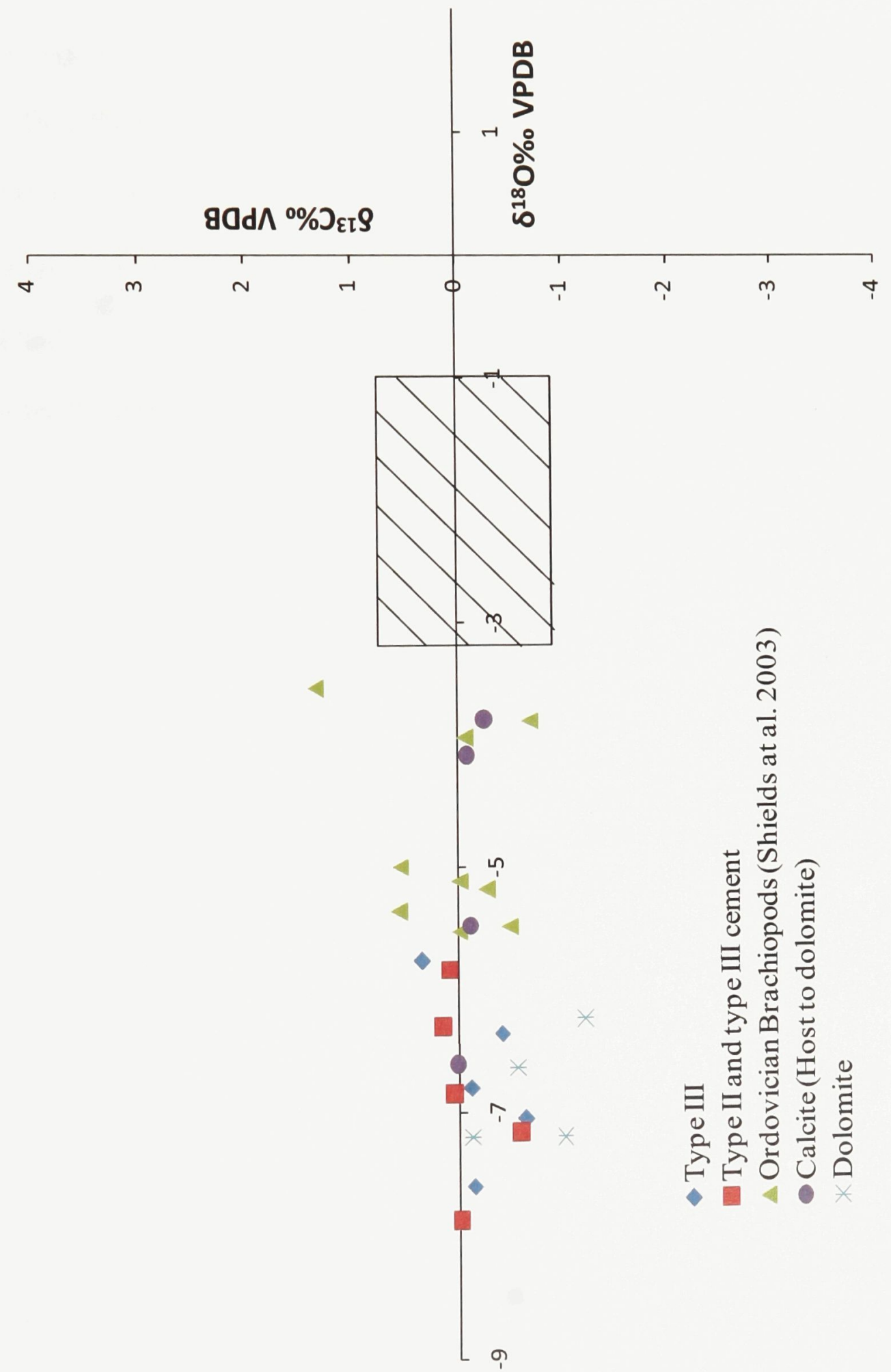


$\delta^{13} \mathrm{C}$ values overlap and are more negative than the marine calcite and diagenetic cement fields, whereas the $\delta^{18} \mathrm{O}$ values fall within the diagenetic cement field. There may be a negative trend defined by the dolomite field.

Shallow-water marine dolomite of contemporaneous age would have $\delta^{18} \mathrm{O}$ values $+2.6 \%$ than coexisting marine calcite if they had been both precipitated in isotopic equilibrium from the same solution at the same temperature (Vasconcelos et al. 2005). This field is shown in Figure 24, and it demonstrates that the dolomite from the Lindsay Formation is more depleted in ${ }^{18} \mathrm{O}$, requiring elevated temperature or a meteoric source of bicarbonate to account for the negative shift in $\delta^{18} \mathrm{O}$. 


\section{DISCUSSION}

\section{Regional stratigraphic history}

Using the carbonate ramp model by Burchette and Wright (1992), the carbonate dominated lithofacies of the Lindsay Formation was deposited in a mid-ramp setting. The siliciclastics lithofacies was deposited in an offshore basin. The carbonate facies of the Lindsay Formation are generally dominated by evidence for well reworked sand to gravel-bearing sediment and a reduced presence of carbonate mud which suggests some form of storm reworking below the fair weather wave base in the mid-ramp region and extensive bioturbation. There is no evidence of subaerial exposure during the formation's accumulation and this also supports a subtidal mid-ramp depositional setting.

The Lindsay Formation represents the final stage of Upper Ordovician carbonate platform development, represented by the Ottawa Group, within the local Taconic foreland basin. The stratigraphic succession records an overall increase in water depth, from peritidal to open storm dominated ramp facies (Salad Hersi and Dix 1999) as represented by the Verulam and Lindsay Formations. The foreland basin was developed in response to increased subsidence due to lithospheric flexuring along eastern Laurentia (now eastern North America) due to plate-boundary collision and closure of the Iapetan ocean basin (Rowley and Kidd 1981; Bradley and Kidd 1991). Diachronous east to west progression of subsidence was coincident with the progressive westward change from carbonate dominated to siliciclastic sedimentation followed by onlap of axially dispersed sediment within the foreland basin (Bradley and Kidd 1991; Lehmann et al. 1995). Onset 
of deposition of the Billings Formation represents shale deposition in a deep-water anoxic basin following the regional collapse of the carbonate platform (Sharma et al. 2003). The deep-basin shale of the Billings Formation buried the shallow-water carbonate ramp (Lindsay Formation).

The lower boundary of the Lindsay Formation in this study is equivalent to that reported by Williams (1991). Mapping has shown that the Nepean Point Member of the Lindsay Formation is underlain conformably by the Verulam Formation. From available sites, there appears to be a regionally uniform distribution of the Nepean Point Member, dominated by $\mathrm{C} 2$ and $\mathrm{C} 3$ facies in the Ottawa region, but $\mathrm{C} 2$ facies farther to the east. This fine to coarse-grained facies assemblage is equivalent to shaly skeletal carbonates in southern Quebec (Tetreauville Formation). This may indicate a progressive increase in fine-grained carbonates moving in a paleoseaward direction; that is, into deeper water.

One anomaly to this distribution is the apparent abrupt thickening of the Nepean Point Member in the Russell core compared to the Billings Bridge. This could be due to structural control and local differential subsidence. There needs to be drill core obtained from sites between these two localities in order to test this hypothesis.

The Eastview Member documents a substantial change in the stratigraphic arrangement and facies types; namely introduction of prominent siliciclastics. Previous work in Ohio (Holland and Patzkowsky 1996), along the New York Promontory (Fisher 1977), Quebec (Lavoie 1993), central Ontario (Dix et al. 2007), and in western Newfoundland (Knight et al. 1991), reveal an east-to-west diachronous collapse of the Upper Ordovician platform 
from the eastern margin of the North American craton into the its central core (Figure 25).

Previous workers have linked the final stage of collapse of the carbonate platform to the onset of Billings Formation deposition (e.g., Williams 1991). The Eastview Member is interpreted to record the early transition from relatively shallow-water ramp facies of a carbonate platform into the deep water shale succession of the Billings Formation.

The siliciclastic-carbonate stratigraphic fabric within the Eastview Member reveals that influx of siliciclastics, likely from the Taconic arc, was not continuous but subject to some rhythmic control creating the interbedded and internodular limestone with shale.

There is a gradual increase in shale beds and thinner, fewer more widely spaced limestone beds upsection from the Nepean Point Member to the Eastview Member. Thus, the influx of the terrigenous sediment gradually subdued carbonate production and eventually drowned the foreland carbonate platform. A sharp decline in carbonate content through to the Billings Formation is observed within the Eastview Member.

The rhythmic succession of interbedded siliciclastics and carbonates may indicate climatic, oceanographic, and-or sea-level cycles (Weedon 1985a, b; Brett et al. 2006) that influence abundance, preservation and diversity of fossils, production of carbonate, and influx of siliciclastics. Meter-scale, limestone-shale cycles are a consistent pattern of Phanerozoic offshore marine mixed facies (House 1985; Hallam 1986; Holland et al. 1997). The increasing dominance of shale content moving upsection is interpreted to indicate a more seaward, deeper, and overall lower energy setting. The changing 
Page Facing 69

Figure 25. Caradocian and Ashgillian strata of northeastern North America. Formational names included on the diagram. Hiatuses are represented by vertical lines (Modified from MacLachlan 1967; Liberty 1978; Sweet and Bergstrom 1976; Fisher 1979; Bergstrom and Mitchell 1986; Keith 1988; Holland 1989; Lehmann and Brett 1991; Lavoie 1992). 


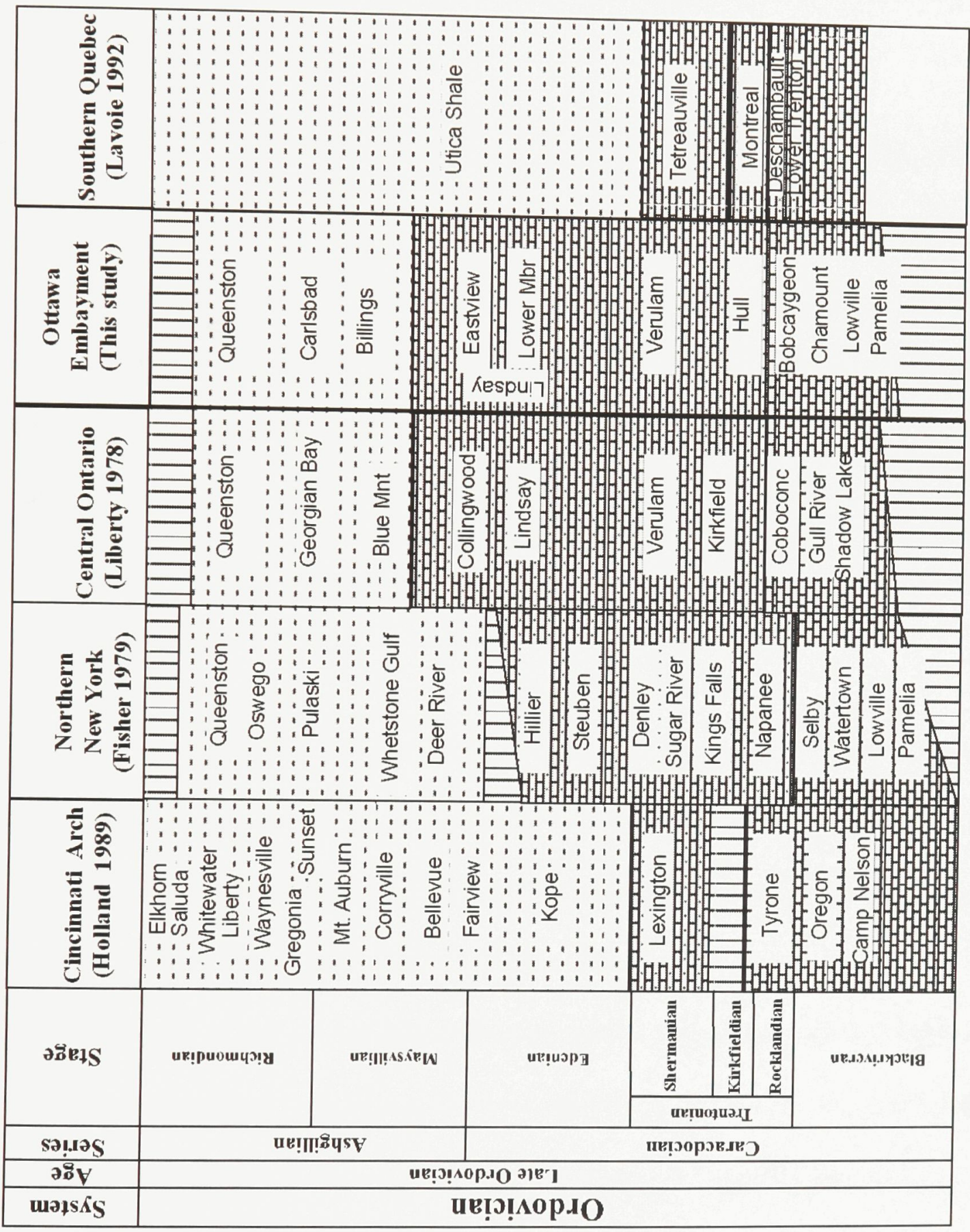


abundance of fauna may be due to a variety of controls: fluctuations in dysoxic to welloxygenated conditions; changes in sedimentation rate; influx of siliciclastic mud and sediment starvation combined with biological productivity, producing skeletal-rich deposits (Brett at al 2006).

In central Ontario, equivalent strata, the Collingwood Member, represents a similar transitional stage in the collapse of the local carbonate platform (Raymond 1914; Wilson 1946; Williams 1991). The Collingwood Member contains a similar stratigraphic arrangement and fossil content as the Eastview Member, with the exception of phosphate capping the stratigraphic interval (Brett et al. 2006). Phosphatic layers capping a stratigraphic interval often indicate little to no sediment accumulation. Its absence in eastern Ontario identifies significant differences in local basin development at the same time.

As with the stratigraphic anomaly associated with the Nepean Point Member, there is also a thickness anomaly connected to the Eastview Member. Between Billings Bridge and the Russell cores, a reversal of the thickness succession is found in comparison to the sense provided by the Nepean Point Member. If this is a structural control, then it requires reversal of the net subsidence history across the same fault that influenced the Nepean Point Member's change in thickness. However, it may be accommodated by a prominent disconformity although this is not obvious in core. Such an erosional surface could be linked to marked increase in subsidence and failure along a deep-water ramp margin. 
Local effects of minor topographic uplifts and depressions have produced subtle patterns of lateral facies change during foreland basin development in eastern North America, linked to far-field tectonism associated with the Taconic orogenesis (Ettensohn et al. 2002). Movement along the hypothesized fault between Billings Bridge and Russell core sites may be evidence for local structural control driven by distal plate-boundary tectonism.

\section{Paleoenvironmental considerations of the Lindsay Formation}

The lithofacies present in the Lindsay Formation suggest deposition in a shallow-water carbonate ramp environment. In eastern North America during the Late Ordovician, a change from warm-water tropical to cool-water temperate conditions is interpreted to have occurred as recorded by a change in sedimentary facies across the BlackriverianTrentonian boundary (e.g., Brookfield 1988; Lavoie 1995; Holland and Patzkowsky 1997; Pope and Read 1997; Lavoie and Asselin 1998; see Figure 25 for the Blackriverian-Trentonian boundary). The change corresponds to a major flooding event associated with regional tectonic drivers associated with development of the Taconic orogeny (Holland and Patzkowsky 1996). This supposedly led to local and regional upwelling of cool water, increased water turbidity, onset of local glaciation and increased nutrient influx (Brookfield 1988; Nelson 1988; Holland and Patzkowsky 1996).

Evidence of a tropical environment for the Blackriverian successions of eastern North America (Lavoie et al. 1998) is based on a relatively abundant chlorozoan grain assemblage, and a broad range of carbonate grains, including skeletal grains, peloids, 
ooids and intraclasts. Carbonate mud is usually abundant (Holland and Patzkowsky 1996).

In contrast, James (1997) provided a list of six criteria for the identification of temperate (cool-water) carbonate settings. In order, from highest to lowest reliability, they are listed as follows: 1) interbedding with glaciogenic deposits; 2) high paleolatitude; 3) occurrence of cool-water, abiotic phases, such as glendonite; 4) deposits entirely of heterozoan graintype associations, including the equivalent bryomol (bryozoans and mollusks; James 1997), foramol (foraminifers and mollusks; Lees and Buller 1972) and bryonoderm (bryozoans, echinoderms; Beauchamp 1994, Lavoie 1995; Brookfield 1988); 5) interbedding of chlorozoan and heterozoan grain type associations; and 6) geochemical data from bioclasts and cements that identify paleotemperature of the seawater. In the following, evidence of cool- and-or warm water attributes is examined.

The first three lines of evidence do not fit the attributes of the Lindsay Formation. There is no evidence of glaciogenic sediment; in the Late Ordovician, this part of ancient eastern North America was in the low latitudes $\left(20^{0} \mathrm{~S}\right)$ and was somewhat rotated clockwise from its present orientation (Scotese and Mckerrow 1991); and there is no evidence for abiotic formation of cool-water precipitates. Thus, any classification of the Lindsay Formation as warm- or cool-water in origin must be considered to be of low reliability based on the succession defined by James (1997). However, the following examines the last three on the list. 
Skeletal assemblage and texture. Facies analysis of the Nepean Point Member of the Lindsay Formation shows that carbonate and siliciclastics facies accumulated within marine, subtidal environments. There is no evidence for exposure surfaces, dissolution related to paleokarst, or paleosol development. Instead, the carbonate facies are overwhelmingly dominated by evidence for well reworked sand to gravel-bearing sediment, a reduced presence of carbonate mud, well stratified sediment indicative of strong wave or current activity, and extensive bioturbation.

The predominant lithofacies represented by the Nepean Point Member contains a rather limited diversity bryonoderm association; that is, there is a predominance of bryozoans and echinoderms without ooids, micrite and aggregate grains (Beauchamp 1994). Sediment textures are predominantly sand and gravel as also found in cool-water platforms (Holland and Patzkowsky 1996). Carbonate mud may be a result of the disintegration of large skeletal particles into their smallest crystallographic composition (Jones and Desrochers 1992). In contrast to the typical heterozoan facies, the Lindsay Formation contains abundant peloids in the Nepean Point Member. The peloids may arise from reworking of microbial overgrowths on skeletal grains. This encrusting material would have broken down to form circular peloids and eventually transported throughout the lithofacies of the Nepean Point Member.

Chlorophytic (dasycladacean) algae. Fragments of these algae are not common, but do occur within the Eastview Member of the Lindsay Formation. Typically, these grain types are notably absent from cool-water deposits, and their occurrence within interbedded strata signals change in water depth or rapid changes in climate. In the 
Lindsay Formation, there is no obvious restriction of the calcareous algae to specific beds. Their presence requires that there was, at least locally, warm water, somewhat hypersaline (Wray 1977).

The modern division of carbonate sediments into foramol and chlorozoan assemblages is mainly due to salinity and temperature only not on paleoclimatic conditions (Jones and Desrochers 1992). Isolated occurrences of dasycladacean green algae have been reported in the Cincinnatian (Dalvé 1948), therefore their occurrence in the Eastview Member may also be an isolated occurrence. Another possibility is that temperature had a role without supporting a temperate carbonate setting. The Eastview Member could have been at the temperature limit at which these algae can survive. Few species have been reported to live in warm temperate waters (Wray 1977).

Interestingly, isotopic $(\mathrm{C}, \mathrm{O})$ data from carbonate rocks (Hillier Formation) equivalent to the Lindsay Formation in New York State indicate that Ordovician seawater may have been saline and warm (Railsback et al. 1990). This may indicate that there was not a regional distribution of cool waters, but a mosaic of warm and cool depending on local basin conditions. For example, phosphatic material observed on hardgrounds in southern Quebec (Trenton Group) (Lavoie 1992), and phosphates capping the Collingwood Member in southern Ontario (Brett et al. 2006) identify elevated productivity relative to reduced sediment accumulation. The absence in eastern Ontario of equivalent stratigraphy suggests that this part of the foreland basin was somewhat different environmentally. It has been suggested, for example, that the modern foramol assemblage occur in tropical environments where annual minimum salinity is lowered by less 
evaporated temperate water extending into warmer tropical settings, thereby displacing tropical carbonates (Lees 1975).

The Lindsay Formation is not anomalous in having evidence of chlorozoan grain types associated with a predominant bryonoderm facies. In the older Hull Formation, also within the Trentonian succession, there is evidence of ooids, micrite, calcareous chlorophytes, intraclasts and colonial corals (Kiernan 1999). This work indicated that these grain types may have been predominant behind regional barrier shoals, within solar-heated lagoons. Finally, the Lindsay Formation may simply be part of the temporal transition back to tropical biofacies recorded elsewhere in the latest Ordovician (Holland and Patzkowsky 1996) and that this transition was locally interrupted by tectonically driven collapse of the platform.

\section{Character of Diagenesis}

The paragenetic sequence (Table 4) indicates that the post-depositional history of the Lindsay Formation evolved from a fully marine through to deep burial setting. There is no evidence of subaerial exposure during the formation's accumulation. Shallow-burial pore fluids were marine derived.

The production of the highly fragmented skeletal fabric of the Nepean Point Member reflects extensive marine diagenesis that includes bioturbation, likely predation by trilobites and orthocones, and wave or current reworking. Reduced rates of sediment accumulation allowed formation of microbial encrustation. Some skeletal grains show evidence of endolithic algal micritization, also evidence that sediment lay on the seafloor 
exposed to biotic influence (Bathurst 1975). This marine diagenesis may have predisposed the altered grains to enhanced breakage due to weakening of the original skeletal structure. The minor presence of micritic intraclasts (facies C5) may indicate that there were periods of lower energy, yet they identify likely seafloor cementation and reworking with re-establishment of higher energy conditions. However, there is no evidence for marine cement fabrics as sometimes found in some carbonate systems (James and Choquette 1990a; Tucker and Wright 1990)

Onset of shallow-burial diagenesis did not produce a homogenous diagenetic fabric. Instead, mechanical compaction was impeded by early burial overgrowth cement, with only local areas lacking this cementation. The effect was to form, in the shallow-burial setting, a permeable rock. The change in cement type from iron-poor overgrowth to ironbearing void-fill (blocky) calcite is similar to burial diagenetic patterns documented from other platform carbonate systems (James and Choquette 1990c; Tucker and Wright 1990; Scholle and Ulmer- Scholle 1978). The once relatively abundant pore spaces in the early cemented subsurface were extensively filled by, first, pink, then purple cement (Figures 23E \& F). The Lindsay cement stratigraphy from iron-poor to ferroan calcite signals either an introduction of iron or dramatic loss of oxygen. If the latter, then the iron-poor cements must have formed fairly close to the seafloor, with marine fluids accessing the subsurface through the permeable sediment. The isotopic evidence supports this by indicating a progressive decrease in oxygen isotope composition through the Type II and III progression. 
If pore-water were marine-derived, an estimate of the paleotemperature and burial depth can be defined in a very general manner (Figure 26). Typical day surface water temperatures in tropical settings range between $23^{\circ} \mathrm{C}$ and $27^{\circ} \mathrm{C}$ (Azmy et al. 1998).

Shields et al. (2003) proposed that $\delta^{18} \mathrm{O}$ values of seawater were likely $-3 \%$ to $-4 \%$ based on the data derived from marine brachiopods (Figure 26). Assuming that no isotopic change occurred to the marine-derived pore fluids within the shallow-burial environment the pink (Type II) and purple (Type III) cements identify a possible temperature of $25^{\circ} \mathrm{C}$ to $35^{\circ} \mathrm{C}$. Given the variable daily temperatures one might find in tropical settings (Tucker and Wright 1990), this supports a very near surface formation. Assuming a geothermal gradient of $20-25^{\circ} \mathrm{C} / \mathrm{km}$, the added $\left(8^{\circ} \mathrm{C}\right)$ to the estimated daily temperature of Azmy et al. (1998) corresponds to a burial depth of 300-400 m. Textural information demonstrates that the pink calcite cement (Type II) predates burial stylolites, which can form at depths as shallow as $300 \mathrm{~m}$ (James and Choquette 1990c). Again, this supports a shallow-burial origin for these cements.

Dolomite occurs in association with burrows, along stylolites and as crystalline mosaics scattered within the limestone. Dolomite may form in limestones when significant magnesium is available and released during pressure solution (Folk 1974). This might occur through alteration of high-Mg skeletal material (like crinoids), or from $\mathrm{Mg}$ derived from seawater. It has been suggested that burrows act as conduits for dolomitizing fluids in early and well-cemented limestones during burial diagenesis (Morrow 1978). Their formation occurs as a by-product of the breakdown of organic material in burrows that 
Page Facing 78

Figure 26. $\delta^{18} \mathrm{O}$ calcite versus temperature (After Land 1983). 


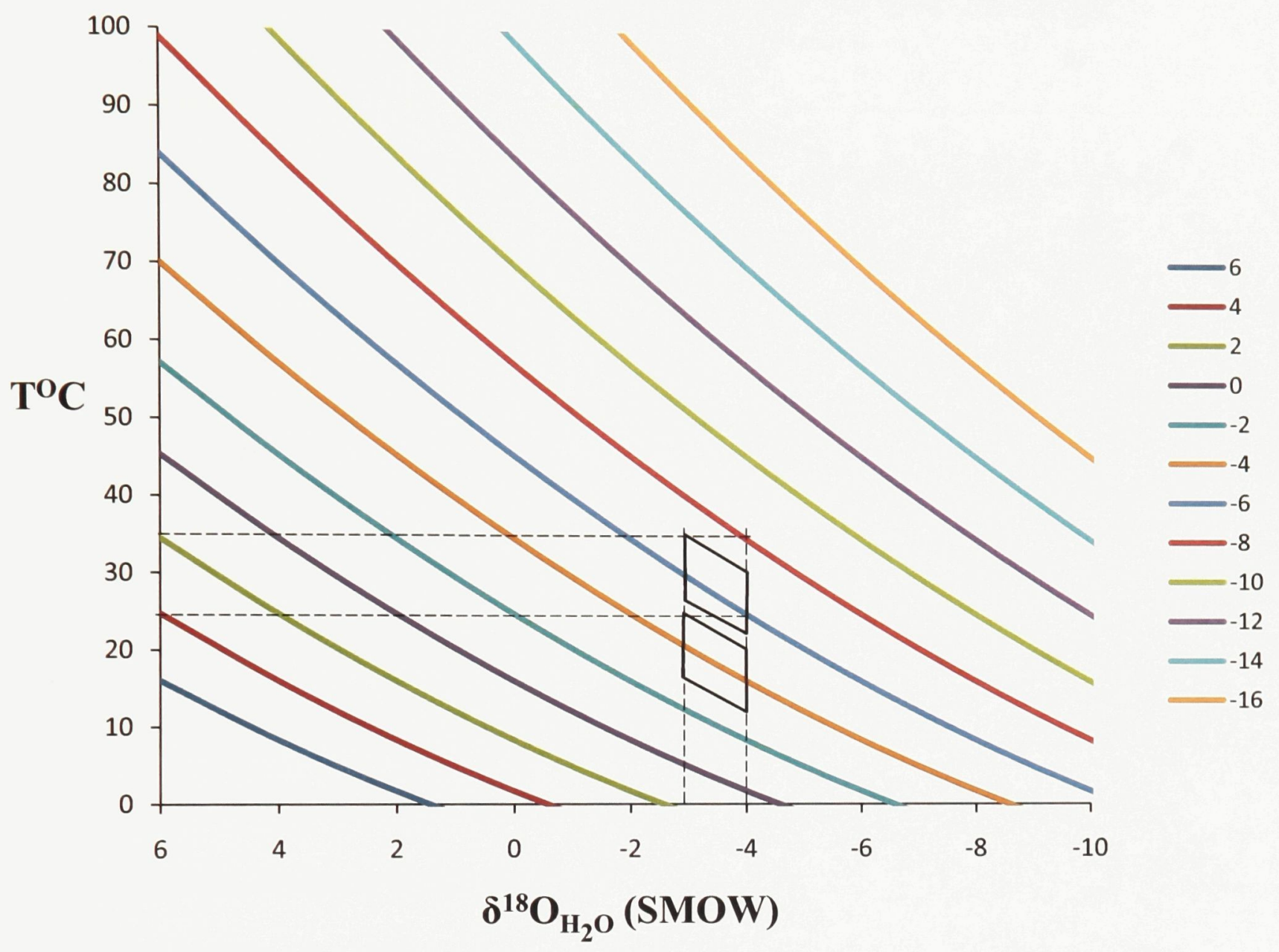


will locally increase the porosity and permeability around the burrow fabrics. Dolomite along stylolites record release of $\mathrm{Mg}$ from chemical compaction of the bounding limestone (Bathurst 1975).

The possibility of burrow-fill dolomite being of shallow to deep-burial origin can be tested using the same approach as for calcite. Ideal marine dolomite, based on the parameters set out by Shields et al. (2003), should have a composition of about $-2 \%$ to 4\%o (Figure 27). Incorporating the Lindsay Formation dolomite, the estimated formation temperature is $\sim 50^{\circ} \mathrm{C}$ (Figure 27). Assuming a geothermal gradient range and seawater temperature as above, the estimated burial depth is $\sim 1 \mathrm{~km}$. This seems unlikely to fit the normal model for burrow-fill dolomite, and the Lindsay Formation data offers two qualifications that need to be considered. First, the dolomite is spatially associated with clays. Release of $\mathrm{Mg}$ due to clay dewatering often begins by $1 \mathrm{~km}$ burial depth (Burst 1976). Likewise, evidence for the formation of some dolomite along stylolites indicates a minimum burial depth of $300 \mathrm{~m}$ (James and Choquette 1990c). Second, nearly all the dolomite examined is zoned, with a complicated paragenetic history linked to Fe-poor (zoned) cores and microzoned Fe-enriched rims that are, otherwise, the most prominent dolomite phase in all the Lindsay Formation. Only the dolomite related to stylolite formation appears to be different from this trend, being non-ferroan. This identifies a complex multistage production. The simplest is that the cores are of shallow-burial origin, overgrown with deeper burial dolomite that was pervasive throughout the formation. Evidence for some dissolution within the cores supports an early unstable 
Page Facing 80

Figure 27. $\delta^{18} \mathrm{O}$ calcite versus temperature for various $\delta^{18} \mathrm{O}$ values. After Land 1983. 


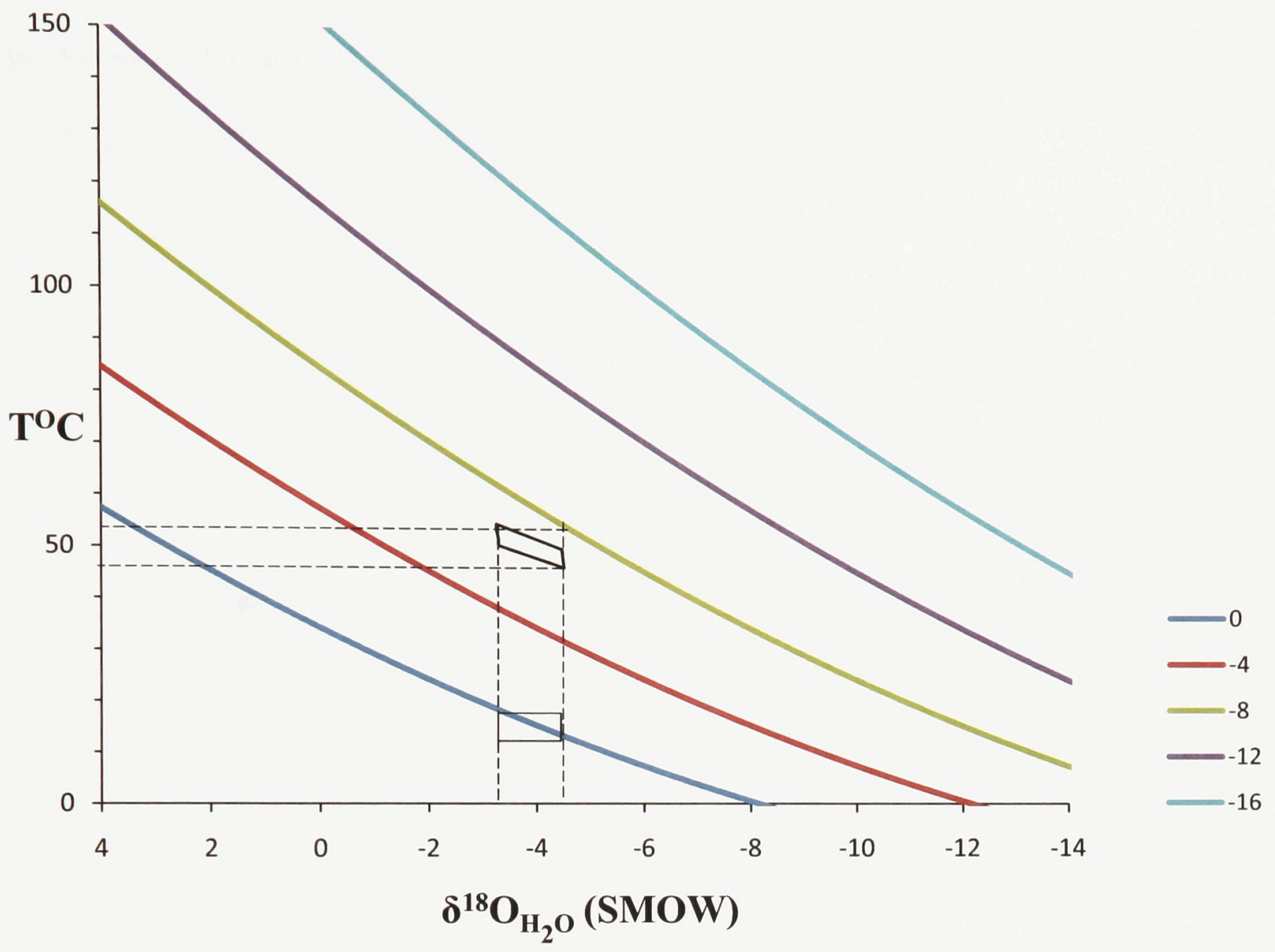


phase. As the Fe-enriched rims are thicker than the core, the isotope composition reflects the deeper burial phase, not the cores. 


\section{CONCLUSIONS}

1. The Upper Ordovician Ottawa Group represents the principal carbonate platform succession within the local Taconic foreland basin established along eastern Laurentia. The Lindsay Formation forms the final stage (i.e. uppermost unit of the Ottawa Group) of relatively shallow-water shelf deposition of Edenian to Maysvillian age, $\sim 453-452 \mathrm{Ma}$. Incorporation of outcrop and core sections shows that it conformably overlies the Verulam Formation. Incorporation of core and outcrop sections reveals a prominent thickness $(\sim 4 \mathrm{~m})$ increase in the Nepean Point Member moving SE from Ottawa to the Russell, Ontario region. Within the Eastview Member, the thickness increases $(4 \mathrm{~m})$ between these two areas in the reverse direction. These differences may indicate local differential subsidence that influenced the Nepean Point Member development. In the case of the Eastview Member, it may reveal a prominent erosional truncation downcutting to the SE despite no indication of a disconformity at the formation boundary with the overlying Billings Formation.

2. The Lindsay Formation is divided into (1) a "Nepean Point Member" and (2) the overlying Eastview Member. The Nepean Point Member is composed of nodular, highly bioturbated, fine to coarse grained, thin to thick, highly fossiliferous (crinoid bearing) limestone beds interbedded with very thin beds to laminae of calcareous shale. The upper (Eastview) Member, consists of rhythmically interbedded lime mudstone to skeletal mudstone and dark brown to black organic- 
rich calcareous to non-calcareous shale, within which are skeletal rudstones (skeletal hash).

3. The extent of bioturbation in the Nepean Point Member of the Lindsay Formation in comparison with the underlying finely-stratified storm dominated facies of the Verulam Formation demonstrates a dramatic yet conformable change in shelf conditions during the waning stages of platform development. The Lindsay Formation defines a relatively open, well oxygenated shelf and it is overlain by euxinic, deep water sediments of the Billings Formation.

4. The Eastview Member's pronounced interstratification of shale and carbonate records likely alternation of oceanographic and/or sea level changes that influenced depositional conditions. However, the Eastview defines an apparent transition from the open shallow shelf of the Nepean Point Member to the deepwater conditions of the overlying Billing Formation. A similar history is associated with the Collingwood Member of the Lindsay Formation in central and southwestern Ontario, with the exception that the former basin area records a prominent final phosphatization episode prior to burial by deep-water shale.

5. The Lindsay Formation is represented by a wide range of lithofacies and they include five carbonate dominated facies (C1-C5) which are indicative of deposition in a shallow ramp environment and three siliciclastic dominated facies (S1-S3) which are indicative of a deeper shelf environment. 
6. The grain types present in the Lindsay Formation are typical of temperate-like carbonate depositional settings with an apparent bryonoderm dominance, which includes the prevalence of bryozoans and echinoderms without ooids, micrite and aggregate grains. However, fragments of the calcareous dasycladacean green algae and peloids are observed within the carbonate lithofacies of the Eastview Member, suggesting that there may have been some local warm, hypersaline conditions. There is no other supporting evidence for a temperate carbonate setting than the bryonoderm grain type association. Therefore factors, such as local shoal development or salinity may have played an important role in the distribution of grain types and water temperature.

7. Paragenetic succession of the Lindsay Formation indicates a successive history of marine through to burial environmental alteration, with later horizontal compression. Marine signatures include burrows, micritized skeletal material and microbial encrustation. Burial alteration is evidenced by mechanical compaction, non-ferroan calcite overgrowth cement, and both non-ferroan and ferroan void-fill calcite cement occupying remaining porosity including sub-vertical fracture porosity. Burial (horizontal) stylolites cross-cut the fracture fill cement indicating that void-fill cementation likely predates $\sim 300 \mathrm{~m}$ burial depth based on modeled chemical compaction of carbonate rocks. Sub-vertical stylolites, indicative of lateral compression, cross-cut all of the above and indicate likely strike-slip faulting at some younger age. The above history is supported from $\mathrm{C}$ - and $\mathrm{O}$ isotope analysis of the void-fill cements $\left(\delta^{13} \mathrm{C}\right.$ from $0.34 \%$ to $-0.63 \%$ and $\delta^{18} \mathrm{O}$ 
from $-5.76 \%$ to $-7.87 \%$ ) shows formation in the near surface at slightly elevated temperatures.

8. Dolomite occurs in burrows, and is also associated with ferroan calcite cement and found along stylolites. The typical paragenetic succession contains an Fepoor, but CL-zoned (dark to bright) core overgrown by an Fe-enriched microzoned rim, the latter making up the majority of any dolomite crystal. Many of the dolomites are entirely microzoned and ferroan in composition. The cores show evidence of dissolution of an unstable phase, yet filled by Fe-poor dolomite fill prior to the overgrowth ferroan dolomite. $\mathrm{C}$ - and $\mathrm{O}$-isotope analysis of the dolomite provides values $\left(\delta^{13} \mathrm{C}\right.$ ranges from $-0.13 \%$ to $-1.21 \%$ and $\delta^{18} \mathrm{O}$ ranges from $-6.2 \%$ to $-7.2 \%$ ) that suggest deep $(\sim 1 \mathrm{~km})$ burial formation. However, the isotopic signature is likely swamped by the dolomite-rim composition, and not a reflection of the complicated paragenetic succession defined petrographically. 


\section{REFERENCES}

Azmy, K., Veizer, J., Bassett, M.G., and Copper, P. 1998. Oxygen and carbon isotopic compositions of Silurian brachiopods: Implications for coeval seawater and glaciations. Geological Society of America Bulletin, 110: 1499-1512.

Baldwin, B. 1971. Ways of deciphering compacted sediments. Journal of Sedimentary Petrology, 41: 293-301.

Barnes, C.R., Norford, B.S., and Skevington, D. 1981. The Ordovician System in Canada. International Union of Geological Sciences, Publication No. 8.

Bathurst, R.C.G. 1975. Carbonate Sediments and their Diagenesis. Elsevier, Amsterdam, pp. 658.

Beadle, S.C. 1988. Dasyclads, cyclocrinitids and receptaculitids: Comparative morphology and paleoecology. Lethaia, 21: 1-21.

Beauchamp, B. 1994. Permian climatic cooling in the Canadian arctic. In Pangea: Paleoclimate, Tectonics and Sedimentation during Accretion, Zenith and Breakup of a Supercontinent. Edited by G.V. Klein. Geological Society of America, Special Paper, 288: $229-246$.

Bergstrom, S.M., and Mitchell, C.E., 1986. The graptolite correlation of the North America Upper Ordovician standard: Lethaia, 19: 247-266. 
Bradley, D.C. and Kidd, W.S.F.1991. Flexural extension of the upper continental crust in collisional fore deeps: Geological Society of America Bulletin, 103: 1416-1438.

Brett, E.B., Allison, P.A., Tsujita, C.J., Soldani, D., and Moffat, H.A. 2006. Sedimentology, taphonomy, and Paleoecology of Meter-Scale Cycles from the Upper Ordovician of Ontario. Society of Sedimentary Geology. PALAIOS, 21: 530-547.

Brett, C.E., and Baird, G.C. 1986. Comparative taphonomy: a key to paleoenvironmental interpretation based on fossil preservation. PALAOIS, 1: 207-227.

Brookfield, M.E. 1988. A mid-Ordovician temperate carbonate shelf- the Black River and Trenton Limestone Groups of southern Ontario, Canada. Sedimentary Geology, 60: 137154.

Burchette, T.P., and Wright, V.P. 1992. Carbonate ramp depositional systems: Sedimentary Geology, 79: 3-57.

Burst, J.F. 1976. Argillaceous sediment dewatering. Annual Reviews of Earth and Planetary Science, 4: 293-318.

Choquette, P.W., and James, N.P. 1987. Diagenesis in Limestone-3. The deep burial environment: Geoscience Canada, 14: 3-35.

Clark, T.H. 1972a. Montreal Area; Ministere des Richesses Naturelles du Quebec. Geological Report, 152: 244. 
Clark, T.H. 1972b. Stratigraphy and Structure of the St. Lawrence Lowland of Quebec; $24^{\text {th }}$ International Geological Congress, Field Excursion C52, Guidebook, pp. 82.

Cushing, H.P., Fairchild, H.L., Ruedemann, R., and Smyth, C.H. 1910. Geology of the Thousand Islands Region; New York State Museum, Bulletin, 145: 194.

Dalvé, E. 1948. The fossil fauna of the Ordovician in the Cincinnati region: Cincinnati, Ohio, University Museum, Department of Geology and Geography, 56.

Derry, Michner, Booth, Wahl and Ontario Geological Survey 1989. Limestone industries of Ontario, Volume II: limestone industries and resources of eastern and northern Ontario. Ontario Ministry of Natural Resources, Land Management Branch.

Dickson, J.A.D. 1966. Carbonate identification and genesis as revealed by staining. Journal of Sedimentary Petrology, 36: 491-505.

Dix, G.R., and A1 Rodhan. Z. 2006. A new geological framework for the Middle Ordovician Carillion Formation (uppermost Beekmantown Group, Ottawa Embayment): onset of Taconic foreland deposition and tectonism within the Laurentian platform interior. Canadian Journal of Earth Sciences, 43: 1367-1387.

Dix, G.R., Coniglio, M., Riva, J.F.V., and Achab, A., 2007.The Upper Ordovician Dawson Point Formation (Timiskaming outlier, Ontario); new insights into RichmondianHirnantian paleogeography within the central Canadian craton. Canadian Journal of Earth Sciences, 44: 1313-1331. 
Dix, G.R and Robinson, W.R. 2003. The geochemical record of hydrothermal mineralization and tectonism inboard of the Appalachian Orogen: the Ottawa Embayment. Chemical Geology, 197: 29-53.

Dunham, R.J. 1962. Classification of carbonate rocks according to depositional texture: American Association of Petroleum Geologists Memoir, 1: 108-121.

Ettensohn, F.R., Hohman, J. C., Kulp, M. A., and Rast, N. 2002. Evidence and implications of possible far-field responses to the Taconian Orogeny: Middle-Late Ordovician Lexington Platform and Sebree Trough, east-central United States. Southeastern Geology, 41: 1-36.

Fisher, D.M. 1977. Correlation of the Hadrynian, Cambrian and Ordovician rocks of New York State. New York State Museum and Science Service, Map and Chart Series 25, p 75.

Fisher, D.W. 1979. Folding in the foreland, Middle Ordovician Dolgeville facies, Mohawk Valley, New York, Geology 7: 455-459.

Flügel, E. 2004. Microfacies of carbonate rocks. Analysis, Interpretation and Applications. Springer Berlin Heidelberg New York, pp. 976.

Foerste, A.F. 1924. Upper Ordovician Faunas of Ontario and Quebec. Geological Survey of Canada, Memoir 138, pp. 255.

Folk, R.L. 1974. Natural history of crystalline calcium carbonate: effect of magnesium content and salinity: Journal of Sedimentary Petrology, 44: 40-53. 
Frey, R.W., and Pemberton, S.G. 1984. Trace fossil facies models. In Facies models: St. John's, Newfoundland. Edited by R.G Walker. Geoscience Canada, pp. 189-207.

Fritz, M.A. 1957. Bryozoa (Mainly Trepostomata) from the Ottawa Formation (Middle Ordovician) of the Ottawa- St. Lawrence Lowland; Geological Survey of Canada, Bulletin 42, pp. 75.

Hallam, A. 1986. Origin of minor limestone-shale cycles: Climatically induced or diagenetic: Geology, 14: 609-612.

Hiscott, R.N. 1984. Ophiolite source rocks for Taconic age flysch: trace element evidence: Geological Society of America Bulletin, 95: 1261-1267.

Holland, S. 1989. Sequence-based correlation: Sorting through the complicated stratigraphy of the eastern United States: Geological Society of America Abstracts with Programs, 21, no. 6: 80 .

Holland, S.M., Miller, A.L., Dattilo, B.F., Meyer, D L., and Diekmeyer, S.L. 1997. Cycle anatomy and variability in the storm-dominated type Cincinnatian (Upper Ordovician): Coming to grips with cycle delineation and genesis: Journal of Geology, 105: 135-152.

Holland, S.M., and Patzkowsky, M.E. 1996. Sequence Stratigraphy and long-term paleoceanographic change in the Middle and Upper Ordovician of the eastern United States. I: Paleozoic Sequence Stratigraphy: Views from the North American Craton. Edited by Witzke, B.J., Ludvigsen, G.A., and Day, J.E. Special Paper-Geological Society of America, 306: 17-130. 
Holland, S.M. and Patzkowsky, M.E. 1997. Distal orogenic effects on peripheral bulge sedimentation: Middle and Upper Ordovician of the Nashville Dome. Journal of Sedimentary Research, 67: 250-263.

Holland, S.M., and Patzkowsky, M.E. 1998. Sequence stratigraphy and relative sea level history of the Middle and Upper Ordovician of the Nashville Dome, Tennessee. Journal of Sedimentary Research, 68: 684-699.

House, M. R. 1985. A new approach to an absolute timescale from measurements of orbital cycles and sedimentary microrhythm: Nature, 315: 721-725.

Immenhauser, A., Holmden, C., and Patterson, W. P. 2003. Interpreting the Carbon-Isotope record of ancient shallow epeiric seas: Lessons from the recent. Geological Association of Canada Special Paper, 48: 137-174.

James, N. P. 1997. The cool-water carbonate depositional realm. In Cool-water Carbonates. Edited by N.P. James and J. Clarke. Special Publication, Society for Sedimentology Geology, 56: 1-20.

James, N.P., and Choquette, P.W. 1990a. Limestones - the sea-floor diagenetic environment. In Diagenesis. Edited by I.A. MCIlerth and D.W. Morrow. Geoscience Canada Reprint Series No. 4, pp. 13-34.

James, N.P., and Choquette, P.W. 1990b. Limestones - the meteoric diagenetic environment. In Diagenesis. Edited by I.A. MCIlerth and D.W. Morrow. Geoscience Canada Reprint Series No. 4, pp. 35-75. 
James, N.P., and Choquette, P.W. 1990c. Limestones- The Burial Diagenetic Environment. In Diagenesis. Edited by I.A. MCIlerth and D.W. Morrow. Geoscience Canada Reprint Series No. 4, pp. 75-112.

Jones, B. 2007. Inside-out dolomite: Journal of Sedimentary Research, 77: 539-551.

Jones, B., and Desrochers, A. 1992. Shallow platform carbonates. In Facies Models: response to sea-level change. Edited by R.G. Walker and N.P. James. Geoscience Canada Reprint Series, Geological Association of Canada, pp. 277-302.

Kay, G.M. 1937.Stratigraphy of the Trento Group. Geological Society of American Bulletin, 48: $223-302$.

Kay, G.M. 1942. The Ottawa-Bonnechere graben- Lake Ontario homocline. Geological Society of American Bulletin, 53: 585-646.

Kay, G.M. 1968. Ordovician Formations in Northwestern New York. Naturaliste Canadien, 95: 1373-1378.

Keith, B. D. 1988. Regional facies of the Upper Ordovician series of eastern North American, In The Trenton Group (Upper Ordovician Series) of eastern North America. Edited by Keith, B. D., ed., American Association of Petroleum Geologists, Studies in Geology, 29: 113-134.

Kiernan, J.P. 1999. Lithostratigraphy, sedimentology and diagenesis of the Upper Ordovician Hull beds and Verulam Formation, Upper Ottawa Group, eastern Ontario. M.Sc thesis, Carleton University, Ottawa, Ontario, pp. 262. 
Knight, I., James, N.P., and Lane, T.E. 1991. The Ordovician St. George Unconformity, northern Appalachians: The relationship of plate convergence at the St. Lawrence Promontory to the Sauk/Tippecanoe sequence boundary. Bulletin of Geological Society of America, 103: 1200-1225.

Kumarapeli, P.S. 1985. Vestiges of Iapetan rifting in the craton west of the northern Appalachians: Geoscience Canada, 12: 54-59.

Kumarapeli, P.S., and Saull, V.A. 1966. The St. Lawrence valley system: a North American equivalent of the East African rift valley system. Canadian Journal of Earth Sciences, 3: 639-658.

Land, L.S. 1983. The application of stable isotopes to studies of the origin of dolomite and to problems of diagenesis of clastic sediments. In: Stable Isotopes in Sedimentary Geology. Edited by Arthur, M.A. Society of Economic Paleontologists and Mineralogists, Short Course, 10 pp. 4-1 to 4-22.

Lavoie, D. 1992. The Middle Ordovician (Caradocean) Deschambault Formation, St. Lawrence Lowlands, southern Quebec: a shallow water carbonate ramp on a drowning platform. Current Research Part. D; Geological Survey of Canada Paper 92-1D, 223-234.

Lavoie, D. 1993. Lithostratigraphy and paleoenvironmental evolution of the Upper Ordovician Trenton Group, southern Quebec; in Current Research, Part D; Geological Survey of Canada, Paper 93-1D, pp. 161-172. 
Lavoie, D. 1995. A Late Ordovician high-energy temperate-water carbonate ramp, southern Quebec, Canada: implications for Late Ordovician oceanography. Sedimentology, 42: 95 116.

Lavoie, D., and Asselin, E. 1998. Upper Ordovician facies in the Lac Saint-Jean outlier, Quebec (eastern Canada): paleoenvironmental significance for Late Ordovician oceanography. Sedimentology, 45: 817-832.

Lavoie, D., Ndzangou, O.S. and Bourque, P.A. 1998. The Black River - Trenton transition near Quebec City: a case for Ordovician global change? Geological Association of Canada - Minerological Association of Canada Joint Annual Meeting, Quebec 1998, Field Trip A8 Guidebook, pp. 58.

Lee, M.R. and Harwood, G.M. 1989. Dolomite calcitization and cement zonation related to uplift of the Raisby Formation (Zechstein carbonate), northeast England. Sedimentology Geology, 65: 285-305.

Lees, A. 1975. Possible influences of salinity and temperature on modern shelf carbonate sedimentation. Marine Geology, 19: 159-198.

Lees, A., and Buller, A.T. 1972. Modern temperate water and warm water shelf carbonates contrasted. Marine Geology, 13: 1767-1773.

Lehmann, D., and Brett, C. 1991. Tectonic and eustatic influences upon the sedimentary environments of the Upper Ordovician strata of New York and Ontario: Geological Society of America Abstracts with Programs, v. 23, no. 2, p. 29. 
Lehmann, D., Brett, C. E., Cole, R., and Baird, G. 1995. Distal sedimentation in a peripheral foreland basin: Ordovician black shales and associated flysch of the western Taconic foreland, New York State and Ontario. Geological Society of America Bulletin, 107: 708-724.

Liberty, B.A. 1978. Ordovician nomenclature of Manitoulin Island. In Geology of the Manitoulin Area including the road log to the Michigan Basin. Edited by Sanford, J.T., and Mosher, R.E. Geological Society Field Trip. Michigan Basin Geological Society, Special Paper, 3: 43-45.

Liberty, B.A. 1967. Ordovician stratigraphy of southern Ontario: the Ottawa Valley Problem. Geological Association of Canada - Mineralogical Association of Canada Joint Annual Meeting, Ottawa '67, Abstracts of Papers, pp. 49-50.

Liberty, B.A. 1969. Paleozoic geology of the Lake Simcoe area, Ontario. Geological Survey of Canada Memoir, 355: 201.

Logan, Sir William. E. 1863. Geology of Canada, Geological Survey of Canada, Report of Progress from its commencement to 1863 , pp. 983.

Maclachlan, D.B. 1967. Structure and stratigraphy of limestones and dolomites of Dauphin County, Pennsylvania Topographic and Geologic Survey, General Geology Report G44. pp. 168.

Mehrtens, C. J. 1988b. Comparison of foreland basin sequences: the Trenton Group in southern Quebec and central New York. In The Trenton Group (Upper Ordovician 
Series) of Eastern North America. Edited by Keith, B.D. American Association of Petroleum Geologists Studies in Geology, 29: 139-157.

Mehrtens, C.J.1988a. Bioclastic turbidites in the Trenton Limestone: Significance and criteria for recognition. In The Trenton Group (Upper Ordovician Series) of Eastern North American. Edited by Keith, B.D. American Association of Petroleum Geologists Studies in Geology, 29: 87-112.

Mereu, R.F., Wang, D., Kuhn, O., Forsyth, D.A., Green, A.G., Morel, P., Buchbinder, G.G.R., Crossley, D., Schwarz, E., Duberger, R., Brooks, C., and Clowers, R. 1986. The 1982 COCRUST seismic experiment across the Ottawa - Bonnechere graben and Grenville Front in Ontario and Quebec. Geophysical Journal Of the Royal Astronomical Society, 84: 491-514.

Morrow, D.W. 1978. Dolomitization of lower Paleozoic burrow-fillings. Journal of Sedimentary Petrology, 48: 295-306.

Murray, A. 1952. Report on the Geology of the Region between the Ottawa, St. Lawrence, and Rideau Rivers; Geological Survey of Canada, Report of Progress. 1851-52, pp. 5791.

Nelson, C.S. 1988. An introduction perspective on non-tropical carbonates. Sedimentary Geology, 60: 3-12.

Patterson, W.P. and Walter, L.M. 1994. Syndepositional diagenesis of modern platform carbonates: Evidence from isotopic and minor element data: Geology, 22: 127-130. 
Pope, M.C., and Read, J.F. 1997. High-resolution stratigraphy of the Lexington Limestone (Late Middle Ordovician), Kentucky, U.S.A. A cool-water carbonate-clastic ramp in a tectonically- active foreland basin. In Cool-water carbonates. Edited by N.P. James and J. A. D. Clarke. SEPM (Society for Sedimentary Geology), Special Publication, 56: 411430.

Railsback, L.B., Ackerly, S.C., Anderson, T.F., and Cisne, J.L. 1990. Paleontological and isotope evidence for warm saline deep waters in Ordovician oceans: Nature, 343: 156159.

Raymond, P.E. 1912. Ordovician of the Ottawa Valley. Geological Survey of Canada Summary Report for 1911, pp 348-349.

Raymond, P.E. 1914. The Trenton Group in Ontario and Quebec. Geological Survey of Canada Summary Report for 1912, pp. 348-349.

Raymond, P.E. 1921. A contribution to the description of the Fauna of the Trenton Group; Geological Survey of Canada, Museum Bulletin, 31: 64.

Rowley, D.B., and Kidd, W.S.F. 1981. Stratigraphic relationships and detrital composition of the Middle Ordovician flysch of western New England: Implications for the tectonic evolution of the Taconic orogeny: Journal of Geology, 89: 199-218.

Rudwick, M.J.S. 1970. Living and fossil brachiopods: London, England, Hutchinson University Library, pp.199. 
Russell, D.J., and Telford, P.G. 1983. Revisions to the stratigraphy of the Upper Ordovician Collingwood beds of Ontario - a potential oil shale: Canadian Journal of Earth Sciences, 20: $1780-1790$.

Salad Hersi, O., and Dix, G.R. 1999.Blackriveran (lower Mohawkian, Upper Ordovician) lithostratigraphy, rhythmicity, and paleogeography, Ottawa Embayment, eastern Ontario, Canada. Canadian Journal of Earth Sciences, 36: 2033-2050.

Sanford, B.V. 1993. St. Lawerence Platform - introduction. In Sedimentary Cover of the Craton in Canada. Edited by D.F. Stott and J.D. Aitken, J.D. Geological Survey of Canada. No. 5, pp. 709-722.

Scholle, P.A. and Ulmer-Scholle, D.A. 2003. A Color Guide to the Petrography of Carbonate Rocks: Grains, textures, porosity and diagenesis. AAPG Memoir 77. pp. 474.

Scoffin, T. P. 1987. An introduction to carbonate sediments and rocks. Blackie and Sons Limited. pp. 274.

Scotese, C.R., and McKerrow, W.S. 1991. Ordovician plate tectonic reconstructions. In Advances in Ordovician Geology. Edited by C.R. Barnes and S.H. Williams. Geological Survey of Canada, paper 90-09, pp. 272-282.

Sharma, S., Dix, G.R, and Riva, J.F.V. 2003. Late Ordovician platform foundering, its paleoceanography and burial, as preserved in separate basins, southern Ontario: Canadian Journal of Earth Sciences, 40: 135-148. 
Shields, G.A., Carden, G.A.F., Veizer, J., Meidla, T., Rong, J., and Li, R. 2003. Sr, C, and O isotope geochemistry of Ordovician brachiopods: A major isotopic event around the Middle-Late Ordovician transition. Geochimica et Cosmochinica Acta, vol. 67, no 11, pp 2005-2025.

Sibley, D.F., and Gregg, J.M. 1987. Classification of dolomite rock textures. Journal of Sedimentary Petrology, 57: 967-975.

Sweet, W.C., and Bergstrom, S.M., 1974. Provincialism exhibited by Ordovician conodont faunas. In Paleogeographic Provinces and Provinciality. Edited by C. A. Ross. Special Publication Society Economic Paleontological Mineralogy, 21: 189-202.

Thayer, C. W. 1975. Morphologic adaptations of benthic invertebrates to soft substrata: Journal of Marine Research, 33: 177-189.

Titus, R. 1988. Facies of the Trenton Group of New York. In The Trenton Group (Upper Ordovician Series) of Eastern North American. Edited by Keith, B.D. American Association of Petroleum Geologists Studies in Geology, 29: 77-86.

Tucker, M. E. 1981. Sedimentary Petrology: An Introduction to the Origin of Sedimentary Rocks. $2^{\text {nd }}$ Edition. Blackwell Scientific Publication, Oxford. pp. 260.

Tucker, M.E., and Wright, V.P. 1990. Carbonate Sedimentology. Blackwell Scientific, London, pp. 482. 
Vasconcelos, C., Mckenzie, J.A., Warthmann, R., and Bernasconi, S.M. 2005. Calibration of the $\delta^{18} \mathrm{O}$ paleothermometer for dolomite precipitated in microbial cultures and natural environments. Geology, 33: 317-320.

Wanless, H.R. 1979. Limestone response to stress: pressure solution and dolomitization. Journal of Sedimentary Petrology, 49: 445-454.

Weedon, G.P. 1985a. Paleoclimatic information from ancient pelagic and hemipelagic cyclic sediments: Terra Cognita, 5: 110.

Weedon, G.P. 1985b. Hemipelagic shelf sedimentation and climatic cycles: The basal Jurassic (Blue Lias) of South Britain, Earth and Planetary Science Letters, 78: 321-335.

Williams, D.A. 1991. Paleozoic geology of Ottawa-St. Lawerence Lowlands, southern Ontario. Ontario Geological Survey, Open File Report 5770.

Wilson, A.E. 1932. Notes on the Pamelia Member of the Black River Formation of the Ottawa Valley. American Journal of Science, 223: 135-146.

Wilson, A.E. 1946.Geology of the Ottawa-St. Lawrence lowland, Ontario and Quebec. Geological Survey of Canada Memoir 241, Ottawa, Canada, pp. 66.

Wilson, A. E. 1946a.Geology of the Ottawa- St. Lawrence Lowlands. Geological Survey of Canada Memoir 246. 
Wilson, A.E. 1946b.Brachiopoda of the Ottawa Formation of the Ottawa - St. Lawrence Lowland. Geological Survey of Canada Bulletin, 8:149.

Wilson, A. E. 1946c. Brachiopod of the Ottawa Formation of the Ottawa-St Lawrence; Geological Survey of Canada, Bulletin, 8: 61 .

Wray, J. L. 1977. Calcareous algae. Elsevier Scientific Publishing Company, Amsterdam, Oxford, New York. 


\section{APPENDICES}

Appendix I: New stratigraphic nomenclature

Williams (1991) divided the Lindsay Formation into two members; a lower "unnamed" member and an upper Eastview Member. The lower "unnamed" member is herein called the Nepean Point Member.

\section{Nepean Point Member}

\section{Lithologic character}

The Formation includes the grey, highly bioturbated, nodular, fine to coarse grained, thin to thick, highly fossiliferous limestone beds with very thin discontinuous beds and laminae of calcareous shale (Figure 28).

\section{Formation stratotype}

The formation is named for the remarkable exposure in the City of Ottawa, below the National Art Gallery at the Nepean Point along the Ottawa River (445430 m E; 5030887 $\mathrm{m} \mathrm{N}$ : Appendix II). It accessible by car just before the alexandra bridge. A general stratigraphic log is given in the Appendix III.

\section{Boundaries}

The formation overlies gradationally the Verulam Formation and underlies with apparent conformity deep-water shale of the Billings Formation. 
Characteristic fossils

The predominant fossils include crinoids, bryozoans, brachiopods, bivalves, gastropods, trilobites calcareous green algae (Dasycladacean), Girvanella. Biostratigraphy based on conodonts was imported into the local area from adjacent regions (Barnes et al. 1981), and macrofauna were used to establish biostratigraphic zones (Wilson 1946).

\section{Thickness}

The formation stratotype is $\sim 13.5 \mathrm{~m}$ thick.

Geologic Age

Available biostratigraphy (macrofauna and conodonts) establish an Upper Ordovician, Edenian ( 453 Ma) age.

\section{Correlation}

In southcentral Ontario, this unit is stratigraphically equivalent to the Lindsay Formation, based on conodont biostratigraphy. The Nepean Point Member is equivalent in age to the Tetreauville Formation in Quebec and the Tetreauville Formation in New York State. 
Page Facing 104

Figure 28. Photograph showing nodular, bioturbated, and fine to coarse-grained limestone with very thin laminae of calcareous shale of the Nepean Point Member at the National Art Gallery (Locality C). Measuring stick is $1 \mathrm{~m}$ long. 


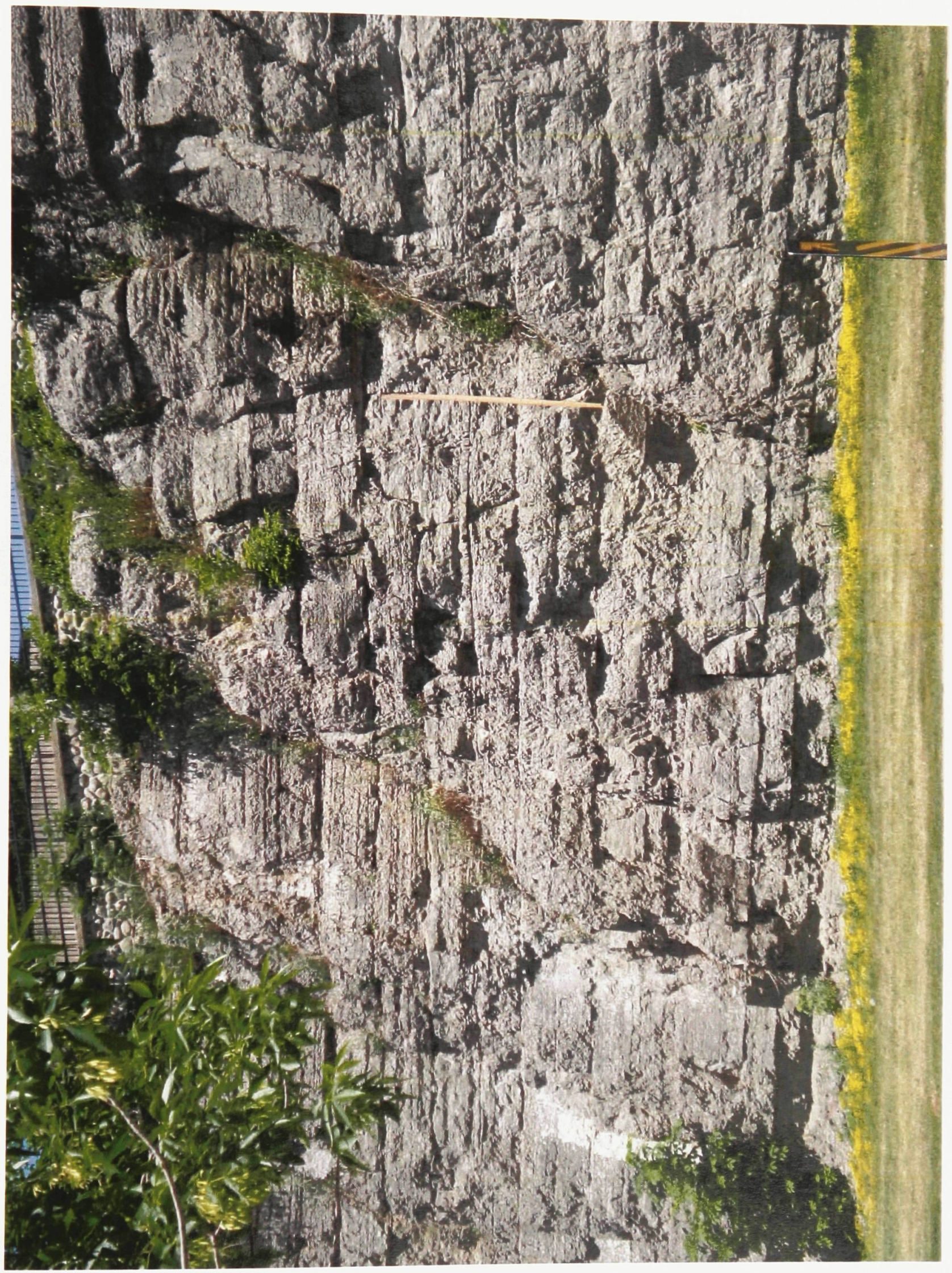


Appendix II: Study locations

\begin{tabular}{|c|c|c|}
\hline Location name & Easting (m) & Northing (m) \\
\hline 1. Bowmanville Core I & 685350 & 4868550 \\
\hline 2. Bowmanville Core II & 687000 & 4863300 \\
\hline 3. National Gallery & 445430 & 5030887 \\
\hline 4. Mint section & 445261 & 5031151 \\
\hline 5. Billings Bridge Core & 447360 & 5025840 \\
\hline 6. Aviation Parkway & 449300 & 5032050 \\
\hline 7. Russell Core & 469400 & 5017600 \\
\hline 8. Canaan Quarry & 477550 & 5033200 \\
\hline 9. Navan Quarry & 469750 & 5031500 \\
\hline 10. St. Isidore Quarry & 508000 & 5022150 \\
\hline 11. Richier Quarry & 494875 & 5012780 \\
\hline 12. Apple Hill Quarry & 517760 & 5002400 \\
\hline
\end{tabular}




\section{Appendix III: Stratigraphic Sections}

The legend applies to the stratigraphic sections in this appendix

\section{Bioclast types}

$\vdash \quad$ Skeletal fragments

解 Crinoids

(a) Gastropods

$\nabla \quad$ Brachiopods

D Bivalves

又 Trilobites

$\Sigma \square$ Bryozoans

$\ll$ Orthocones
Non-skeletal grains

$\bigcirc$ Lithoclasts

\section{Lithology}

M - Mudstone

W - W ackestone

P - Packstone

G - Grainstone

R - Rudstone

FL- Floats tone

- Shale interbeds

— M, W, P, G, R, FL interbeds
Physical Structures /

\section{Ichinofossils}

- Nodules

Skolithos (Vertical burrows)

$\$$ Bioturbation

$\curvearrowright$ Shaly partings

$=$ Planar laminations 


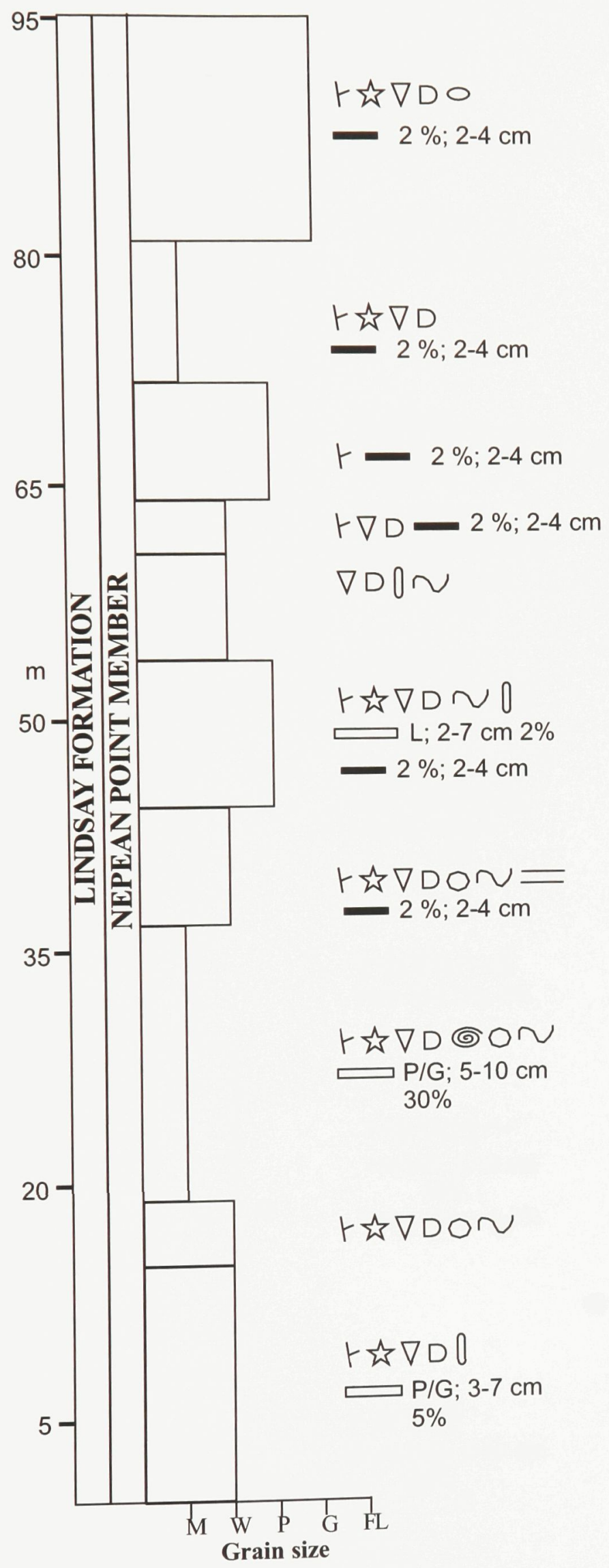

Location A BOWMANVILLE CORE I 


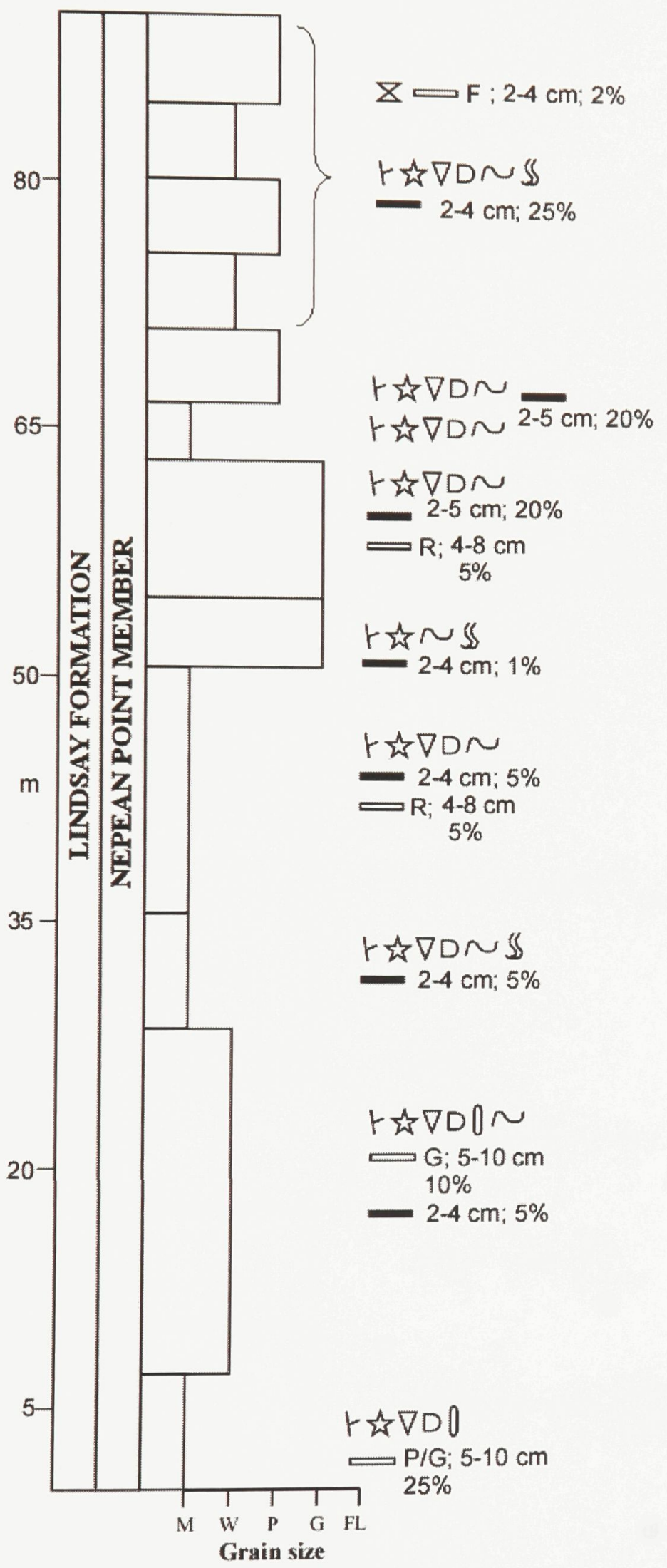

Location B

BOWMANVILLE CORE II 


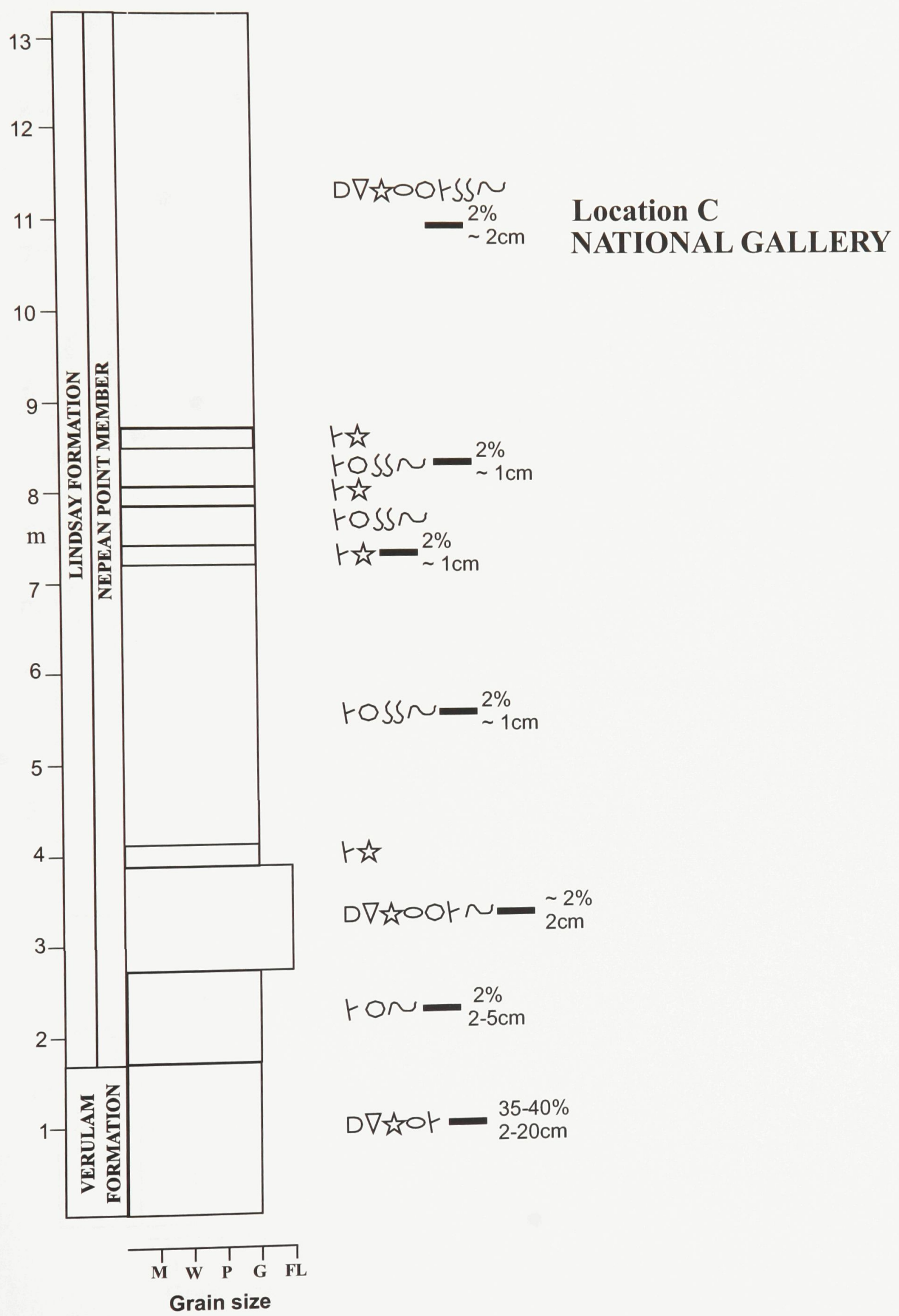




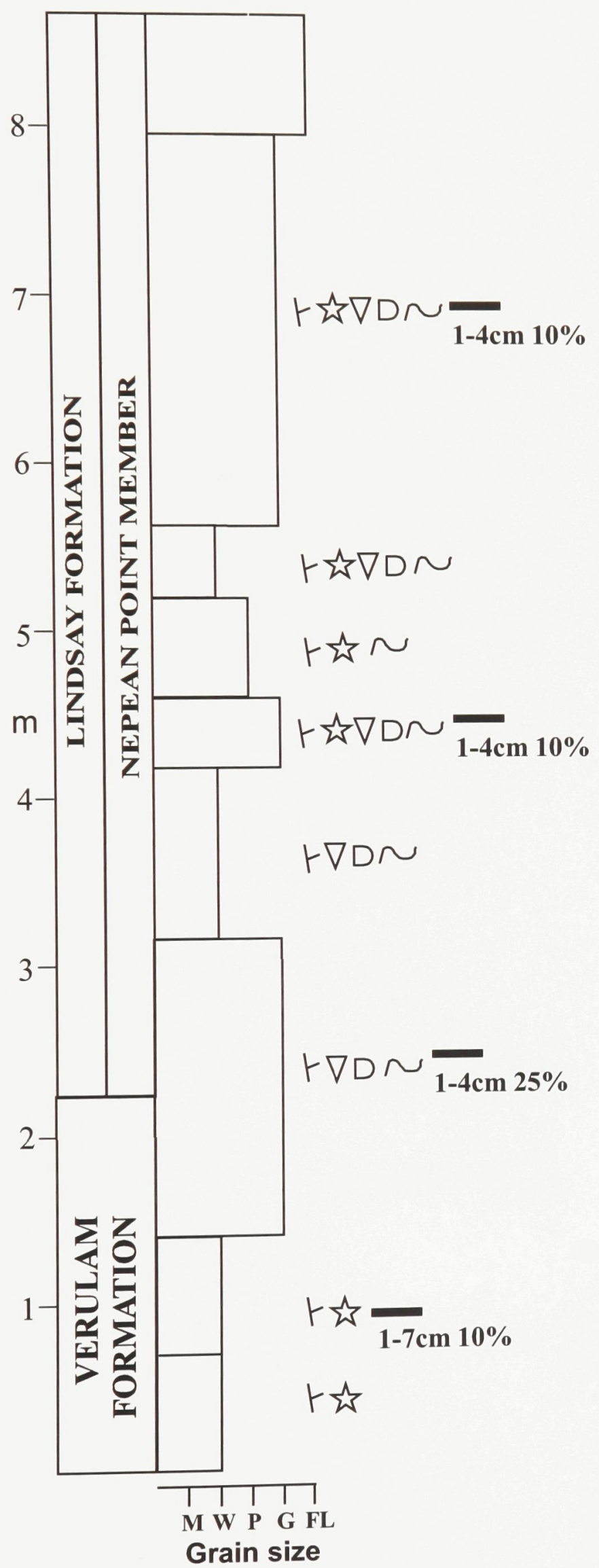

\section{Location D MINT SECTION}




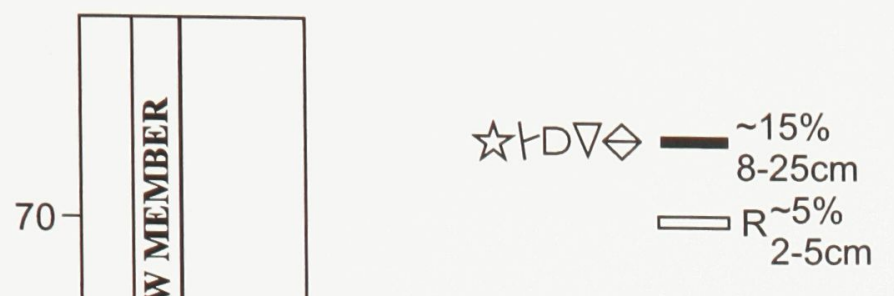

Location E BILLINGS BRIDGE

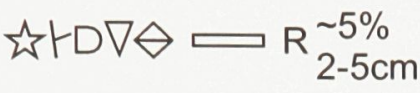

남ㅁㅇ

虫 $\theta$ HD $\nabla \circ \sim$

촌ㅁㅇ $-\begin{gathered}-10 \% \\ 2-4 \mathrm{~cm}\end{gathered}$

¿남 $=\begin{aligned} & 20 \% \\ & 2-12 \mathrm{~cm}\end{aligned}$

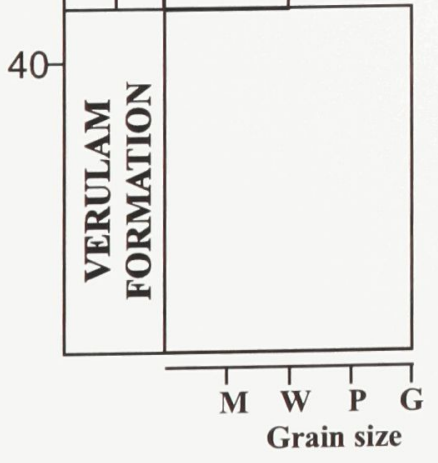

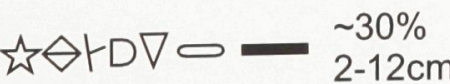




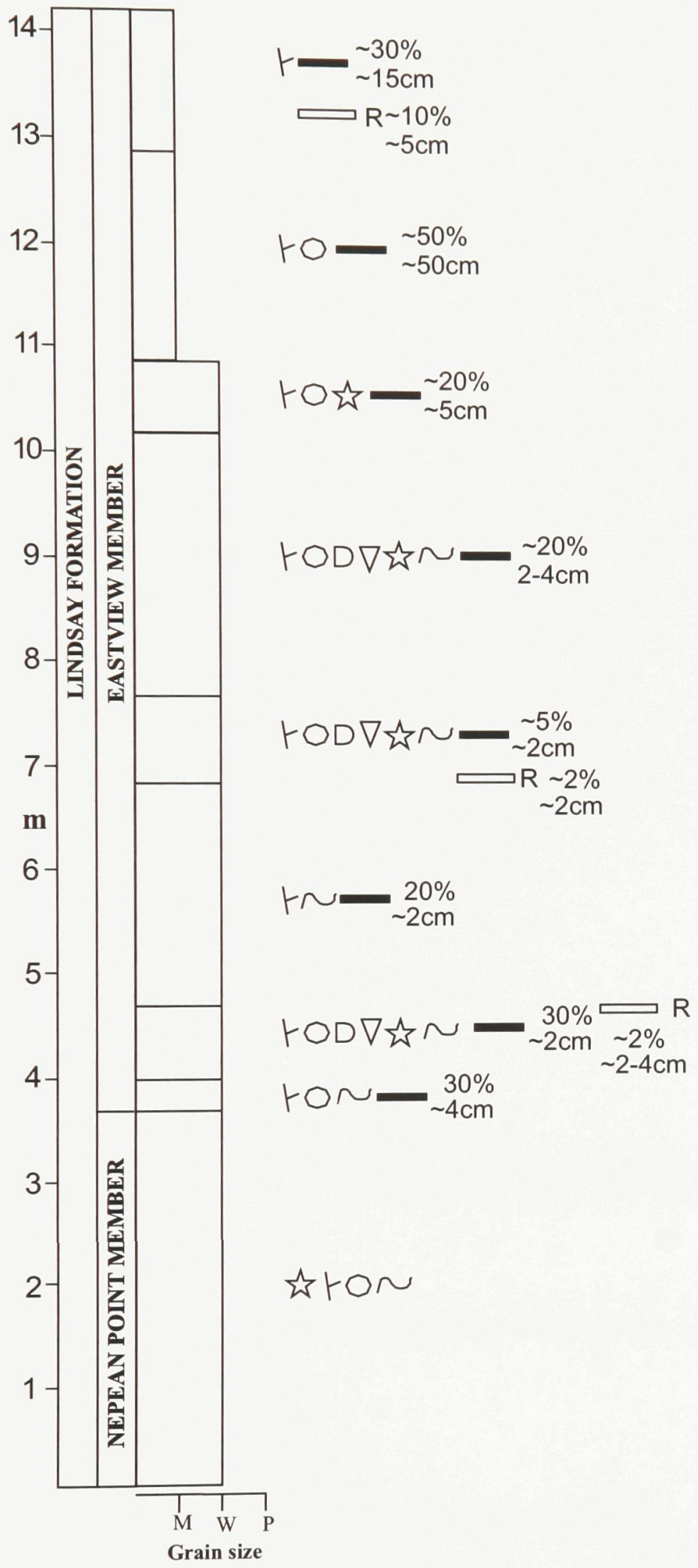

\section{Location F} AVIATION PARKWAY 


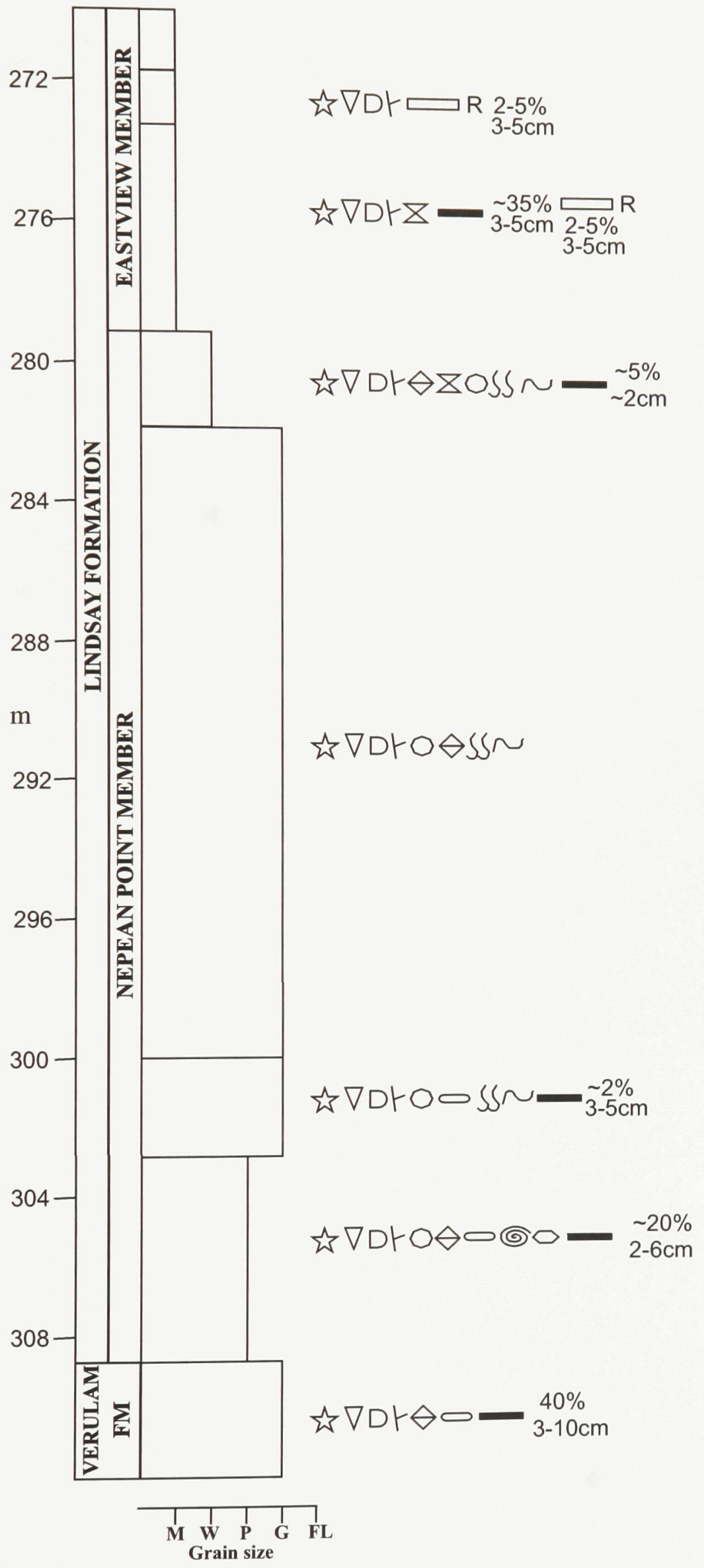

Location $\mathbf{G}$ RUSSELL CORE 


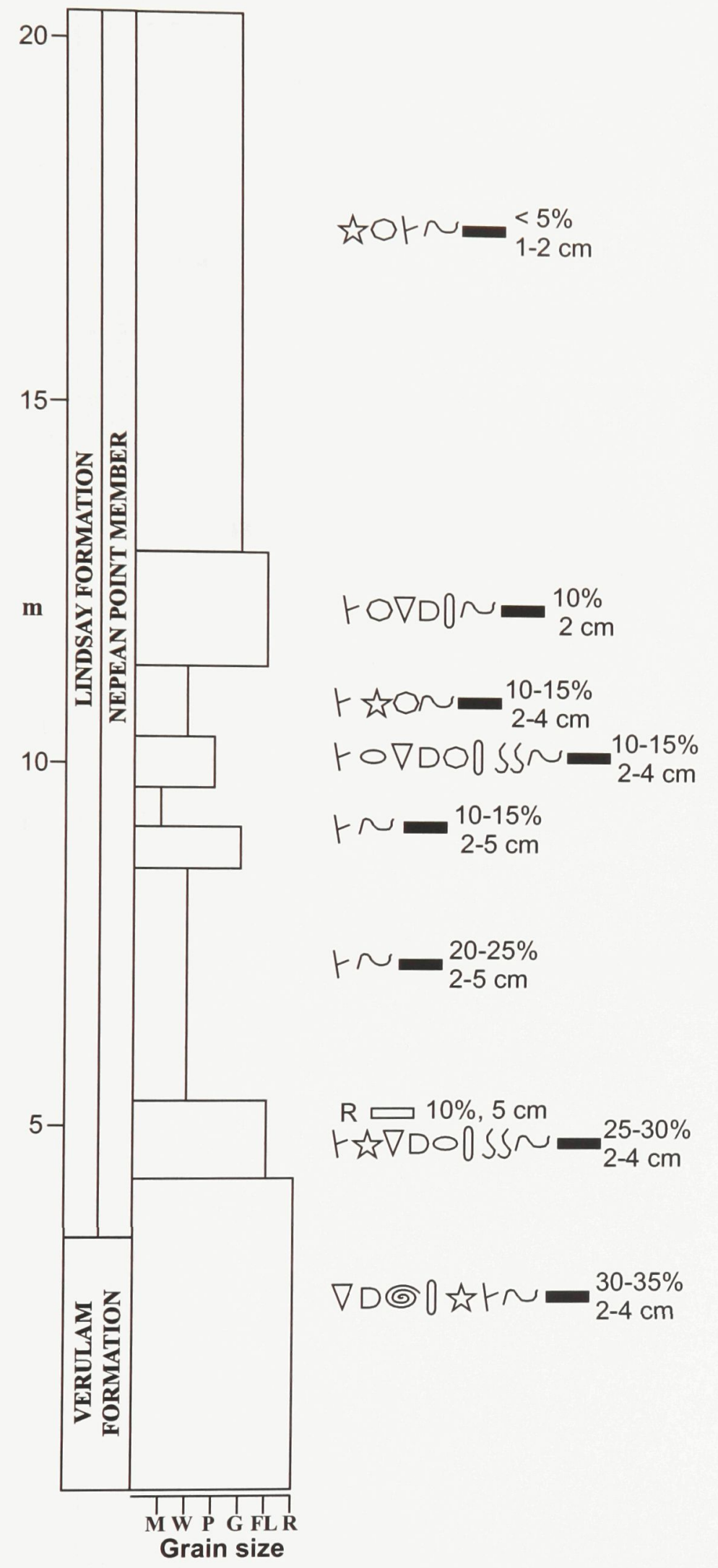

Location $\mathbf{H}$ CANAAN QUARRY 


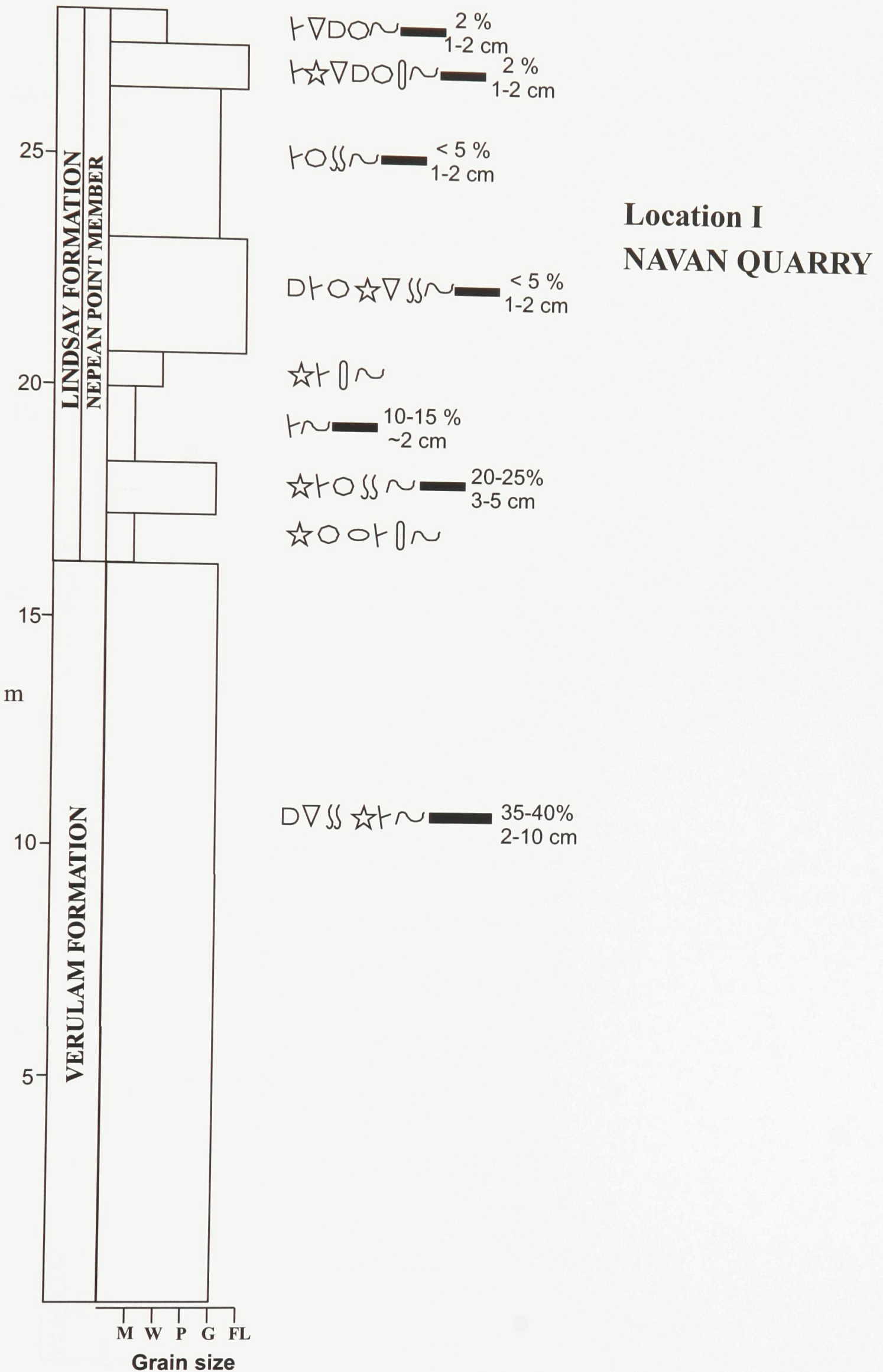




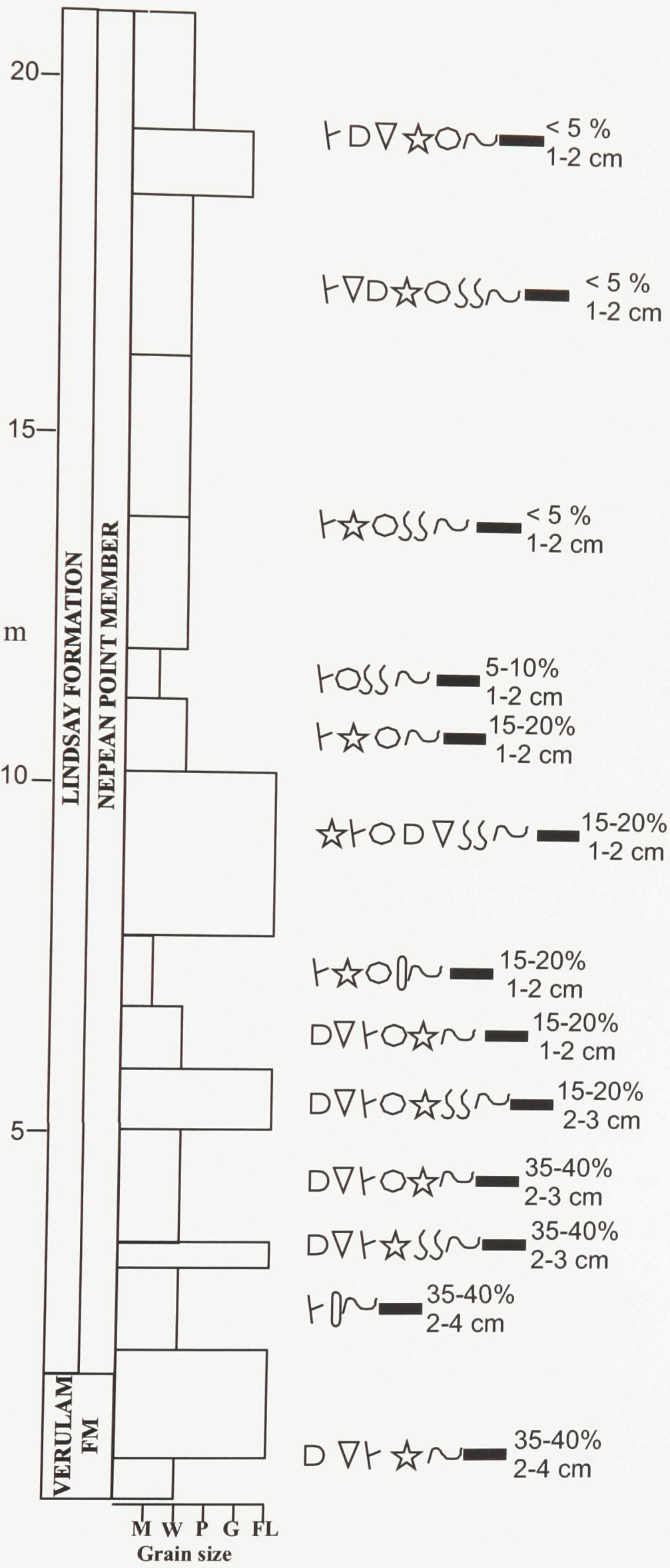

Location J

ST. ISIDORE QUARRY

ト公OSS $\sim-\begin{array}{r}<5 \% \\ 1-2 \mathrm{~cm}\end{array}$

HOSS $\sim \begin{aligned} & 5-10 \% \\ & 1-2 \mathrm{~cm}\end{aligned}$

上尔次 $15-20 \%$

幽 


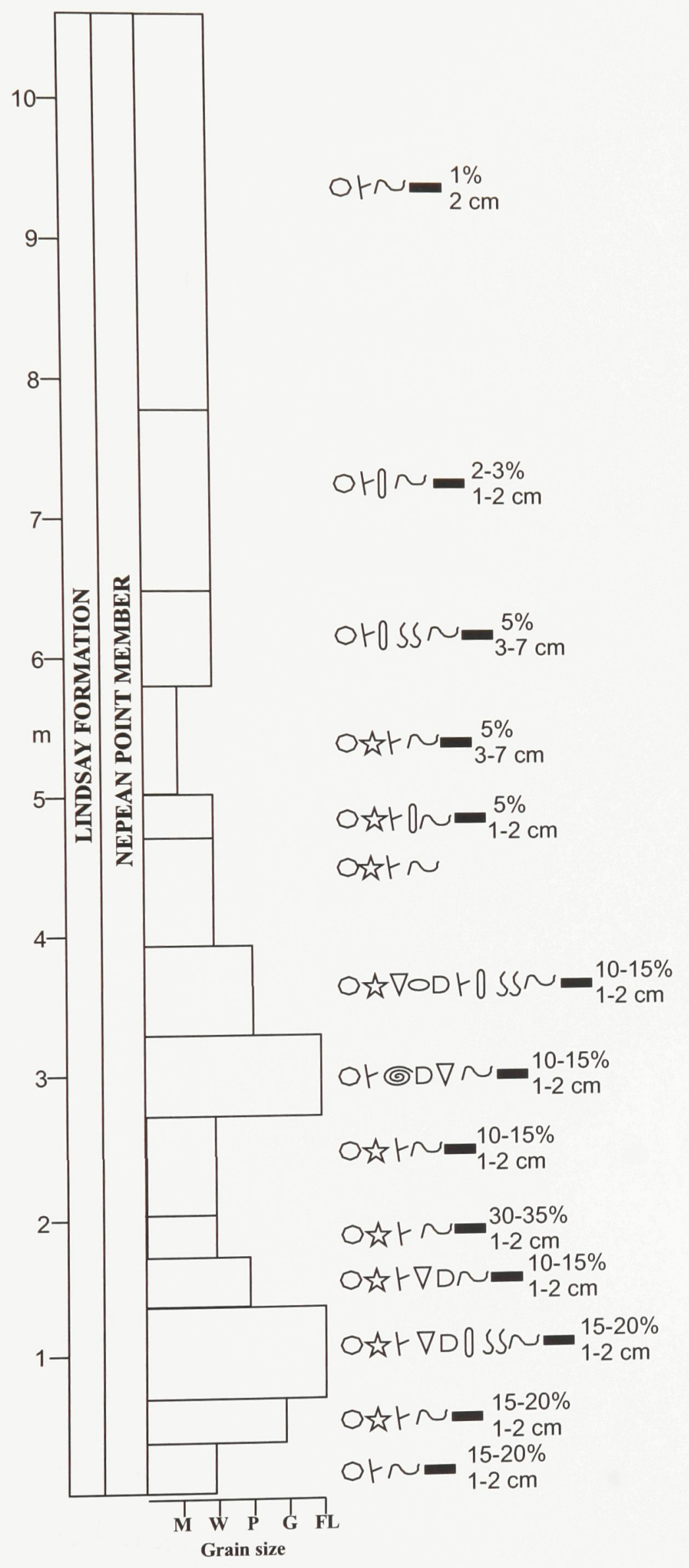

\section{Location K RICHIER QUARRY}




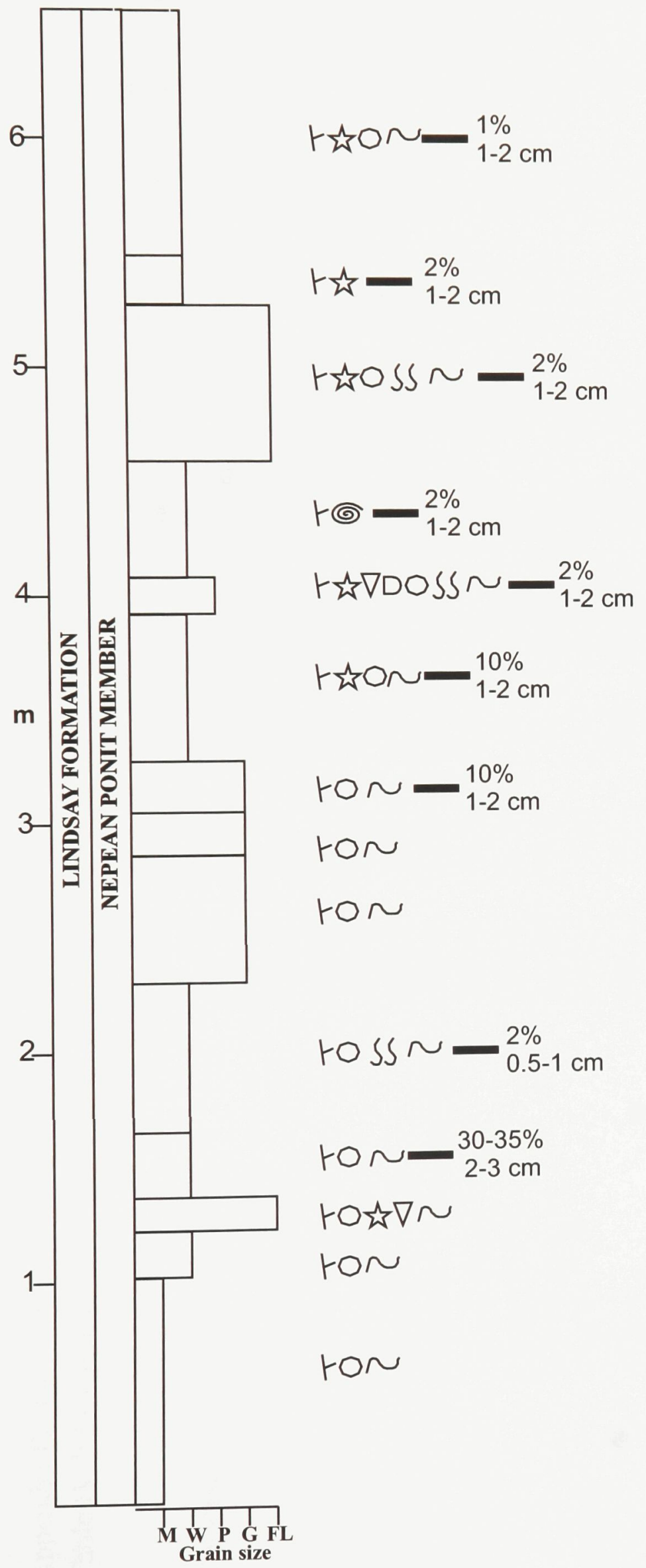

Location L

APPLE HILL QUARRY 


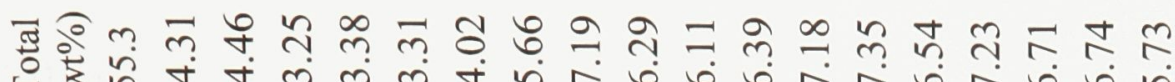

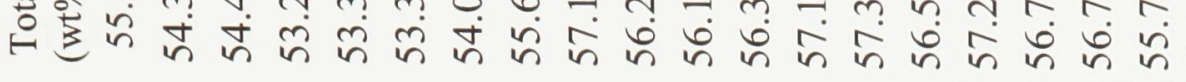

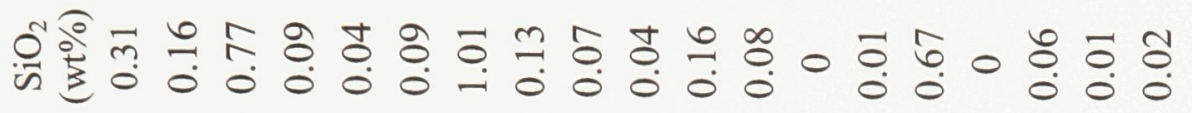

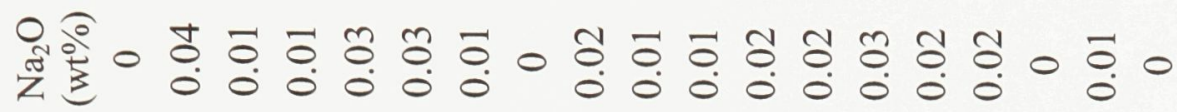

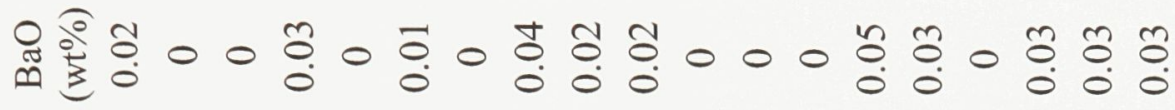

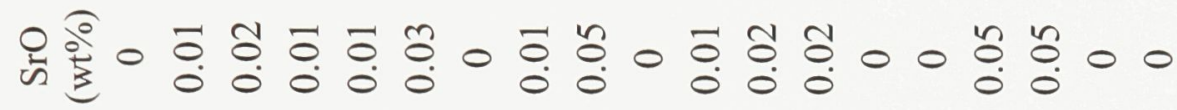

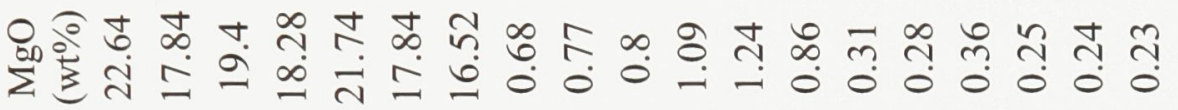

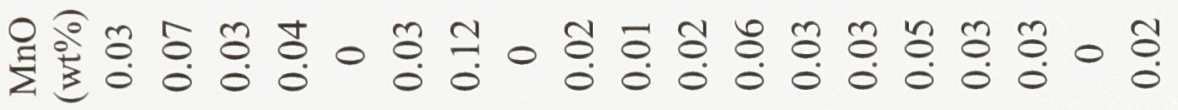

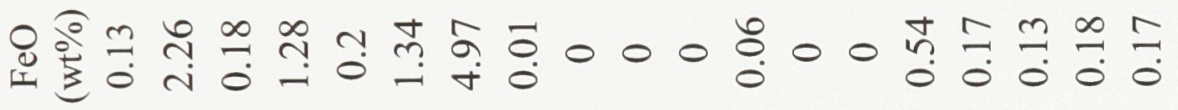

Оᄋำ

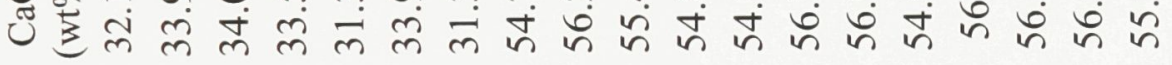

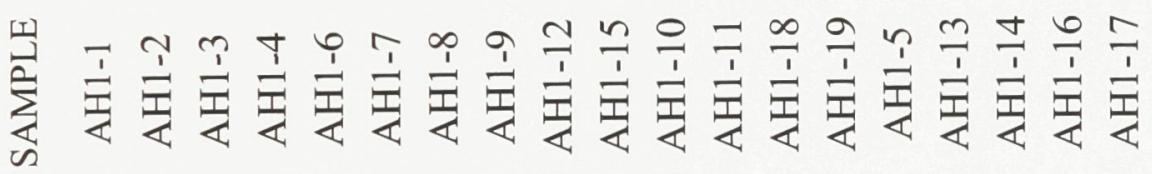
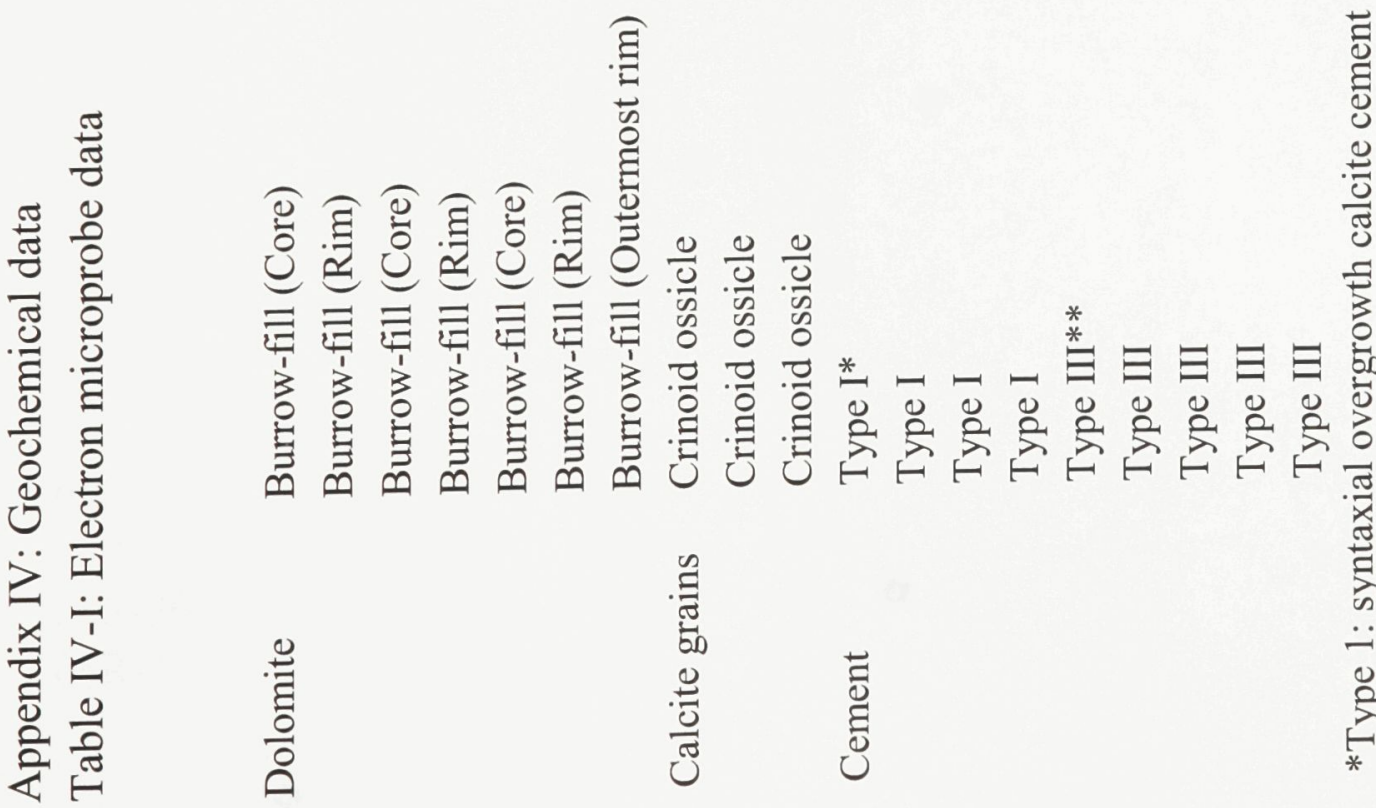

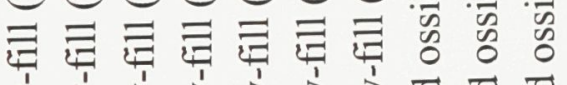

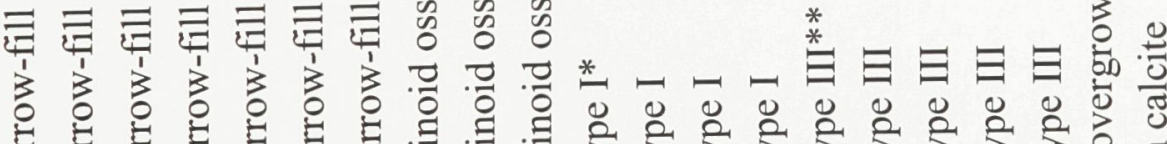

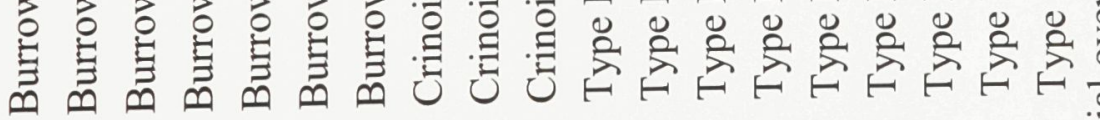

产

$\frac{\stackrel{0}{.}}{\frac{0}{0}}$

苞

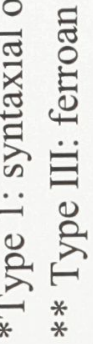


Table IV-II: $\delta^{18} \mathrm{O} \%$ and $\delta^{13} \mathrm{C}$ values of samples from the micrite facies of the Lindsay Formation in the Russell Core (Location G).

\begin{tabular}{|c|c|c|c|}
\hline Sample ID & $\begin{array}{l}\text { Depth } \\
\text { (m) }\end{array}$ & $\begin{array}{c}\delta^{13} \mathrm{C} \% \\
\mathrm{VPDB}\end{array}$ & $\begin{array}{l}\delta^{18} \mathrm{O} \% \\
\text { VPDB }\end{array}$ \\
\hline $08 \mathrm{R}-1$ & 276.00 & -0.66 & -6.33 \\
\hline $08 \mathrm{R}-2$ & 276.27 & -1.23 & -7.22 \\
\hline $08 \mathrm{R}-3$ & 276.58 & -0.65 & -6.40 \\
\hline 08R-4 & 277.12 & -0.36 & -6.45 \\
\hline $08 \mathrm{R}-5$ & 277.37 & -0.38 & -6.27 \\
\hline $08 \mathrm{R}-6$ & 277.67 & 0.43 & -7.73 \\
\hline 08R-7 & 277.95 & -0.08 & -6.56 \\
\hline 08R-8 & 278.22 & -0.36 & -6.37 \\
\hline 08R-9 & 278.43 & -0.30 & -6.71 \\
\hline $08 \mathrm{R}-10$ & 278.56 & -0.21 & -6.64 \\
\hline 08R-11 & 278.83 & 0.47 & -6.37 \\
\hline $08 \mathrm{R}-12$ & 279.07 & -0.28 & -6.51 \\
\hline 08R-13 & 279.20 & -0.34 & -6.61 \\
\hline 08R-14 & 279.38 & -0.44 & -6.46 \\
\hline 08R-15 & 279.53 & -0.41 & -6.24 \\
\hline 08R-16 & 279.93 & -0.46 & -6.65 \\
\hline 08R-16 & & & \\
\hline QCDup & & -0.43 & -6.67 \\
\hline 08R-17 & 280.17 & -0.24 & -6.66 \\
\hline 08R-18 & 280.42 & -0.45 & -6.82 \\
\hline 08R-19 & 280.75 & -0.30 & -6.22 \\
\hline 08R-20 & 281.00 & -0.49 & -6.48 \\
\hline 08R-21 & 281.21 & -0.35 & -6.52 \\
\hline 08R-22 & 281.39 & -0.10 & -6.44 \\
\hline $08 \mathrm{R}-23$ & 281.76 & 0.06 & -6.64 \\
\hline $08 \mathrm{R}-24$ & 282.15 & -0.36 & -8.14 \\
\hline $08 \mathrm{R}-25$ & 282.34 & -0.16 & -7.08 \\
\hline $08 \mathrm{R}-26$ & 282.55 & -0.20 & -6.36 \\
\hline 08R-26 & & & \\
\hline QCDup & & -0.18 & -6.39 \\
\hline 08R-27 & 283.11 & 0.01 & -7.43 \\
\hline 08R-28 & 283.36 & -0.02 & -6.70 \\
\hline 08R-29 & 283.77 & 0.06 & -6.6 \\
\hline 08R-30 & 284.38 & -0.28 & -6.9 \\
\hline 08R-31 & 284.99 & -0.42 & -7 \\
\hline
\end{tabular}




$\begin{array}{llrl}\text { 08R-32 } & 285.50 & -0.59 & -7.80 \\ \text { 08R-33 } & 286.03 & -0.33 & -7.27 \\ \text { 08R-34 } & 286.77 & -0.61 & -7.08 \\ \text { 08R-35 } & 287.22 & -0.13 & -6.95 \\ \text { 08R-36 } & 287.63 & -0.47 & -7.89 \\ \text { 08R-36 } & & & \\ \text { QCDup } & & -0.49 & -7.74 \\ \text { 08R-37 } & 288.29 & -0.82 & -7.30 \\ \text { 08R-38 } & 291.54 & -0.39 & -7.08 \\ \text { 08R-39 } & 294.39 & 0.16 & -6.30 \\ \text { 08R-40 } & 296.34 & -0.21 & -6.51 \\ \text { 08R-41 } & 298.75 & -0.69 & -6.66 \\ \text { 08R-42 } & 300.81 & -0.02 & -6.04 \\ \text { 08R-43 } & 304.34 & 0.05 & -6.43 \\ \text { 08R-44 } & 309.02 & -0.01 & -6.34\end{array}$


Table IV-III: Carbon and isotope values

$\delta^{18} \mathrm{O}$ and $\delta^{13} \mathrm{C}$ values of samples from the micrite facies of the Eastview Member of Lindsay Formation at the Aviation Parkway (Location F).

\begin{tabular}{|c|c|c|}
\hline $\begin{array}{l}\text { Height } \\
\text { (m) }\end{array}$ & $\begin{array}{l}\delta^{13} \mathrm{C} \% \\
\text { VPDB }\end{array}$ & $\begin{array}{l}\delta^{18} \mathrm{O} \% \\
\mathrm{VPDB}\end{array}$ \\
\hline 2 & -0.63 & -8.4 \\
\hline 2.85 & -0.68 & -7.36 \\
\hline 3.5 & -0.43 & -7.47 \\
\hline 4.05 & -0.64 & -6.52 \\
\hline 4.9 & -0.74 & -6.34 \\
\hline 4.9 & -0.39 & -6.8 \\
\hline 5.35 & -0.55 & -6.21 \\
\hline 5.85 & -0.18 & -6.24 \\
\hline 5.85 & -0.38 & -6.08 \\
\hline 5.95 & -0.48 & -7.18 \\
\hline 6.7 & -0.2 & -6.16 \\
\hline 6.7 & -0.08 & -5.17 \\
\hline
\end{tabular}


Table IV-IV: Carbon and isotope values

Type III: Ferroan calcite cement

Sample ID

$$
\delta^{13} \mathrm{C} \% \quad \delta^{18} \mathrm{O} \%
$$

VPDB VPDB

$\begin{array}{lcr}\text { TQ4 } & 0.34 & -5.76 \\ \text { LQ15B } & -0.63 & -7.06 \\ \text { AH10 } & -0.14 & -7.61 \\ \text { RQ6 } & -0.12 & -6.81 \\ \text { BQ10 } & -0.41 & -6.37\end{array}$

Mixture of Type II (non-ferroan) and Type III (ferroan calcite) cements

$\begin{array}{lcc}\text { TQ11B } & 0.09 & -5.85 \\ \text { LQ15A } & -0.59 & -7.16 \\ \text { AH16 } & -0.01 & -7.87 \\ \text { RQ1 } & 0.04 & -6.84 \\ \text { BQ9 } & 0.14 & -6.3 \\ \text { LQ11 } & -0.11 & -5.49 \\ \text { AH1 } & 0.02 & -6.6 \\ \text { RQ18 } & -0.08 & -4.08 \\ \text { BQ5 } & -0.26 & -3.79\end{array}$

Dolomite

LQ11

$\begin{array}{ll}-1 & -7.2\end{array}$

AH1

$-0.13-7.21$

$\mathrm{RQ} 18$

$-0.56 \quad-6.65$

BQ5

$-1.21 \quad-6.24$

